Article

\title{
Effects of Mass Selection on Husk and Cob Color in Five Purple Field Corn Populations Segregating for Purple Husks
}

\author{
Ponsawan Khamphasan ${ }^{1}$, Khomsorn Lomthaisong ${ }^{2}{ }^{-}$, Bhornchai Harakotr ${ }^{3}$, \\ Marvin Paul Scott ${ }^{4}$, Kamol Lertrat ${ }^{5}$ and Bhalang Suriharn ${ }^{1,5, *}$ \\ 1 Department of Agronomy, Faculty of Agriculture, Khon Kaen University, Khon Kaen 40002, Thailand; \\ ponsawan69@gmail.com \\ 2 Department of Biochemistry, Faculty of Science, Khon Kaen University, Khon Kaen 40002, Thailand; \\ kholom@kku.ac.th \\ 3 Department of Agricultural Technology, Faculty of Science and Technology, Thammasat University, \\ Phathum Thani 12120, Thailand; p.harakotr@gmail.com \\ 4 Corn Insects and Crop Genetics Research Unit, USDA-ARS, Ames, IA 50011, USA; Paul.Scott@ars.usda.gov \\ 5 Plant Breeding Research Center for Sustainable Agriculture, Khon Kaen 40002, Thailand; kamol9@gmail.com \\ * Correspondence: sphala@kku.ac.th; Tel.: +66-43-202-696
}

Received: 25 June 2020; Accepted: 24 July 2020; Published: 27 July 2020

\begin{abstract}
Improvement of anthocyanin levels in husks and cobs of field corn may add economic value to corn coproducts in commercial production. This study aimed to evaluate the response to four cycles of modified mass selection (MMS) for yield, agronomic traits, total anthocyanin yield (TAY), total anthocyanin content (TAC), total phenolic content (TPC) and antioxidant activity determined by 2,2-diphenyl-1-picrylhydrazyl free radical scavenging activity assay (DPPH) and trolox equivalent antioxidant capacity assay (TEAC) in corn husk and cob of five purple field corn populations. The improved populations and check varieties were evaluated at two locations for two seasons in 2017/2018. Selection cycle contributed to a large portion of the total variations for TAC, TPC, DPPH and TEAC in corn husk and cob. All tested populations showed progress for days to anthesis, TAY, TAC, TPC, DPPH and TEAC across four cycles of selection. Lack of significant correlation between agronomic traits and anthocyanin concentrations suggested the independent segregation of these traits. MMS was successfully used to develop field corn populations with improved anthocyanin, antioxidant activities and early flowering without significant yield loss. The populations with the highest selection gains for anthocyanin in husk and cob were identified. Visual selection for dark purple husks and cobs boosted anthocyanin levels and antioxidant activity in selected populations.
\end{abstract}

Keywords: maize; plant breeding; population improvement; response to selection; phytochemical

\section{Introduction}

Field corn is an important crop in the world and an excellent source of food and animal feed. The kernels provide abundant nutrients, including carbohydrates, oil and protein [1]. The diverse pigmentation of corn is due to the presence of phytochemicals such as carotenoids [1] and anthocyanins, a class of phlobaphene pigment [2]. Purple corn, in particular, is rich in anthocyanins and related traits such as total phenolic compound and antioxidant activity [3-5], and accumulation of high value compounds such as anthocyanins in specific tissues makes it possible to develop production strategies for high value chemicals using these tissues as feedstock. Anthocyanin is a natural purple pigment and an antioxidant agent [4] with human health benefits. For instance, it reduces the risk of chronic diseases such as cancer [6] and obesity [7]. Safety issues related to purple corn color (PCC), a natural 
pigment based on corn anthocyanins, were examined by a clinical study [8], and anthocyanins were suggested as promising natural colorants and supplements [9].

The color in husk and cob of corn is controlled by the pericarp color 1 gene (p1). The $\mathrm{p} 1$ gene confers phlobaphene pigmentation in female floral tissue such as corn kernel pericarp and cob glumes [10], husk, silk and tassel glume margins of the male inflorescence [11,12]. The p1 alleles vary in their tissue specific expression patterns with a two-letter suffix that refers to pericarp and cob glume coloration. For example, the P1-rr allele displays red pericarp and red cob glume, the P1-ww displays white or colorless pericarp and white cob glumes [13], the P1-wr displays white pericarp and red cob glumes [13,14], and the P1-rw displays red pericarp and white cob glumes [13,15]. Previous studies assumed that additive genetic effect was important in P1 gene expression, and the expression was stable across environments [16].

Corn growers leave a large proportion of non-grain tissues in the field after harvest. These parts, including husk and cob, are defined as corn waste. Husk and cob contribute to $20-30 \%$ of total corn residue (excluding kernel) and offers a low cost, plentiful and renewable raw material [17]. The waste was used for animal feedstock [18], biofuel or ethanol production [19] and other industrial raw materials [20]. The feeding of the anthocyanin-rich corn silage led to a reduction in aspartate aminotransferase (AST) activity and an increase in superoxide dismutase (SOD) activity in the plasma [21]. In Thailand, the improved population developed by this project is used as roughage and silage for tropical beef cattle [22]. In purple corn, the husk $[5,23]$ and cob $[5,23,24]$ had higher anthocyanin content than the kernel, based on tissue mass [2,25]. Our study used the varieties with purple husk and cob and orange kernels. If conventional breeding can be used to increase levels of pigmentation in the cob and husk, it would improve the feasibility of converting the waste tissues into feedstock for phytochemical production.

Mass selection is a method of population improvement that is based on the selection of desirable individuals in a randomly intermated population [26]. In field corn, this method has been used to enhance ear prolificacy [27] and alter maturity date [28]. Yet, the response to selection in quantitative traits is low [29]. Modified mass selection was developed from classic mass selection in which only selected plants are pollinated. It has been adopted for increasing ear prolificacy of small ear waxy corn [30], ear length [31] and yield [32] of waxy corn. In field corn, the concentrations of some phytochemicals such as oil and protein have been improved through mass selection [33], and the concentrations of methionine [34], oil and fatty acid [35], pro-vitamin A, $\beta$-carotene, $\beta$-cryptoxanthin and zeaxanthin [36] have also been improved through similar methods. However, population improvement for anthocyanin in purple corn husk and cob has not been reported. Thus, the aim of this study was to evaluate the response to four cycles of modified mass selection in five populations of purple field corn for yield, agronomic traits, total anthocyanin yield (TAY), total anthocyanin content (TAC), total phenolic content (TPC) and antioxidant activity in husk and cob determined by the 2,2-diphenyl-1-picrylhydrazyl free radical scavenging activity assay (DPPH) and the trolox equivalent antioxidant capacity assay (TEAC) method.

\section{Materials and Methods}

\subsection{Plant Materials}

The corn genotypes used as parents of the base populations consisted of two groups of field corn (Table 1). The genotypes in group 1 including Pacific339, NS3 and NSX were used as maternal parents. Pacific339 is a commercial hybrid from the Pacific company. NS3 and NSX are a commercial hybrid and an elite line, respectively, developed by Nakhon Sawan Field Crops Research Center, Department of Agriculture, Nakhon Sawan, Thailand. All genotypes in this group have orange kernels, green husks and white cobs. 
Table 1. Brief information of field corn genotypes used in this study.

\begin{tabular}{cccccc}
\hline \multirow{2}{*}{ Line } & \multirow{2}{*}{ Pedigree } & \multicolumn{3}{c}{ Color } & Source \\
\cline { 3 - 6 } & & Kernel & Husk & Cob & \\
\cline { 3 - 6 } Female & & orange & green & white & PS \\
PSX & & orange & green & white & NSFCRC \\
NS3 & & orange & green & white & NSFCRC \\
\hline Male & & & & & \\
PF1 & AB/PF & purple & purple & purple & PBRCSA \\
PF2 & TB/KND10//PF & white & purple & purple & PBRCSA \\
PF3 & TL/PF//KND10 & yellow & purple & purple & PBRCSA \\
PF4 & DKA/PF//KND & purple & purple & purple & PBRCSA \\
PF5 & WSTS/PF//KND & white & purple & purple & PBRCSA \\
\hline
\end{tabular}

AB- Khao-Niew-Dum AB; PF- Purple field corn; TB—Tian-Black (Tian-Dum); KND10—Khao-Niew-Dum 10; TL-Tian-Line; DKA-Dok-Koon A; KND—Khao-Niew-Dum; WSTS-White sweeter; PS— Pacific Seeds (Thai) Ltd., Saraburi, Thailand; NSFCRC - Nakhon Sawan Field Crops Research Center, Nakhon Sawan, Thailand; PBRCSA_Plant Breeding Research Center for Sustainable Agriculture, Khon Kaen, Thailand.

Five near inbred lines in group 2 consisting of PF1, PF2, PF3, PF4 and PF5 were used as paternal parents. These lines were improved by the Vegetable Corn Breeding Project, Plant Breeding Research Center for Sustainable Agriculture, Khon Kaen University, Khon Kaen, Thailand. These lines were chosen because of their high anthocyanin concentration and antioxidant activity [5].

Five base populations (C0) of purple field corn including population A (Pacific339 $\times$ PF1), population B (Pacific339 $\times$ PF2), population C $(\mathrm{NSX} \times \mathrm{PF} 3)$, population $\mathrm{D}(\mathrm{NSX} \times \mathrm{PF} 4)$ and population $\mathrm{E}(\mathrm{NS} 3 \times$ PF5) were generated by intercrossing designated orange field corn varieties as maternal parents and purple field corn lines as paternal parents in the dry season of 2014. Each population (A-E) was randomly intermated. The pollen from each population was bulked and used to pollinate all ears in the population in the rainy season 2015 and all pollinated ears in each population were harvested. The F2 generations of the five populations (A-E) were defined as the base populations (C0) for the study.

\subsection{Population Improvement}

The segregating populations ( $\mathrm{C} 0$ ) for cob and husk color contained higher number of pigmented husks and cobs than unpigmented husks and cobs. The five base populations ( $\mathrm{C} 0)$ were further improved through modified mass selection method in the dry season of 2015 to increase husk and cob pigmentation while retaining orange kernels coloration. Modified mass selection was carried out for four consecutive cycles (Figure 1). Phenotypic selection from the $\mathrm{C} 0$ generation to the $\mathrm{C} 4$ generation was performed at four stages: 1 . Selection for good stand and disease-free plants with dark green leaves at pre-reproductive stage; 2 . Selection for big purple tassels and early flowering at reproductive stage; 3. Selection for large ears with purple husks at mature stage; 4 . Selection for wild-type corn endosperm at dry kernel stage because some populations contained the $w \times 1$ allele using potassium iodide (KI) in orange kernels and purple cobs. The selection intensity was 5 to 10 percent in each cycle and the remaining seeds were stored in cool conditions for further evaluation. Modified mass selection for four cycles was completed in the rainy season 2017. 
Base populations (C0)

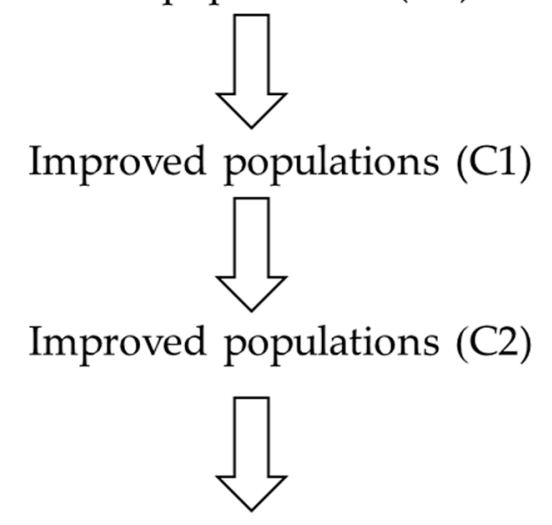

Improved populations (C3)

Improved populations (C4)

Figure 1. Schematic diagram for population improvement of five purple field corn populations through modified mass selection emphasizing purple husk and cob and orange kernels for four cycles in 2015 to 2017.

\subsection{Field Experiment}

Five cycles (C0-C4) of five populations (A to E) (25 entries) and three check varieties (KND, KGW and P339) were evaluated in a randomized complete block design (RCBD) with three replications in the dry season (November 2017 to February 2018) and in the rainy season (May to August 2018) at two locations at the Agronomy Field Crop Research Station, Faculty of Agriculture, Khon Kaen University and a farmer's field in the Uthai Thani Province, Thailand. Irrigation was available at both locations. The climate profile and soil type of these experimental sites were different (Table 2 and Figure A1). The plot size was a 5-m-long four-row plot with a spacing of $0.8 \mathrm{~m}$ between rows and $0.25 \mathrm{~m}$ between plants within rows. Recommended agricultural practices for commercial corn production were followed.

Table 2. Description of four experimental sites in the study.

\begin{tabular}{|c|c|c|c|c|c|c|c|}
\hline Environment & Location & Season & Latitude & Longitude & Altitude (m) & Soil Texture & $\begin{array}{c}\text { Average } \\
\text { Temperature }\left({ }^{\circ} \mathrm{C}\right)\end{array}$ \\
\hline E1 & \multirow{2}{*}{$\begin{array}{l}\text { Khon } \\
\text { Kaen }\end{array}$} & Dry $2017 / 2018$ & \multirow{2}{*}{$16^{\circ} 28^{\prime} 11.24^{\prime \prime} \mathrm{N}$} & \multirow{2}{*}{$102^{\circ} 48^{\prime} 49.46 \mathrm{E}$} & \multirow{2}{*}{120} & \multirow{2}{*}{ Sandy loam } & 19.1 \\
\hline E2 & & Rainy 2018 & & & & & 27.7 \\
\hline E3 & \multirow{2}{*}{$\begin{array}{l}\text { Uthai } \\
\text { Thani }\end{array}$} & Dry 2017/2018 & \multirow{2}{*}{$15^{\circ} 22^{\prime} 57.77^{\prime \prime} \mathrm{N}$} & \multirow{2}{*}{$100^{\circ} 4^{\prime} 42.54^{\prime \prime} \mathrm{E}$} & \multirow{2}{*}{20} & \multirow{2}{*}{ Clay loam } & 26.6 \\
\hline E4 & & Rainy 2018 & & & & & 29.7 \\
\hline
\end{tabular}

\subsection{Sample Preparation and Extraction}

Ten randomly selected corn ears from each plot were harvested at physiological maturity (40 days after pollination) and oven-dried at $40{ }^{\circ} \mathrm{C}$ for $48 \mathrm{~h}$. The anthocyanins were extracted as described with minor modifications $[37,38]$. The harvested tissues from each plot were pooled into husk and cob pools and ground into powder and the powdered samples of approximately $2 \mathrm{~g}$ were loaded into $100 \mathrm{~mL}$ flasks containing $20 \mathrm{~mL}$ of $100 \%$ methanol. The flasks were shaken on a multi-stirrer at $200 \mathrm{rpm}$ for $1 \mathrm{~h}$ at room temperature. The samples were further filtered through Whatman \#1 filter paper. After filtration, the retentates were loaded again into $100 \mathrm{~mL}$ flasks containing $20 \mathrm{~mL}$ of $100 \%$ methanol and shaken on a platform shaker for $1 \mathrm{~h}$ and filtered through Whatman \#1 filter paper. The filtrates 
were combined and evaporated in a rotary evaporator to reduce the volume from $40 \mathrm{~mL}$ to $10 \mathrm{~mL}$ at $40^{\circ} \mathrm{C}$ and stored at $-20^{\circ} \mathrm{C}$ in the dark.

\subsubsection{Determination of Total Anthocyanin Content (TAC)}

Total monomeric anthocyanin content in each sample was estimated using the $\mathrm{pH}$ differential method [39]. A UV-Vis spectrophotometer (GENESYS 10S, Thermo Scientific, Waltham, MA, USA) was used to measure the absorbance at 510 and $700 \mathrm{~nm}$ in a cuvette with a $1 \mathrm{~cm}$ path length. Total monomeric anthocyanin concentration (TAC) was expressed as milligrams of cyanidin-3-glucoside equivalents per $100 \mathrm{~g}$ dry weight (mg CGE/100 g DW) of samples, anthocyanin pigment (cyanidin-3-glucoside equivalents, $\mathrm{mg} / \mathrm{L}$ ) calculated using the following equation:

$$
\mathrm{TAC}=\frac{\mathrm{A} \times \mathrm{MW} \times \mathrm{DF} \times 10^{3}}{\varepsilon \times 1},
$$

where $\mathrm{A}=(\mathrm{A} 510 \mathrm{~nm}-\mathrm{A} 700 \mathrm{~nm}) \mathrm{pH} 1.0-(\mathrm{A} 510 \mathrm{~nm}-\mathrm{A} 700 \mathrm{~nm}) \mathrm{pH} 4.5 ; \mathrm{MW}$ (molecular weight) $=449.2 \mathrm{~g} / \mathrm{mol}$ for cyanidin-3-glucoside (cyd-3-glu); $\mathrm{DF}=$ dilution factor; $1=$ pathlength in $\mathrm{cm} ; \varepsilon=26,900$ molar extinction coefficient, in $\mathrm{L} \times \mathrm{mol}^{-1} \times \mathrm{cm}^{-1}$, for cyd-3-glu and $10^{3}=$ factor for conversion from $\mathrm{g}$ to $\mathrm{mg}$. Then, TAC was converted into TAY by following this equation:

$$
\mathrm{TAY}=\frac{\mathrm{TAC}(\mathrm{mg} \text { CGE } / 100 \mathrm{~g} \text { DW })}{\text { Dry matter yield }(\mathrm{kg} / \mathrm{ha})}
$$

\subsubsection{Determination of Total Phenolic Content (TPC)}

Total phenolic content in each sample was determined according to Folin-Ciocâlteu's phenol reagent (FC reagent) procedure with minor modification [40]. The reaction was prepared by mixing $0.5 \mathrm{~mL}$ methanol extract, $2.5 \mathrm{~mL}$ water and $0.5 \mathrm{~mL}$ FC reagent, which was pre-diluted from $2 \mathrm{M}$ to $1 \mathrm{M}$ with distilled water. The mixture was set aside at room temperature for eight minutes and $1.5 \mathrm{~mL}$ $\mathrm{Na}_{2} \mathrm{CO}_{3}$ solution was added. After $120 \mathrm{~min}$ at room temperature, the absorbance of the mixture was read at $765 \mathrm{~nm}$ using a UV-Visible spectrophotometer. A series of gallic acid solutions (10-100 mg/L) was used as a reference standard. The total phenolic content (TPC) was expressed as mg gallic acid equivalents/100 g dry weight of samples (mg GAE/100 g DW).

\subsubsection{Determination of Antioxidant Assay}

The 2,2-diphenyl-1-picrylhydrazyl free radical scavenging activity assay (DPPH) was determined by measuring the capacity of bleaching a black colored methanol solution of DPPH radicals as reported by [40]. Briefly, the reaction for each sample was prepared by mixing $4.5 \mathrm{~mL}$ of the methanolic solution of DPPH $(0.065 \mathrm{mM})$ and $0.5 \mathrm{~mL}$ of a sample extract. The reaction was conducted at room temperature for $30 \mathrm{~min}$ before the absorbance was recorded at $517 \mathrm{~nm}$. A series of Trolox solutions $(100-1000 \mu \mathrm{M})$ was used as a reference standard. Values were expressed as millimoles Trolox equivalents (TE) per $100 \mathrm{~g}$ of dry weight (mmol TE/100 g DW).

The trolox equivalent antioxidant capacity assay (TEAC) for each sample was determined according to the method described [40] with minor modifications. Briefly, 2,2'-azinobis(3ethylbenzothiazoline-6-sulfonic acid $\left(\mathrm{ABTS}^{+}\right.$) radical cations were generated by a reaction of $7 \mathrm{mmol} / \mathrm{L}$ $\mathrm{ABTS}^{+}$and $2.45 \mathrm{mmol} / \mathrm{L}$ potassium persulfate. The reaction mixture was left in the dark at room temperature for $16-24 \mathrm{~h}$ before use and the mixture were used within 2 days. The ABTS ${ }^{+}$solution was diluted with methanol to an absorbance of $0.700 \pm 0.050$ at $734 \mathrm{~nm}$ ). Fifty microliters of the diluted extract were mixed with $2.0 \mathrm{~mL}$ of diluted $\mathrm{ABTS}^{+}$solution for $6 \mathrm{~min}$ at room temperature and the absorbance was immediately recorded at $734 \mathrm{~nm}$. A series of Trolox solutions (100-1000 $\mu \mathrm{M})$ was used as a reference standard. The value was expressed as millimoles Trolox equivalents (TE) per $100 \mathrm{~g}$ of dry weight (mmol TE/100 g DW). 


\subsection{Statistical Analysis}

The data of 25 entries ( 5 populations and 5 cycles) tested at four environments were analyzed for yield, agronomic traits, total anthocyanin yield (TAY), total anthocyanin content (TAC), total phenolic content (TPC) and antioxidant activity determined by the DPPH and TEAC methods. Analysis of variance (ANOVA) was performed separately for each location and error variances were tested for homogeneity. The data with variance homogeneity were further combined in combined ANOVA. The statistical model for the analysis is as follows [41];

$$
\mathrm{Y}_{\mathrm{ijk} \mathrm{k}}=\mu+\mathrm{B}_{\mathrm{i}}+\mathrm{E}_{\mathrm{j}}+\mathrm{P}_{\mathrm{k}}+\mathrm{C}_{\mathrm{l}}+\mathrm{EP}_{\mathrm{jk}}+\mathrm{EC}_{\mathrm{jl}}+\mathrm{PC}_{\mathrm{kl}}+\mathrm{EPC}_{\mathrm{jkl}}+\mathrm{e}_{\mathrm{ij}}+\mathrm{e}_{\mathrm{ijk}}+\mathrm{e}_{\mathrm{ijkl}}
$$

where $Y_{\mathrm{ijk}}$ is the observed value of each measurement, $\mu$ is mean of all observations in the experiment, $B_{i}$ is the effect of the ith block, $E_{j}$ is the effect of the jth environment, $P_{k}$ is the effect of the kth population (A-E), $\mathrm{C}_{1}$ is the effect of the lth cycle $(\mathrm{C} 0-\mathrm{C} 4)$ effects, $\mathrm{EP}_{\mathrm{jk}}$ is interaction between environment and population effects, $\mathrm{EC}_{\mathrm{jl}}$ is interaction between environment and cycle effects, $\mathrm{PC}_{\mathrm{kl}}$ is interaction between population and cycle effects, $\mathrm{EPC}_{\mathrm{jkl}}$ is interaction between environment, population and cycle effects, $\mathrm{e}_{\mathrm{ij}}$ is error of the $\mathrm{E}_{\mathrm{j}}, \mathrm{e}_{\mathrm{ijk}}$ is error of the $\mathrm{P}_{\mathrm{k}}, \mathrm{EP}_{\mathrm{jk}}$, and $\mathrm{e}_{\mathrm{ijk}}$ is error of the $\mathrm{C}_{1}, \mathrm{EC}_{\mathrm{jl}}, \mathrm{PC}_{\mathrm{kl}}$ and $\mathrm{EPC}_{\mathrm{jk}}$. Mean differences were compared by least significant difference (LSD) at 0.05-probability level.

Estimates of broad-sense heritability for the five populations in each environment were calculated by partitioning variance components of cycle mean squares to pooled variance $\left(\sigma_{E}^{2}\right)$ and genotypic variance $\left(\sigma_{G}^{2}\right)$ and then broad-sense heritability estimates $\left(h_{b}^{2}\right)$ were calculated as follows [42]:

$$
\begin{gathered}
h_{b}^{2}=\frac{\sigma_{G}^{2}}{\sigma_{P}^{2}} \\
\sigma_{P}^{2}=\sigma_{G}^{2}+\frac{\sigma_{E}^{2}}{r}
\end{gathered}
$$

where $h_{b}^{2}$ is broad sense heritability, $\sigma_{G}^{2}$ is genotypic variation, $\sigma_{P}^{2}$ is phenotypic variation and $r$ is no. of replications.

A simple linear regression analysis was analyzed to determine the response to selection. Simple linear regression analysis was calculated, and the estimates were tested for significance according to Gomez and Gomez (1984). The estimated linear regression was calculated as follows:

$$
\hat{Y}=a+b X
$$

where $\hat{Y}$ is the value of the dependent variable $(\mathrm{Y})$ that is being predicted or explained; $a$ or alpha, a constant, equals the value of $Y$ when the value of $X=0 ; b$ or beta, the coefficient of $X$, the slope of the regression line, how much $Y$ changes for each one-unit change in $X ; X$ is the value of the Independent variable $(X)$, what is predicting or explaining the value of $Y$;

Test for the significance of $b$ value was calculated as follows:

$$
\begin{gathered}
S_{y \cdot x}^{2}=\frac{\sum y^{2}-\frac{\left(\sum x y\right)^{2}}{\sum x^{2}}}{n-2}, \\
t_{b}=\frac{b}{\sqrt{\frac{S_{y \cdot x}^{2}}{\sum x^{2}}}}
\end{gathered}
$$

where $S_{y x}{ }^{2}$ is the residual mean square; $n=$ pairs of values of $(\mathrm{Y})$ and $(\mathrm{X}) ; t_{b}=$ compare the computed $t_{b}$ value to the tabular $t$ values with $(\mathrm{n}-2)$ degrees of freedom; $b$ is judged to be significantly different 
from zero if absolute value of the computed $t_{b}$ value is greater than the tabular $t$ value at the prescribed level of significance.

Simple linear correlation analysis was calculated, and the correlation coefficients were tested for significance [41]. The simple linear correlation coefficient ( $r$ ) was calculated as follows:

$$
r=\frac{\sum x y}{\sqrt{\left(\sum x^{2}\right)\left(\sum y^{2}\right)}}
$$

where $r$ is declared significant at the level of significant if the absolute value of the computed $r$ value is greater than the corresponding tubular $r$ value at the level of significance with (n-2) degrees of freedom.

\section{Results and Discussion}

\subsection{Analysis of Variance}

Mean squares for all parameters from combined analysis of variance across four environments are presented in Tables 3 and 4. Environment, cycle and environment by cycle interaction were highly significant $(p \leq 0.01)$ for all traits (Table 3). Population and environment by population interactions were highly significant for most traits except for cob mass. The interactions between population and cycle were also significant for most traits except for cob mass and days to anthesis. The interactions among environment, population and cycle were highly significant for most observed traits except for cob mass, days to anthesis and ear height. All sources of variation (SOV) were highly significant for TAC, TPC, DPPH and TEAC in corn husks and cobs (Table 4).

Table 3. Mean squares for grain yield, agronomic traits and total anthocyanin yield (TAY) of five populations and five cycles evaluated across four environments.

\begin{tabular}{|c|c|c|c|c|c|c|c|c|c|}
\hline \multirow{2}{*}{ SOV } & \multirow{2}{*}{$d f$} & \multirow{2}{*}{$\begin{array}{l}\text { Grain } \\
\text { Yield }\end{array}$} & \multirow{2}{*}{ Husk Mass } & \multirow{2}{*}{ Cob Mass } & \multirow{2}{*}{$\begin{array}{l}\text { Anthesis } \\
\text { Day }\end{array}$} & \multirow{2}{*}{$\begin{array}{l}\text { Plant } \\
\text { Height }\end{array}$} & \multirow{2}{*}{ Ear Height } & \multicolumn{2}{|c|}{ TAY } \\
\hline & & & & & & & & Husk & Cob \\
\hline Environment (E) & 3 & $\begin{array}{c}4807,326^{* *} \\
(9.9)\end{array}$ & $\begin{array}{c}1,304,911^{* * *} \\
(63.8)\end{array}$ & $\begin{array}{c}767,987^{* *} \\
(56.7)\end{array}$ & $\begin{array}{c}417.6^{* *} \\
(66.7)\end{array}$ & $\begin{array}{c}17,188^{* *} \\
(60.6)\end{array}$ & $\begin{array}{c}10,297^{* * *} \\
(58.4)\end{array}$ & $\begin{array}{c}261.9 * * \\
(5.0)\end{array}$ & $\begin{array}{c}235.4^{* *} \\
(17.0)\end{array}$ \\
\hline Error (a) & 8 & $\begin{array}{c}187,251 \\
(1.0)\end{array}$ & $\begin{array}{l}5007 \\
(0.7)\end{array}$ & $\begin{array}{l}6332 \\
(1.2)\end{array}$ & $\begin{array}{c}0.4 \\
(0.2)\end{array}$ & $\begin{array}{l}423 \\
(4.0)\end{array}$ & $\begin{array}{c}124 \\
(1.9)\end{array}$ & $\begin{array}{c}0.5 \\
(0.0)\end{array}$ & $\begin{array}{c}0.3 \\
(0.1)\end{array}$ \\
\hline Population (P) & 4 & $\begin{array}{c}4,442,353 \text { ** } \\
(12.2)\end{array}$ & $\begin{array}{c}27,888^{* *} \\
(1.8)\end{array}$ & $\begin{array}{c}4032 \mathrm{~ns} \\
(0.4)\end{array}$ & $\begin{array}{l}4.4^{* *} \\
(0.9)\end{array}$ & $\begin{array}{c}633^{* * *} \\
(3.0)\end{array}$ & $\begin{array}{c}755^{* *} \\
(5.7)\end{array}$ & $\begin{array}{c}10.5^{* *} \\
(0.0)\end{array}$ & $\begin{array}{c}10.1^{* *} \\
(1.0)\end{array}$ \\
\hline $\mathrm{E} \times \mathrm{P}$ & 12 & $\begin{array}{c}1,227,452 \text { ** } \\
(10.1)\end{array}$ & $\begin{array}{c}32,021 \text { ** } \\
(6.3)\end{array}$ & $\begin{array}{c}7265 \mathrm{~ns} \\
(2.1)\end{array}$ & $\begin{array}{l}3.4^{* *} \\
(2.2)\end{array}$ & $\begin{array}{l}134^{*} \\
(1.9)\end{array}$ & $\begin{array}{l}98^{* * *} \\
(2.2)\end{array}$ & $\begin{array}{l}3.0^{* *} \\
(0.0)\end{array}$ & $\begin{array}{l}3.2 * * \\
(1.0)\end{array}$ \\
\hline Error (b) & 32 & $\begin{array}{c}315,902 \\
(6.9)\end{array}$ & $\begin{array}{l}3573 \\
(1.9)\end{array}$ & $\begin{array}{l}6297 \\
(5.0)\end{array}$ & $\begin{array}{c}0.7 \\
(1.2)\end{array}$ & $\begin{array}{c}54 \\
(2.0)\end{array}$ & $\begin{array}{c}34 \\
(2.1)\end{array}$ & $\begin{array}{c}0.6 \\
(0.1)\end{array}$ & $\begin{array}{c}0.3 \\
(0.2)\end{array}$ \\
\hline Cycle (C) & 4 & $\begin{array}{c}2,407,467 \text { ** } \\
(6.6)\end{array}$ & $\begin{array}{c}34,362 * * \\
(2.2)\end{array}$ & $\begin{array}{c}23,619 * * \\
(2.3)\end{array}$ & $\begin{array}{l}94.5^{* *} \\
(20.1)\end{array}$ & $\begin{array}{l}761^{* *} \\
(3.6)\end{array}$ & $\begin{array}{c}1247^{* *} \\
(9.4)\end{array}$ & $\begin{array}{c}3114.9^{* *} \\
(88.0)\end{array}$ & $\begin{array}{c}580.4^{* *} \\
(57.0)\end{array}$ \\
\hline $\mathrm{E} \times \mathrm{C}$ & 12 & $\begin{array}{c}755,443 \text { ** } \\
(6.2)\end{array}$ & $\begin{array}{c}12,801 \text { ** } \\
(2.5)\end{array}$ & $\begin{array}{c}16,269 * * \\
(4.8)\end{array}$ & $\begin{array}{l}6.1 * * \\
(3.9)\end{array}$ & $\begin{array}{c}301 \text { ** } \\
(4.2)\end{array}$ & $\begin{array}{c}203 \text { ** } \\
(4.6)\end{array}$ & $\begin{array}{c}46.9^{* *} \\
(4.0)\end{array}$ & $\begin{array}{c}58.3^{* * *} \\
(17.0)\end{array}$ \\
\hline $\mathrm{P} \times \mathrm{C}$ & 16 & $\begin{array}{c}486,361 \text { * } \\
(5.3)\end{array}$ & $\begin{array}{c}10,016^{* *} \\
(2.6)\end{array}$ & $\begin{array}{c}\text { 5131ns } \\
(2.0)\end{array}$ & $\begin{array}{c}0.5 \mathrm{~ns} \\
(0.4)\end{array}$ & $\begin{array}{c}221^{* *} \\
(4.2)\end{array}$ & $\begin{array}{l}90 \text { ** } \\
(2.7)\end{array}$ & $\begin{array}{l}3.6^{* *} \\
(0.0)\end{array}$ & $\begin{array}{l}4.7 * * \\
(1.0)\end{array}$ \\
\hline $\mathrm{E} \times \mathrm{P} \times \mathrm{C}$ & 48 & $\begin{array}{c}402,421 \text { * } \\
(13.2)\end{array}$ & $\begin{array}{c}7887^{* *} \\
(6.2)\end{array}$ & $\begin{array}{c}4764 \mathrm{~ns} \\
(5.6)\end{array}$ & $\begin{array}{c}0.4 \mathrm{~ns} \\
(0.9)\end{array}$ & $\begin{array}{l}66^{* *} \\
(3.7)\end{array}$ & $\begin{array}{l}30 \mathrm{~ns} \\
(2.7)\end{array}$ & $\begin{array}{c}2.0^{* *} \\
(0.0)\end{array}$ & $\begin{array}{l}1.9 * * \\
(2.0)\end{array}$ \\
\hline Pooled error (c) & 160 & $\begin{array}{c}261,380 \\
(28.6)\end{array}$ & $\begin{array}{c}4623 \\
(12.1)\end{array}$ & $\begin{array}{c}5028 \\
(19.8)\end{array}$ & $\begin{array}{c}0.4 \\
(3.4)\end{array}$ & $\begin{array}{c}69 \\
(12.9)\end{array}$ & $\begin{array}{c}34 \\
(10.3)\end{array}$ & $\begin{array}{c}0.6 \\
(0.7)\end{array}$ & $\begin{array}{c}0.3 \\
(1.0)\end{array}$ \\
\hline $\mathrm{CV}(\mathrm{a})^{1}$ & & 6.2 & 8.3 & 8.7 & 1.2 & 10.9 & 11.7 & 8.6 & 14.3 \\
\hline $\mathrm{CV}(\mathrm{b})^{1}$ & & 8.1 & 7.0 & 8.7 & 1.5 & 3.9 & 6.1 & 9.7 & 12.3 \\
\hline$C V(c)^{1}$ & & 7.3 & 8.0 & 7.8 & 1.2 & 4.4 & 6.1 & 9.4 & 12.3 \\
\hline
\end{tabular}

ns, ${ }^{*}, * *$ not significant and significant at 0.05 and 0.01 probability levels, respectively; the number within the parentheses is relative percentage of sum squares to total sum of squares; ${ }^{1}$ Coefficient of variation (CV) is a measure of (a) environment, (b) population and population by environment interaction, cycle and cycle by environment interaction, cycle by population interaction and (c) cycle by population by environment interaction.

Environment effects accounted for a large portion (56.7\% to $66.7 \%)$ of the total variations for husk mass, cob mass, days to anthesis, plant height and ear height (Table 3). Populations responded differently to individual environments for husk mass, cob mass, days to anthesis, plant height and ear height (Tables A1, A1 and A3). However, the dry season was higher than the rainy season at both Khon Kaen location and Uthai Thani location. Growing season was the most important environmental 
factors affecting performance of this corn populations. The large effects of the environment have also been reported in quality protein maize for yield [43] and flowering traits [44]. The effect of environment also affected anthocyanin content, antioxidant activity in corn cobs [45], total anthocyanin content and total phenolic content in husk, cob, silk and tassel in purple waxy corn [46]. Days to tasseling and days to silking in purple waxy corn were also greatly affected by environment [32]. In this study, as the crop was irrigated, soil moisture may not cause large differences. However, the large differences would be possible due to the growing season and elevation of the experimental sites. Differences in average daily temperature at the sites for example are likely associated with the differences in accumulations of corn heat units (CHU) [47]. CHUs are known to control the developmental program of corn and affect such traits as flowering date [48]. The results suggested that environmental factors were important for the expression of these traits and different genotypes responded differently to the different environmental factors. In addition, environment effects accounted for small portions of the total variations for TAY in husk and cob, TAC, TPC, DPPH and TEAC (Tables 3 and 4). The populations responded in a similar pattern in individual environments (Tables A4-A8).

Table 4. Mean squares for total anthocyanin content (TAC), total phenolic content (TPC) and antioxidant activity determined by the DPPH and the TEAC methods of five populations and five cycles evaluated across four environments.

\begin{tabular}{|c|c|c|c|c|c|c|c|c|c|}
\hline \multirow{2}{*}{ SOV } & \multirow{2}{*}{$d f$} & \multicolumn{4}{|c|}{ Husk } & \multicolumn{4}{|c|}{ Cob } \\
\hline & & TAC & TPC & DPPH & TEAC & TAC & TPC & DPPH & TEAC \\
\hline Environment (E) & 3 & $\begin{array}{c}224,274 \text { ** } \\
(0.4)\end{array}$ & $\begin{array}{c}440,534 \text { ** } \\
(0.7)\end{array}$ & $\begin{array}{c}174,023 \text { ** } \\
(10.5)\end{array}$ & $\begin{array}{c}2,262,768^{* *} \\
(4.7)\end{array}$ & $\begin{array}{c}1,483,875 \text { ** } \\
(12.4)\end{array}$ & $\begin{array}{c}179,389 \text { ** } \\
(0.8)\end{array}$ & $\begin{array}{c}1292 * * \\
(0.3)\end{array}$ & $\begin{array}{c}2,517,996^{* *} \\
(10.6)\end{array}$ \\
\hline Error (a) & 8 & $\begin{array}{l}1257 \\
(0.0)\end{array}$ & $\begin{array}{l}2564 \\
(0.0)\end{array}$ & $\begin{array}{c}26 \\
(0.0)\end{array}$ & $\begin{array}{l}1094 \\
(0.0)\end{array}$ & $\begin{array}{l}720 \\
(0.0)\end{array}$ & $\begin{array}{l}792 \\
(0.0)\end{array}$ & $\begin{array}{c}28 \\
(0.0)\end{array}$ & $\begin{array}{l}2577 \\
(0.0)\end{array}$ \\
\hline Population (P) & 4 & $\begin{array}{c}55,357 * * \\
(0.1)\end{array}$ & $\begin{array}{c}133,723 \text { ** } \\
(0.3)\end{array}$ & $\begin{array}{c}1512 * * \\
(0.1)\end{array}$ & $\begin{array}{c}165,909 \text { ** } \\
(0.5)\end{array}$ & $\begin{array}{c}103,969^{* * *} \\
(1.2)\end{array}$ & $\begin{array}{c}211,480 * * \\
(1.3)\end{array}$ & $\begin{array}{l}417^{* *} \\
(0.1)\end{array}$ & $\begin{array}{c}91,273^{* *} \\
(0.5)\end{array}$ \\
\hline ExP & 12 & $\begin{array}{c}29,413 \text { ** } \\
(0.2)\end{array}$ & $\begin{array}{c}34,349 * * \\
(0.2)\end{array}$ & $\begin{array}{c}581 * * \\
(0.1)\end{array}$ & $\begin{array}{c}18,513 * * \\
(0.2)\end{array}$ & $\begin{array}{c}35,550 * * \\
(1.2)\end{array}$ & $\begin{array}{c}60,721 \text { ** } \\
(1.1)\end{array}$ & $\begin{array}{c}600 * * \\
(0.6)\end{array}$ & $\begin{array}{c}23,256^{* *} \\
(0.4)\end{array}$ \\
\hline Error (b) & 32 & $\begin{array}{c}662 \\
(0.0)\end{array}$ & $\begin{array}{l}1154 \\
(0.0)\end{array}$ & $\begin{array}{c}15 \\
(0.0)\end{array}$ & $\begin{array}{c}944 \\
(0.0)\end{array}$ & $\begin{array}{c}234 \\
(0.0)\end{array}$ & $\begin{array}{l}1309 \\
(0.1)\end{array}$ & $\begin{array}{c}31 \\
(0.1)\end{array}$ & $\begin{array}{l}1141 \\
(0.1)\end{array}$ \\
\hline Cycle (C) & 4 & $\begin{array}{c}39,180,000 * * \\
(98.1)\end{array}$ & $\begin{array}{c}46,300,000 \text { ** } \\
(96.6)\end{array}$ & $\begin{array}{c}1,048,430 \text { ** } \\
(84.7)\end{array}$ & $\begin{array}{l}32,890,000 \text { ** } \\
(91.6)\end{array}$ & $\begin{array}{c}5,970,024 \text { ** } \\
(66.3)\end{array}$ & $\begin{array}{c}13,570,000 * * \\
(82.2)\end{array}$ & $\begin{array}{c}274,538 \text { ** } \\
(93.5)\end{array}$ & $\begin{array}{c}14,200,000 \text { ** } \\
(80.0)\end{array}$ \\
\hline ExC & 12 & $\begin{array}{c}52,823 * * \\
(0.4)\end{array}$ & $\begin{array}{c}122,870 * * \\
(0.8)\end{array}$ & $\begin{array}{c}14,594^{* * *} \\
(3.5)\end{array}$ & $\begin{array}{c}2,170,888^{* *} \\
(1.8)\end{array}$ & $\begin{array}{c}425,840 \text { ** } \\
(14.2)\end{array}$ & $\begin{array}{c}461,858^{* *} \\
(8.4)\end{array}$ & $\begin{array}{c}2662 * * \\
(2.7)\end{array}$ & $\begin{array}{c}384,372 \text { ** } \\
(6.5)\end{array}$ \\
\hline $\mathrm{PxC}$ & 16 & $\begin{array}{c}24,714 \text { ** } \\
(0.2)\end{array}$ & $\begin{array}{c}53,517 \text { ** } \\
(0.4)\end{array}$ & $\begin{array}{c}728^{* *} \\
(0.2)\end{array}$ & $\begin{array}{c}30,065 \text { ** } \\
(0.3)\end{array}$ & $\begin{array}{c}47,058^{* *} \\
(2.1)\end{array}$ & $\begin{array}{c}85,369 * * \\
(2.1)\end{array}$ & $\begin{array}{c}238^{* *} \\
(0.3)\end{array}$ & $\begin{array}{c}26,893 \text { ** } \\
(0.6)\end{array}$ \\
\hline ExPxC & 48 & $\begin{array}{c}12,199 * * \\
(0.4)\end{array}$ & $\begin{array}{c}35,064^{* *} \\
(0.9)\end{array}$ & $\begin{array}{c}715^{* *} \\
(0.7)\end{array}$ & $\begin{array}{c}21,193 \text { ** } \\
(0.7)\end{array}$ & $\begin{array}{c}19,106 * * \\
(2.5)\end{array}$ & $\begin{array}{c}53,219 * * \\
(3.9)\end{array}$ & $\begin{array}{l}487 * * \\
(2.0)\end{array}$ & $\begin{array}{c}14,603 \text { ** } \\
(1.0)\end{array}$ \\
\hline Pooled error (c) & 160 & $\begin{array}{l}810 \\
(0.1) \\
\end{array}$ & $\begin{array}{l}1205 \\
(0.1) \\
\end{array}$ & $\begin{array}{c}20 \\
(0.1)\end{array}$ & $\begin{array}{l}648 \\
(0.1) \\
\end{array}$ & $\begin{array}{l}345 \\
(0.2) \\
\end{array}$ & $\begin{array}{l}1004 \\
(0.2) \\
\end{array}$ & $\begin{array}{c}23 \\
(0.3) \\
\end{array}$ & $\begin{array}{l}1029 \\
(0.2) \\
\end{array}$ \\
\hline $\mathrm{CV}(\mathrm{a})^{1}$ & & 3.8 & 4.5 & 2.9 & 3.8 & 6.3 & 3.5 & 4.8 & 7.1 \\
\hline $\mathrm{CV}(\mathrm{b})^{1}$ & & 2.7 & 3.0 & 2.1 & 3.5 & 3.6 & 4.5 & 5.0 & 4.7 \\
\hline $\mathrm{CV}(\mathrm{c})^{1}$ & & 3.0 & 3.1 & 2.5 & 2.9 & 4.3 & 3.9 & 4.4 & 4.5 \\
\hline
\end{tabular}

** significant at 0.01 probability levels; the number within the parentheses is relative percentage of sum squares to total sum of squares; TAC — mg CGE/g 100 DW; TPC — mg GAE/100 g DW; TEAC — mmol TE/100 g DW; DPPHmmol TE/100 g DW; ${ }^{1}$ Coefficient of variation (CV) is a measure of (a) environment, (b) population and population by environment interaction, cycle and cycle by environment interaction, cycle by population interaction and (c) cycle by population by environment interaction.

Cycle contributed to a large portion $(66.3 \%$ to $98.1 \%)$ of the total variations for TAC, TPC, DPPH and TEAC in corn husk and cob (Table 4). The results demonstrated the effectiveness of improving anthocyanin levels and antioxidant activity through modified mass selection. Genotype effects were predominant in anthocyanin concentrations in both kernel [49] and cob [45] of purple waxy corn and other phytochemicals in field corn such as total phenolics [50] and various carotenoids [51]. The significant interaction between population and cycle with a small contribution indicated the differential responses to selection among the populations.

\subsection{Response to Selection}

A negative linear response to selection was found for (number of) days to anthesis ranging from -0.66 days per cycle to -0.85 days per cycle (Table 5 ). Modified mass selection effectively improved early flowering among populations by three or four days. The results supported previous findings on 
Spanish synthetic maize populations [28] and purple waxy corn populations [32]. The genetic gain for reduction in days to anthesis increased in association with cycles of selection. Responses to selection among populations were not significant for grain yield, husk mass, cob mass, plant height and ear height (Table 5). A strong emphasis was placed on selecting plants with pigmented husks during population improvement. Yield was selected indirectly through selection for large ears. The improved populations showed appreciable gains for agronomic performance without significant yield loss. The response for yield in these populations would be possible due to unintentional selection [52]. Visual selection of desirable individuals at each stage may increase the selection efficiency. Heritability estimates $\left(h_{b}^{2}\right)$ for GY ranged from 0 to 0.98 (Table 5). Heritability estimates were high in some environments and low in some environments. The results indicated that environmental effect was important for the variation in grain yield. Heritability estimates $\left(h_{b}^{2}\right)$ for TAY in husk and cob ranged from 0.97 to 0.99 (Table 5). High heritability estimates indicated that the trait was stable across environments and selection in any environment was effective.

Table 5. Means for grain yield, agronomic traits and total anthocyanin yield (TAY) of (A-E) five populations and (C0-C4) five cycles evaluated across four environments.

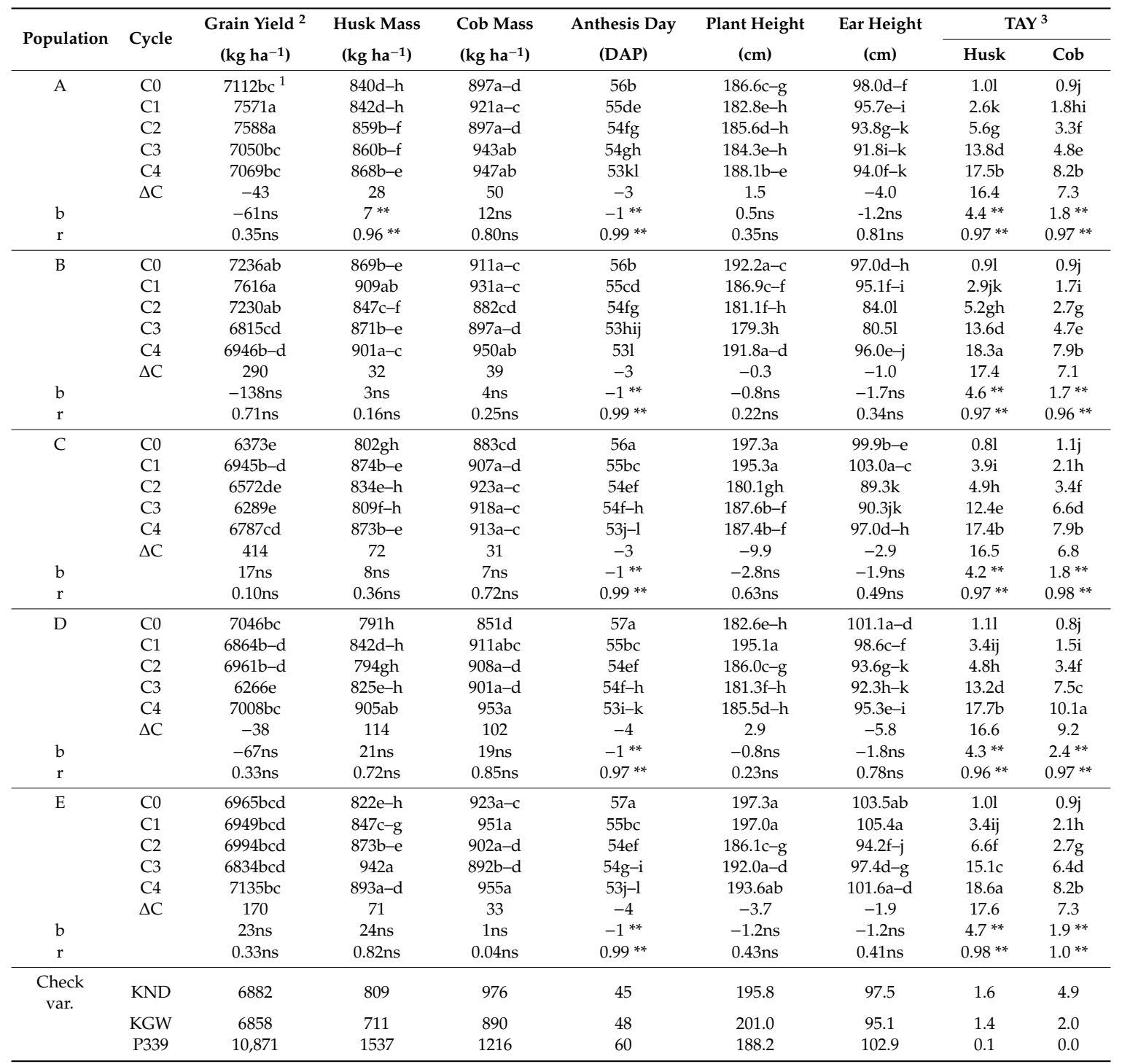

ns and ${ }^{* *}$ not significant and significant at 0.01 probability levels; ${ }^{1}$ means in a column followed by the same letter are not significantly different at 0.05 probability levels; $\mathrm{b}=$ response to selection; TAY - $\mathrm{kg}$ CGE/DW ha ${ }^{-1} ; \mathrm{r}-\mathrm{correlation}$ coefficient; DAP — days after planting; ${ }^{2}$ : broad sense heritability $\left(h_{b}^{2}\right)$ for grain yield, ranged from 0 to $0.98,{ }^{3}$ : broad sense heritability $\left(h_{b}^{2}\right)$ for TAY in husk and cob, ranged from 0.97 to $0.99 ; \Delta C=$ selection differential mean $C 0$ and $C 4$. 
In corn husk, significant and positive linear responses to selection were observed for TAY (Table 5), TAC, TPC, DPPH and TEAC (Table 6). Among the five populations, population E $(\mathrm{NS} 3 \times \mathrm{PF}$ ) showed the most impressive selection progress for phytochemical attributes such as TAY

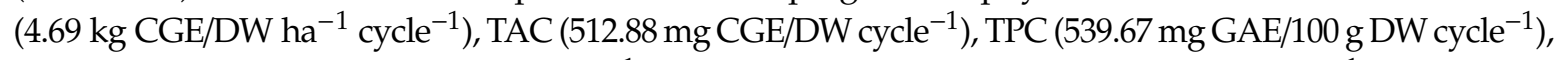
DPPH (83.10 mmol TE/100 g DW cycle ${ }^{-1}$ ) and TEAC (493.37 mmol TE/100 g DW cycle $\left.{ }^{-1}\right)$.

Table 6. Means for total anthocyanin content (TAC), total phenolic content (TPC) and antioxidant activity determined by the DPPH and the TEAC methods of (A-E) five populations and (C0-C4) five cycles evaluated across four environments.

\begin{tabular}{|c|c|c|c|c|c|c|c|c|c|}
\hline \multirow{2}{*}{ Population } & \multirow{2}{*}{ Cycle } & \multicolumn{4}{|c|}{ Husk } & \multicolumn{4}{|c|}{$\mathrm{Cob}$} \\
\hline & & TAC & TPC & DPPH & TEAC & TAC & TPC & DPPH & TEAC \\
\hline \multirow[t]{6}{*}{$\mathrm{A}$} & $\mathrm{CO}$ & 123.6 no $^{1}$ & $179.0 \mathrm{p}$ & 37.7op & $171.0 \mathrm{p}$ & $96.6 n$ & $256.0 \mathrm{q}$ & $36.6 \mathrm{kl}$ & $141.5 p$ \\
\hline & $\mathrm{C} 1$ & $308.4 \mathrm{~m}$ & $484.3 \mathrm{~m}$ & $94.8 \mathrm{~m}$ & $334.4 n$ & $196.6 \mathrm{k}$ & $435.1 n$ & $52.7 \mathrm{j}$ & $357.8 \mathrm{k}$ \\
\hline & $\mathrm{C} 2$ & $643.6 \mathrm{i}$ & $896.7 \mathrm{~h}$ & $129.6 \mathrm{~h}$ & $554.7 \mathrm{k}$ & $355.1 \mathrm{~g}$ & $714.4 \mathrm{i}$ & $91.7 \mathrm{~g}$ & $583.7 \mathrm{~h}$ \\
\hline & $\mathrm{C} 3$ & $1601.5 \mathrm{e}$ & $1812.1 \mathrm{~d}$ & $307.1 \mathrm{e}$ & $1266.8 \mathrm{i}$ & $504.2 \mathrm{f}$ & $1002.5 \mathrm{~h}$ & $157.2 \mathrm{~d}$ & $1009.5 \mathrm{e}$ \\
\hline & $\mathrm{C} 4$ & $1984.8 \mathrm{c}$ & $2337.3 b$ & $344.7 \mathrm{c}$ & $1893.1 \mathrm{c}$ & $826.8 b$ & $1594.3 b$ & $191.1 b$ & $1320.2 \mathrm{c}$ \\
\hline & $\Delta C$ & 1861.2 & 2158.3 & 307.0 & 1722.1 & 730.2 & 1338.3 & 154.6 & 1178.7 \\
\hline $\mathrm{b}$ & & $501.6^{* *}$ & $564.4^{* *}$ & $82.6^{* *}$ & $437.7 * *$ & $176.8^{* *}$ & $324.4^{* *}$ & $41.4^{* *}$ & $300.9^{* *}$ \\
\hline $\mathrm{r}$ & & $0.97^{* *}$ & $0.98^{* *}$ & $0.97^{* *}$ & $0.96^{* *}$ & $1.00 * *$ & $0.97^{* *}$ & $0.98^{* *}$ & $0.99 * *$ \\
\hline \multirow[t]{6}{*}{$\mathrm{B}$} & $\mathrm{CO}$ & $109.4 \mathrm{o}$ & 210.10 & $40.2 \mathrm{o}$ & $166.9 p$ & $93.1 \mathrm{n}$ & $262.3 q$ & 33.81 & 189.10 \\
\hline & $\mathrm{C} 1$ & $321.9 \mathrm{~m}$ & $471.3 \mathrm{~m}$ & $98.6 \mathrm{kl}$ & $303.0 \mathrm{o}$ & 180.61 & $504.5 \mathrm{~m}$ & $53.3 \mathrm{j}$ & $357.8 \mathrm{k}$ \\
\hline & $\mathrm{C} 2$ & $601.4 \mathrm{j}$ & $647.7 \mathrm{j}$ & $116.4 \mathrm{j}$ & $555.8 \mathrm{k}$ & $312.1 \mathrm{~h}$ & 593.61 & $102.0 \mathrm{e}$ & $502.7 \mathrm{i}$ \\
\hline & $\mathrm{C} 3$ & $1546.4 \mathrm{f}$ & 1781.0ef & $284.4 \mathrm{~g}$ & $1273.2 \mathrm{i}$ & $515.0 \mathrm{f}$ & $987.1 \mathrm{~h}$ & $157.3 d$ & $976.7 \mathrm{f}$ \\
\hline & $\mathrm{C} 4$ & $2016.5 b$ & $2248.2 \mathrm{c}$ & $325.0 \mathrm{~d}$ & $1826.4 \mathrm{e}$ & $806.1 \mathrm{c}$ & $1264.8 \mathrm{~d}$ & $203.3 a$ & $1313.5 \mathrm{c}$ \\
\hline & $\Delta C$ & 1907.1 & 2038.1 & 284.8 & 1659.5 & 713.0 & 1002.5 & 169.5 & 1124.4 \\
\hline $\mathrm{b}$ & & $503.9^{* *}$ & 538.6 * & $75.5^{* *}$ & $428.9 * *$ & $176.0^{* *}$ & $248.8^{* *}$ & $44.3^{* *}$ & $286.8^{* *}$ \\
\hline $\mathrm{r}$ & & $0.97^{* *}$ & $0.96^{* *}$ & $0.96^{* *}$ & $0.96^{* *}$ & $0.97^{* *}$ & $0.98^{* *}$ & $0.99^{* *}$ & $0.98^{* *}$ \\
\hline \multirow[t]{6}{*}{$C$} & $\mathrm{CO}$ & $102.2 \mathrm{o}$ & 212.50 & $35.8 p$ & $172.3 p$ & $118.9 \mathrm{~m}$ & $315.7 p$ & $38.4 \mathrm{k}$ & $216.8 \mathrm{mn}$ \\
\hline & $\mathrm{C} 1$ & $441.6 \mathrm{k}$ & $675.6 \mathrm{j}$ & $99.0 \mathrm{k}$ & $384.0 \mathrm{~m}$ & $235.1 \mathrm{j}$ & 596.61 & 59.2hi & $444.8 \mathrm{j}$ \\
\hline & $\mathrm{C} 2$ & $583.5 \mathrm{j}$ & $750.3 \mathrm{i}$ & $123.6 \mathrm{i}$ & 518.91 & $356.5 \mathrm{~g}$ & $727.4 \mathrm{i}$ & $105.5 \mathrm{e}$ & $637.0 \mathrm{~g}$ \\
\hline & $\mathrm{C} 3$ & $1522.8 \mathrm{~g}$ & $1760.1 f$ & $281.2 \mathrm{~g}$ & $1306.3 \mathrm{~h}$ & $694.1 \mathrm{e}$ & $1127.4 \mathrm{f}$ & $165.2 \mathrm{c}$ & $1022.8 \mathrm{e}$ \\
\hline & $\mathrm{C} 4$ & $1972.0 \mathrm{c}$ & $2342.4 \mathrm{~b}$ & $351.5 \mathrm{~b}$ & $1854.6 \mathrm{~d}$ & $827.1 b$ & $1443.6 \mathrm{c}$ & $189.6 \mathrm{~b}$ & $1327.5 \mathrm{c}$ \\
\hline & $\Delta C$ & 1869.8 & 2129.9 & 315.6 & 1682.3 & 708.2 & 1127.9 & 151.2 & 1110.7 \\
\hline $\mathrm{b}$ & & $482.1^{* *}$ & $534.4^{* *}$ & $81.3^{* *}$ & 428.7 * & $187.5^{* *}$ & $278.7^{* *}$ & $40.9^{* *}$ & $279.9^{* *}$ \\
\hline $\mathrm{r}$ & & $0.97^{* *}$ & $0.97^{* *}$ & $0.97^{* *}$ & $0.96^{* *}$ & $0.98^{* *}$ & $0.99^{* *}$ & $0.99^{* *}$ & $0.99 * *$ \\
\hline \multirow[t]{6}{*}{$\mathrm{D}$} & $\mathrm{CO}$ & $144.8 n$ & $260.1 n$ & $40.5 \mathrm{o}$ & $167.1 p$ & $97.7 n$ & 358.10 & $39.8 \mathrm{k}$ & $238.4 \mathrm{~m}$ \\
\hline & $\mathrm{C} 1$ & 394.41 & 554.21 & $95.41 \mathrm{~m}$ & $338.0 \mathrm{n}$ & 169.21 & $499.7 \mathrm{~m}$ & $56.0 \mathrm{ij}$ & $378.0 \mathrm{k}$ \\
\hline & $\mathrm{C} 2$ & $584.4 j$ & $736.8 \mathrm{i}$ & $116.6 \mathrm{j}$ & 530.81 & $363.4 \mathrm{~g}$ & $635.6 \mathrm{k}$ & $97.5 \mathrm{f}$ & $589.7 \mathrm{~h}$ \\
\hline & $\mathrm{C} 3$ & $1588.4 \mathrm{e}$ & $1792.9 \mathrm{de}$ & $296.7 f$ & $1387.7 \mathrm{~g}$ & $782.5 \mathrm{~d}$ & $1177.9 \mathrm{e}$ & $166.1 \mathrm{c}$ & $1092.0 \mathrm{~d}$ \\
\hline & $\mathrm{C} 4$ & $1944.7 \mathrm{~d}$ & $2266.3 c$ & $344.5 \mathrm{~s}$ & $1957.5 b$ & $1018.2 \mathrm{a}$ & $1728.8 \mathrm{a}$ & $201.3 a$ & $1531.6 a$ \\
\hline & $\Delta \mathrm{C}$ & 1799.9 & 2006.2 & 304.0 & 1790.4 & 920.5 & 1370.7 & 161.5 & 1293.2 \\
\hline $\mathrm{b}$ & & $479.4^{* *}$ & $525.1^{* *}$ & $81.3^{* *}$ & 463.1 * & $245.4^{* *}$ & 342.0 * & $43.3^{* *}$ & $330.0^{* *}$ \\
\hline $\mathrm{r}$ & & $0.96^{* *}$ & $0.96^{* *}$ & $0.97^{* *}$ & $0.96^{* *}$ & $0.97^{* *}$ & $0.95^{*}$ & $0.98^{* *}$ & $0.97^{* *}$ \\
\hline \multirow[t]{6}{*}{$E$} & $\mathrm{CO}$ & $121.0 \mathrm{o}$ & $277.9 n$ & $48.1 \mathrm{n}$ & $172.3 p$ & $101.1 \mathrm{n}$ & $298.0 p$ & $36.7 \mathrm{kl}$ & 201.8 no \\
\hline & $\mathrm{C} 1$ & 406.61 & $590.1 \mathrm{k}$ & $93.7 \mathrm{~m}$ & $391.6 \mathrm{~m}$ & $224.7 j$ & $502.8 \mathrm{~m}$ & $60.7 \mathrm{~h}$ & 328.91 \\
\hline & $\mathrm{C} 2$ & $752.1 \mathrm{~h}$ & $972.7 \mathrm{~g}$ & $130.6 \mathrm{~h}$ & $648.2 \mathrm{j}$ & $297.2 \mathrm{i}$ & $670.3 \mathrm{j}$ & $105.8 \mathrm{e}$ & $582.6 \mathrm{~h}$ \\
\hline & $\mathrm{C} 3$ & $1600.0 \mathrm{e}$ & 1799.4de & $296.2 f$ & $1489.5 \mathrm{f}$ & $685.5 \mathrm{e}$ & $1045.2 \mathrm{~g}$ & $165.1 \mathrm{c}$ & $1086.2 d$ \\
\hline & $\mathrm{C} 4$ & $2088.7 \mathrm{a}$ & $2371.6 a$ & $362.3 a$ & $2090.2 a$ & $831.4 \mathrm{~b}$ & $1425.8 \mathrm{c}$ & $191.6 b$ & $1397.5 b$ \\
\hline & $\Delta C$ & 1967.7 & 2093.7 & 314.2 & 1917.9 & 730.3 & 1127.8 & 154.9 & 1195.7 \\
\hline$b$ & & $512.9 * *$ & $539.7 * *$ & $83.1^{* *}$ & $493.4 * *$ & $192.1^{* *}$ & $279.8^{* *}$ & $41.4^{* *}$ & $314.9^{* *}$ \\
\hline $\mathrm{r}$ & & $0.98^{* *}$ & $0.98 * *$ & $0.97^{* *}$ & $0.97 * *$ & $0.97^{* *}$ & $0.98^{* *}$ & $0.99^{* *}$ & $0.98^{* *}$ \\
\hline \multirow[t]{3}{*}{ Check var. } & KND & 192.8 & 335.9 & 50.1 & 229.1 & 494.4 & 987.6 & 130.9 & 981.0 \\
\hline & KGW & 177.8 & 313.6 & 46.4 & 205.7 & 208.7 & 440.8 & 86.8 & 564.5 \\
\hline & P339 & 6.0 & 34.9 & 14.8 & 40.9 & 3.6 & 87.9 & 13.0 & 99.1 \\
\hline
\end{tabular}

$\mathrm{ns},{ }^{*}$ and ${ }^{* *}$ non-significant and significant at 0.05 and 0.01 probability levels, respectively; ${ }^{1}$ means in a column followed by the same letter are not significantly different at 0.05 probability levels; $b-$ response to selection; TAC - mg CGE/g 100 DW; TPC-mg GAE/100 g DW; TEAC-mmol TE/100 g DW; DPPH-mmol TE/100 g DW; $\mathrm{r}$-correlation coefficient; $\Delta \mathrm{C}$-selection differential mean $\mathrm{C} 0$ and $\mathrm{C} 4$.

Similar favorable responses were also found in corn cob. The responses to selection were positive and significant for TAY, TAC, TPC, DPPH and TEAC. Among the five populations, population D (NSX x PF4) had the best responses for TAY (2.44 kg CGE/DW ha ${ }^{-1}$ cycle $\left.^{-1}\right)$, TAC (245.43 mg CGE/DW cycle $\left.{ }^{-1}\right)$, TPC (341.96 mg GAE/100 g DW cycle $\left.{ }^{-1}\right)$, DPPH (43.31 mmol TE/100 g DW cycle ${ }^{-1}$ ) and TEAC (330.04 mmol TE/100 g DW cycle ${ }^{-1}$ ). 
The authors were not be able to determine whether the changes observed in the populations are due to the responses to selection or genetic drift. Comparison of the changes in the selected traits and unselected traits may reveal the likelihood of genetic drift [53]. In this study, days to anthesis, purple husk and purple cob were selected intentionally, and the traits changed in the course of the experiment. However, husk mass, cob mass, plant height and ear height were not selected and they were not affected by selection. These observations suggested that the observed changes in the selected traits were most likely due to selection.

The responses to modified mass selection for purple cob and purple husk in this study agreed well with the previous findings on selection of corn for pigmented corn cob [16] and pigmented corn kernel [54]. The authors pointed out that modified mass selection for color cob and color husk could increase anthocyanin content in just one cycle of selection without subsequent cycles. In our study, both genetic gains and mean values of phytochemical traits consistently increased as the populations were advanced in the subsequent selection cycles. Two factors, namely allele fixation by selection and genetic correlation with the targeted traits [52] may be responsible for the responses to selection for these traits.

Anthocyanin concentration in corn is heritable and regulated by multiple dominant genes $[55,56]$, including the P1 dominant allele that controls purple coloration in the corn cob and husk $[11,57]$. Allele frequency in the base population may be low [21], allele frequency may increase in response to selection for the plants with colored husks. High heritability estimates increased selection efficiency and resulted in the increases in the frequency of pigmented plants in each population and the mean value of the population. It is also possible that the level of pigmentation in individual plants increased as a result of selection. Modified mass selection by visual selection of colored plants is effective in increasing the number of colored plants and color intensity in the improved populations. In addition, the genetic correlation between visually scored color and phytochemical content could be the cause of the increased anthocyanin concentration in the improved populations. Purple color is strongly related to anthocyanin concentration and antioxidant activities in purple waxy corn [49].

Our results demonstrated the efficacy of modified mass selection to increase anthocyanin concentration in the improved populations after four cycles of selection (Figure 2). The C4 populations had higher anthocyanin concentrations than all check varieties. This study suggested that breeders can apply visual selection for dark purple husk and cob to boost the anthocyanin levels and antioxidant activity. Others studies, visual selection was also effective for increasing carotenoid content [1] and anthocyanin content in kernel [54]. The populations will be further improved for uniformity of colored plants and resistance to diseases and pests, and evaluation of stability for yield and phytochemicals will be carried out prior to use of these improved populations.

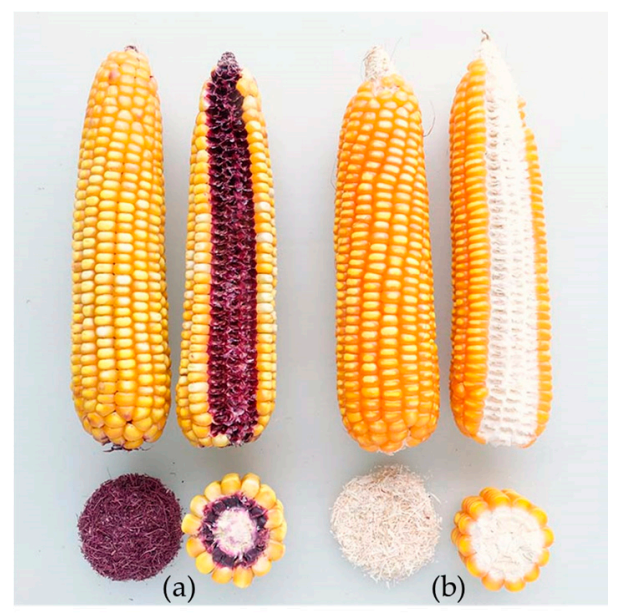

Figure 2. Comparison of purple husk and cob of (a) purple field corn and (b) white husk and cob of normal field corn. 


\subsection{Correlation}

Most correlation coefficients between total anthocyanin yield (TAY) in husk and cob and agronomic parameters including grain yield, husk mass, cob mass, days to anthesis, plant height and ear height were negative and low or not significant, ranging from -0.03 to -0.44 (Table 7). For husk mass and cob mass, the correlations were low, ranging from -0.03 to -0.12 . For grain yield, days to anthesis, plant height and ear height, the correlations were higher, ranging from -0.18 to -0.44 . The results may indicate that increase in TAY was somewhat detrimental to grain yield and other agronomic parameters, especially for days to anthesis. In corn, early maturity is preferable if it does not cause significant yield reduction [32].

Table 7. Pearson correlation coefficients between grain yield, agronomic traits, total anthocyanin content (TAC), total phenolic content (TPC) and antioxidant activity determined by the DPPH and the TEAC methods and total anthocyanin yield (TAY).

\begin{tabular}{ccc}
\hline Parameter & \multicolumn{2}{c}{ Total Anthocyanin Yield (TAY) } \\
\cline { 2 - 3 } & Husk & Cob \\
\hline Grain yield & $-0.28 \mathrm{~ns}$ & $-0.35 \mathrm{~ns}$ \\
Husk Mass & $-0.03 \mathrm{~ns}$ & $-0.12 \mathrm{~ns}$ \\
Cob Mass & $-0.04 \mathrm{~ns}$ & $-0.03 \mathrm{~ns}$ \\
Days to anthesis & $-0.24 \mathrm{~ns}$ & $-0.44^{*}$ \\
Plant height & $-0.24 \mathrm{~ns}$ & $-0.18 \mathrm{~ns}$ \\
Ear height & $-0.31 \mathrm{~ns}$ & $-0.27 \mathrm{~ns}$ \\
\hline Husk & & \\
\hline TAC & $1.00^{* *}$ & $0.94^{* *}$ \\
TPC & $1.00^{* *}$ & $0.94^{* *}$ \\
DPPH & $0.99^{* *}$ & $0.93^{* *}$ \\
TEAC & $0.99^{* *}$ & $0.95^{* *}$ \\
\hline Cob & & $1.00^{* *}$ \\
TAC & $0.94^{* *}$ & $0.99^{* *}$ \\
TPC & $0.93^{* *}$ & $0.97^{* *}$ \\
DPPH & $0.94^{* *}$ & $0.98^{* *}$ \\
TEAC & $0.93^{* *}$ &
\end{tabular}

Days to maturity is positively and significantly correlated with grain yield in many cereal crops such as maize [58], rice [59], sorghum [60] and pearl millet [61]. The low grain yield in early mature genotypes would be because the crops need more time to accumulate biomass and then the accumulated biomass is partitioned into economic yield. However, early mature genotypes can have higher yield than late mature genotypes in some cases. In maize, early mature hybrids with higher seedling strength had higher grain yield than late mature genotypes with poor seed vigor [62], and the genotypes with early maturity and resistance to late season drought had higher grain yield than late maturing genotypes [63].

The negative correlations between TAY and agronomic parameters would be possibly caused by the effect of environments. The stress environments favor the accumulation of anthocyanins of purple corn cob [37]. In maize, low temperature increases anthocyanins in kernel [64]. Similarly, abiotic stresses and nutrient deficiency also increase anthocyanins in corn kernel [65]. In contrast, optimum environmental factors such as plant population density [66], nutrients [67] and soil moisture [68] promote growth and yield of the crop. Independent segregation of anthocyanins and agronomic traits is preferable for selection of corn genotypes with high anthocyanins and high grain yield. However, there may be genetic relationships between these traits.

The TAC, TPC, DPPH, and TEAC in husk and cob were closely correlated with TAY in husk and $\operatorname{cob}\left(r=0.93^{* *}\right.$ to $\left.1.00^{* *}\right)$. The correlation coefficients between TAY and antioxidant activity (DPPH and 
TEAC) in husk $\left(0.99^{* *}\right.$ and $\left.0.99^{* *}\right)$ were not different from those in cob $\left(0.97^{* *}\right.$ and $\left.0.98^{* *}\right)$. The results indicated that TAC and TPC in husk and cob contributed to antioxidant and both husk and cob are promising as raw materials for anthocyanin extraction. Previous studies reported a strong association between kernel color and phytochemicals in corn. Purple color of corn was positively and significantly related to anthocyanins and antioxidant activities [25,49], and visually scored orange kernel color was associated with carotenoids $[69,70]$.

Anthocyanins are a naturally occurring type of flavonoid with antioxidant effects in many foods [71], and phenolic compounds are also found in plant tissues including fruits and vegetables [72]. Diversification of food consumption in our diet can therefore reduce the risk of noncommunicable diseases [73]. Corn can be consumed as both vegetable and cereal, and its byproducts can be used for phytochemical extraction in food industry.

Thus, visual screening for dark purple coloration in corn husk and cob could be applied as one of indirect selection criteria in modified mass selection to gain corn genotypes with high anthocyanins and antioxidant activities. The method can be applied in the early cycles of population improvement when the variation of colored plants is still high.

\section{Conclusions}

Cycle of selection explained a large portion of the total variance for TAC, TPC, DPPH and TEAC in corn husk and cob. All tested populations showed good progress for days to anthesis, TAY, TAC, TPC, DPPH and TEAC over four cycles of selection. Agronomic traits and anthocyanins could be independently used as complementary criteria of selection because these traits were poorly correlated. Modified mass selection was a successful method for development of the improved field corn populations with increased anthocyanin concentration, antioxidant activity and early flowering without losing significant yield. Two improved populations, D (NSX x PF4) and E (NS3 x PF5), had the highest selection gains per cycle for anthocyanin concentration in the corn cob and husk, respectively. This study provided a new insight into the strategy to enhance anthocyanin concentration in the cob and husk tissue. Visual selection for dark purple husk and cob populations segregating for purple plants was effective at boosting anthocyanin levels and antioxidant activity.

Author Contributions: Conceptualization, P.K., K.L. (Khomsorn Lomthaisong), K.L. (Kamol Lertrat), B.H. and B.S.; formal analysis, P.K., K.L. (Khomsorn Lomthaisong), M.P.S. and B.S.; methodology, P.K., K.L. (Khomsorn Lomthaisong), B.H. and B.S.; writing—original draft, P.K. and B.S.; writing-review \& editing, K.L. (Khomsorn Lomthaisong), K.L. (Kamol Lertrat) B.H. and M.P.S. All authors have read and agreed to the published version of the manuscript.

Funding: The Thailand Research Fund through the Royal Golden Jubilee Ph.D. Program (Grant No PHD/0014/2557).

Acknowledgments: The study was funded by the Thailand Research Fund through the Royal Golden Jubilee Ph.D. Program (Grant No PHD/0014/2557) and the Senior Research Scholar Project of Sanun Jogloy (Project no. RTA6180002). The authors would like to thank the National Science and Technology Development Agency through the National Center for Genetic Engineering and Biotechnology, Bangkok, Thailand (Grant No P-17-51695) and the Plant Breeding Research Center for Sustainable Agriculture, Faculty of Agriculture, Khon Kaen University, Thailand. The materials were supported by the Nakhon Sawan Field Crops Research Center, Department of Agriculture, Thailand. The authors wish to thank Abil Dermail for helpful discussions. This research was supported in part by the U.S. Department of Agriculture, Agricultural Research Service. USDA is an equal opportunity employer. Mention of trade names or commercial products in this report is solely for the purpose of providing specific information and does not imply recommendation or endorsement by the U.S. Department of Agriculture.

Conflicts of Interest: The authors declare no conflict of interest. The founding sponsors had no role in the design of the study; in the collection, analyses or interpretation of data; in the writing of the manuscript and in the decision to publish the results. 


\section{Appendix A}
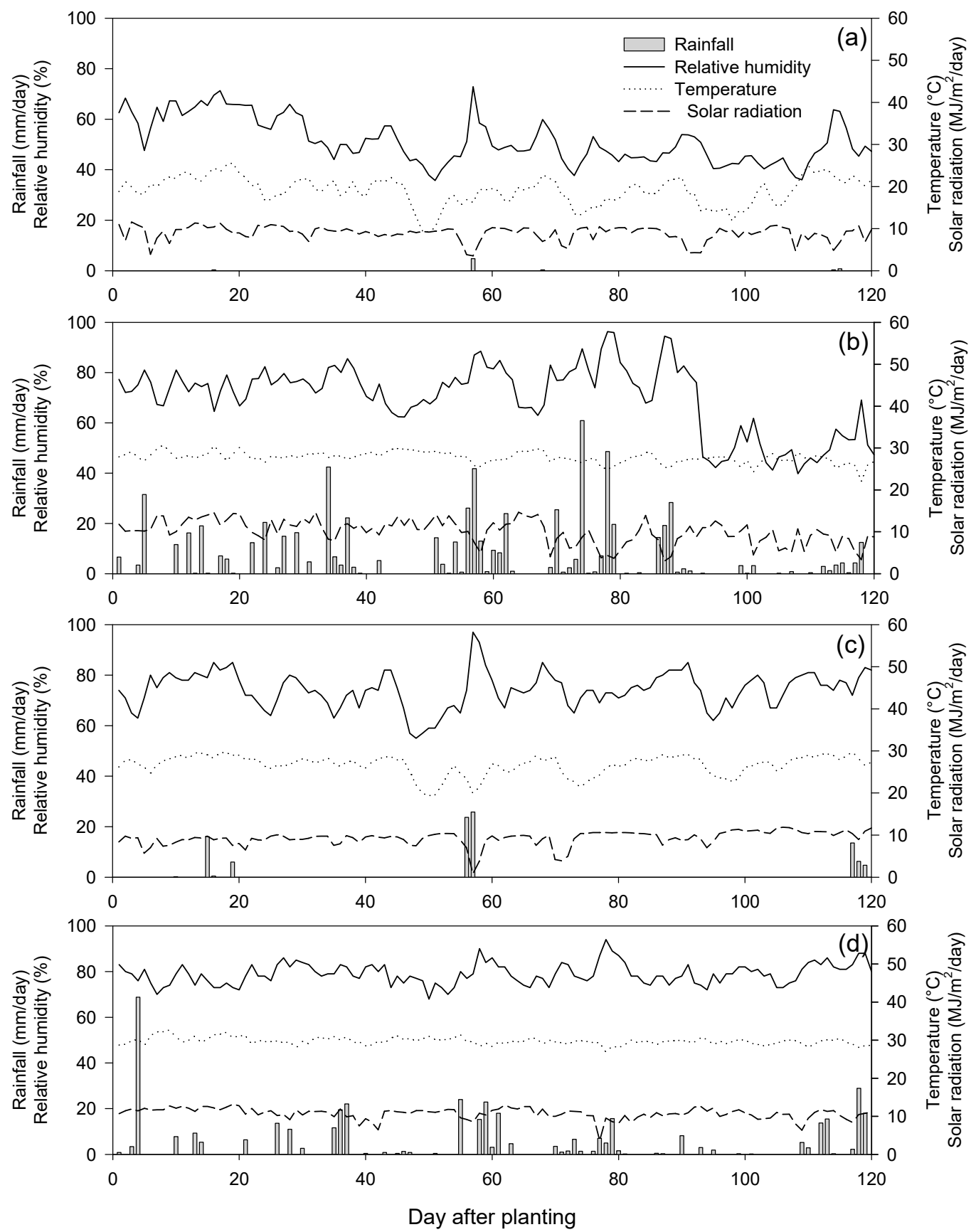

Figure A1. Rainfall, relative humidity, temperature and solar radiation during the crops growth at four environments. (a) Khon Kaen in the dry season 2017/2018, (b) Khon Kaen in the rainy season 2018, (c) Uthai Thani in the dry season 2017/2018 and (d) Uthai Thani in the rainy season 2018. 
Table A1. Means for grain yield and husk mass of (A to E) five populations and (C0 to C4) five cycles evaluated in four environments.

\begin{tabular}{|c|c|c|c|c|c|c|c|c|c|}
\hline \multirow[t]{2}{*}{ Population } & \multirow[t]{2}{*}{ Cycle } & \multicolumn{4}{|c|}{$\begin{array}{l}\text { Grain Yield } \\
\left(\mathrm{kg} \mathrm{ha}^{-1}\right)\end{array}$} & \multicolumn{4}{|c|}{$\begin{array}{l}\text { Husk Mass } \\
\left(\text { kg ha }^{-1}\right)\end{array}$} \\
\hline & & E1 & E2 & E3 & E4 & E1 & E2 & E3 & E4 \\
\hline \multirow[t]{5}{*}{ A } & $\mathrm{CO}$ & $7031 \mathrm{~cd}^{1}$ & $6562 c-f$ & $7213 b-f$ & $7643 a$ & $1000 c-e$ & $825 \mathrm{ab}$ & $752 \mathrm{e}-\mathrm{g}$ & $782 \mathrm{~b}-\mathrm{g}$ \\
\hline & $\mathrm{C} 1$ & $7660 a$ & $7049 a-d$ & $7906 a-c$ & $7668 \mathrm{a}$ & $1033 b-d$ & $733 \mathrm{~b}-\mathrm{e}$ & $880 \mathrm{~b}-\mathrm{d}$ & $723 e^{-g}$ \\
\hline & $\mathrm{C} 2$ & $7667 a$ & $7233 a$ & $7882 a-c$ & 7568ab & $1017 \mathrm{~b}-\mathrm{e}$ & $719 c-e$ & 954ab & $745 c-g$ \\
\hline & $\mathrm{C} 3$ & $7660 a$ & $6827 \mathrm{a}-\mathrm{e}$ & $6618 \mathrm{c}-\mathrm{g}$ & $7093 a-e$ & $1024 b-d$ & $777 a-e$ & $904 b c$ & $735 d-g$ \\
\hline & $\mathrm{C} 4$ & 7479ab & $6027 f$ & $7633 a-d$ & $7137 \mathrm{a}-\mathrm{e}$ & $1108 \mathrm{ab}$ & $789 a-d$ & $800 c-f$ & $775 b-g$ \\
\hline $\mathrm{b}$ & & $90 \mathrm{~ns}$ & $-129 n s$ & $-45 n s$ & $-159 *$ & $21 \mathrm{~ns}$ & $-3 \mathrm{~ns}$ & $12 \mathrm{~ns}$ & $-0.2 \mathrm{~ns}$ \\
\hline $\mathrm{r}$ & & $0.27 \mathrm{~ns}$ & $0.19 \mathrm{~ns}$ & $0.02 \mathrm{~ns}$ & $0.79^{*}$ & $0.61 \mathrm{~ns}$ & $0.01 \mathrm{~ns}$ & $0.06 \mathrm{~ns}$ & $0.00 \mathrm{~ns}$ \\
\hline \multirow[t]{5}{*}{ B } & $\mathrm{CO}$ & 6856de & $6581 b-f$ & 8131ab & $7376 a$ & $1087 b c$ & $809 a-b$ & $838 b-e$ & $741 \mathrm{c}-\mathrm{g}$ \\
\hline & $\mathrm{C} 1$ & $6943 d$ & $7196 a-c$ & $8622 a$ & $7702 a$ & $1118 \mathrm{ab}$ & $764 a-e$ & $842 \mathrm{~b}-\mathrm{e}$ & $912 a^{\circ}$ \\
\hline & $\mathrm{C} 2$ & $7265 a-d$ & $6665 a-f$ & $7358 \mathrm{a}-\mathrm{e}$ & $7630 a$ & $1071 b c$ & $796 a-d$ & $760 d-g$ & $761 b-g$ \\
\hline & $\mathrm{C} 3$ & $6904 d$ & $6507 d-f$ & $6696 c-g$ & $7155 a-e$ & $1115 \mathrm{ab}$ & 703de & $900 \mathrm{bc}$ & $765 b-g$ \\
\hline & $\mathrm{C} 4$ & $6979 \mathrm{~cd}$ & 6893a-e & $6590 c-g$ & $7323 a-d$ & $1100 \mathrm{a}-\mathrm{c}$ & $797 a-d$ & $890 \mathrm{bc}$ & $817 \mathrm{a}-\mathrm{e}$ \\
\hline $\mathrm{b}$ & & $21 \mathrm{~ns}$ & $-7 \mathrm{~ns}$ & $-501 *$ & $65 n s$ & $2 \mathrm{~ns}$ & $-9 \mathrm{~ns}$ & $16 \mathrm{~ns}$ & 1ns \\
\hline $\mathrm{r}$ & & $0.04 \mathrm{~ns}$ & $0.00 \mathrm{~ns}$ & $0.80 *$ & $0.21 \mathrm{~ns}$ & $0.03 \mathrm{~ns}$ & $0.10 \mathrm{~ns}$ & $0.21 \mathrm{~ns}$ & $0.00 \mathrm{~ns}$ \\
\hline \multirow[t]{5}{*}{$\mathrm{C}$} & $\mathrm{CO}$ & 5634hi & $6476 \mathrm{~d}-\mathrm{f}$ & $6732 c-g$ & $6652 e$ & $840 f$ & $736 a-e$ & $800 \mathrm{c}-\mathrm{f}$ & $831 a-c$ \\
\hline & $\mathrm{C} 1$ & $6171 \mathrm{fg}$ & 6907a-e & $7198 b-f$ & $7502 \mathrm{ab}$ & 950de & $804 a-d$ & $897 \mathrm{bc}$ & $844 \mathrm{ab}$ \\
\hline & $\mathrm{C} 2$ & $6095 \mathrm{fg}$ & $7026 a-e$ & $6231 \mathrm{e}-\mathrm{g}$ & $6935 b-e$ & $914 \mathrm{ef}$ & $840 a$ & $817 \mathrm{c}-\mathrm{e}$ & $766 b-g$ \\
\hline & $\mathrm{C} 3$ & $5507 i$ & $6040 \mathrm{f}$ & $6895 \mathrm{~b}-\mathrm{g}$ & 6713de & 952de & $680 \mathrm{e}$ & $833 b-e$ & $769 b-g$ \\
\hline & $\mathrm{C} 4$ & $6938 d$ & $6534 \mathrm{e}-\mathrm{f}$ & $6959 b-g$ & 6717de & $1120 \mathrm{ab}$ & $781 a-e$ & $850 b-e$ & $742 \mathrm{c}-\mathrm{g}$ \\
\hline $\mathrm{b}$ & & $194 \mathrm{~ns}$ & $-75 \mathrm{~ns}$ & $15 \mathrm{~ns}$ & $-66 n s$ & $56 \mathrm{~ns}$ & $-3 \mathrm{~ns}$ & $4 \mathrm{~ns}$ & $-25^{*}$ \\
\hline $\mathrm{r}$ & & $0.30 \mathrm{~ns}$ & $0.09 \mathrm{~ns}$ & $0.00 \mathrm{~ns}$ & $0.09 \mathrm{~ns}$ & $0.75 \mathrm{~ns}$ & $0.01 \mathrm{~ns}$ & $0.02 \mathrm{~ns}$ & $0.81^{*}$ \\
\hline \multirow[t]{5}{*}{$\mathrm{D}$} & $\mathrm{CO}$ & 7044cd & $6655 a-f$ & $6973 b-g$ & 7510ab & $1025 b-d$ & $807 a-d$ & $615 \mathrm{~h}$ & $716 \mathrm{fg}$ \\
\hline & $\mathrm{C} 1$ & $6268 f g$ & 6798a-e & $7177 b-f$ & $7212 \mathrm{a}-\mathrm{e}$ & $1077 b c$ & $789 a-d$ & $780 c-f$ & $721 \mathrm{e}-\mathrm{g}$ \\
\hline & $\mathrm{C} 2$ & $7206 b-d$ & $6650 a-f$ & $6735 c-9$ & $7255 a-e$ & $1029 b-d$ & $749 a-e$ & $687 f-h$ & $710 \mathrm{~g}$ \\
\hline & $\mathrm{C} 3$ & $6001 \mathrm{gh}$ & 6377ef & $5889 \mathrm{fg}^{\circ}$ & $6798 \mathrm{c}-\mathrm{e}$ & $1080 \mathrm{bc}$ & $812 a-c$ & $643 \mathrm{gh}$ & $763 b-g$ \\
\hline & $\mathrm{C} 4$ & $6450 \mathrm{ef}$ & 7215ab & $7246 b-f$ & $\begin{array}{c}7122 \\
\mathrm{a}-\mathrm{e}\end{array}$ & $1195 a$ & $782 a-e$ & $848 b-e$ & $794 b-g$ \\
\hline $\mathrm{b}$ & & $-146 n s$ & 70ns & $-74 n s$ & $-119 \mathrm{~ns}$ & $34 n s$ & Ons & $33 n s$ & $20 \mathrm{~ns}$ \\
\hline $\mathrm{r}$ & & $0.20 \mathrm{~ns}$ & $0.13 \mathrm{~ns}$ & $0.05 \mathrm{~ns}$ & $0.54 \mathrm{~ns}$ & $0.63 \mathrm{~ns}$ & $0.03 \mathrm{~ns}$ & $0.29 \mathrm{~ns}$ & $0.74 \mathrm{~ns}$ \\
\hline \multirow[t]{5}{*}{ E } & $\mathrm{C} 0$ & 6441ef & $6504 d-f$ & $7548 \mathrm{a}-\mathrm{e}$ & $7365 a-d$ & $993 c-e$ & $743 a-e$ & $785 c-f$ & $766 b-g$ \\
\hline & $\mathrm{C} 1$ & 6998cd & $6531 \mathrm{~d}-\mathrm{f}$ & $6568 c-g$ & $7700 a$ & $1055 b-d$ & $729 \mathrm{~b}-\mathrm{e}$ & $830 b-e$ & $776 \mathrm{~b}-\mathrm{g}$ \\
\hline & $\mathrm{C} 2$ & $6897 d$ & 7214ab & $6449 d-g$ & $7417 a-c$ & $1122 \mathrm{ab}$ & $763 a-e$ & $883 b-d$ & $726 \mathrm{e}-\mathrm{g}$ \\
\hline & $\mathrm{C} 3$ & $7380 a-c$ & 6606a-f & $5678 \mathrm{~g}$ & $7671 \mathrm{a}$ & $1113 \mathrm{ab}$ & $792 a-d$ & $1038 \mathrm{a}$ & $823 a-d$ \\
\hline & $\mathrm{C} 4$ & 7589ab & 6821a-e & $6486 \mathrm{~d}-\mathrm{g}$ & $7646 a$ & $1100 a-c$ & $792 a-d$ & $868 \mathrm{~b}-\mathrm{e}$ & $810 \mathrm{~b}-\mathrm{f}$ \\
\hline $\mathrm{b}$ & & $268 *$ & 71ns & $-301 \mathrm{~ns}$ & $53 \mathrm{~ns}$ & 27ns & $16^{*}$ & $37 \mathrm{~ns}$ & $13 \mathrm{~ns}$ \\
\hline $\mathrm{r}$ & & 0.90 * & $0.14 \mathrm{~ns}$ & $0.51 \mathrm{~ns}$ & $0.29 \mathrm{~ns}$ & $0.65 \mathrm{~ns}$ & $0.80 *$ & $0.38 \mathrm{~ns}$ & $0.31 \mathrm{~ns}$ \\
\hline \multirow{3}{*}{ Check var. } & KND & 6676 & 6761 & 7490 & 6600 & 1102 & 667 & 697 & 772 \\
\hline & KGW & 7330 & 6628 & 6164 & 7309 & 1097 & 512 & 643 & 591 \\
\hline & P339 & 9297 & 10,773 & 12,419 & 10,995 & 1687 & 1545 & 1257 & 1660 \\
\hline \multicolumn{10}{|c|}{$\begin{array}{l}\text { ns and * not significant and significant at } 0.05 \text { probability levels; }{ }^{1} \text { means in a column followed by the same letter are } \\
\text { not significantly different at } 0.05 \text { probability levels; b-response to selection; } r \text {-correlation coefficient; E1—Khon } \\
\text { Kaen, dry season; E2-Khon Kaen, rainy season; E3-Uthai Thani, dry season; E4-Uthai Thani, rainy season. }\end{array}$} \\
\hline \multirow{2}{*}{ Population } & \multirow{2}{*}{ Cycle } & \multicolumn{4}{|c|}{$\begin{array}{l}\text { Cob Mass } \\
\left(\mathrm{kg} \mathrm{ha}^{-1}\right)\end{array}$} & \multicolumn{4}{|c|}{$\begin{array}{l}\text { Anthesis Day } \\
\text { (DAP) }\end{array}$} \\
\hline & & E1 & E2 & E3 & E4 & E1 & E2 & E3 & E4 \\
\hline \multirow[t]{5}{*}{ A } & $\mathrm{CO}$ & $1017 \mathrm{~b}-\mathrm{e}^{1}$ & $828 a-c$ & $853 c d$ & $892 a-c$ & $60 \mathrm{ab}$ & $54 \mathrm{~b}-\mathrm{d}$ & $55 \mathrm{~cd}$ & $52 a-d$ \\
\hline & $\mathrm{C} 1$ & $1067 a-c$ & $833 a-c$ & $946 a-d$ & $838 \mathrm{a}-\mathrm{d}$ & $59 \mathrm{~cd}$ & $53 d-g$ & $54 \mathrm{~d}-\mathrm{f}$ & $52 \mathrm{c}-\mathrm{e}$ \\
\hline & $\mathrm{C} 2$ & 1094ab & $777 \mathrm{bc}$ & $899 b-d$ & $819 b-d$ & $58 \mathrm{~d}-\mathrm{f}$ & $53 \mathrm{e}-\mathrm{g}$ & $54 \mathrm{e}-\mathrm{g}$ & 51de \\
\hline & $\mathrm{C} 3$ & $1115 \mathrm{ab}$ & $835 a-c$ & $955 a-d$ & $866 a-d$ & $58 \mathrm{e}-\mathrm{g}$ & $52 \mathrm{~g}$ & $54 \mathrm{e}-\mathrm{g}$ & $51 \mathrm{ef}$ \\
\hline & $\mathrm{C} 4$ & $1117 \mathrm{ab}$ & $870 \mathrm{ab}$ & $986 a-c$ & $815 b-d$ & $56 \mathrm{i}-\mathrm{O}$ & $53 \mathrm{fg}$ & $52 i^{\circ}$ & $50 \mathrm{f}$ \\
\hline $\mathrm{b}$ & & $25 *$ & $9 \mathrm{~ns}$ & $28 \mathrm{~ns}$ & $-13 n s$ & $-1 * *$ & $-0.4^{*}$ & -1 * & $-1 * *$ \\
\hline $\mathrm{r}$ & & $0.89 *$ & $0.17 \mathrm{~ns}$ & $0.69 \mathrm{~ns}$ & $0.37 \mathrm{~ns}$ & $0.97^{* *}$ & $0.80 *$ & 0.89 * & 0.96 ** \\
\hline
\end{tabular}


Table A2. Cont.

\begin{tabular}{|c|c|c|c|c|c|c|c|c|c|}
\hline \multirow[t]{2}{*}{ Population } & \multirow[t]{2}{*}{ Cycle } & \multicolumn{4}{|c|}{$\begin{array}{l}\text { Cob Mass } \\
\left(\mathrm{kg} \mathrm{ha}^{-1}\right)\end{array}$} & \multicolumn{4}{|c|}{$\begin{array}{l}\text { Anthesis Day } \\
\text { (DAP) }\end{array}$} \\
\hline & & E1 & E2 & E3 & E4 & E1 & E2 & E3 & E4 \\
\hline \multirow[t]{5}{*}{ B } & $\mathrm{CO}$ & $1028 \mathrm{a}-\mathrm{e}$ & $890 \mathrm{ab}$ & $918 a-d$ & $809 b-d$ & $59 b c$ & $54 b-d$ & $56 b c$ & $53 a-c$ \\
\hline & $\mathrm{C} 1$ & $1095 a b$ & $828 a-c$ & $913 a-d$ & $888 \mathrm{a}-\mathrm{c}$ & $59 c-e$ & $54 b-d$ & $55 c-e$ & $52 b-e$ \\
\hline & $\mathrm{C} 2$ & $1088 \mathrm{ab}$ & $750 c$ & $842 d$ & $846 a-d$ & $57 g-i$ & $54 \mathrm{~b}-\mathrm{e}$ & $53 \mathrm{f}-\mathrm{h}$ & $52 c-e$ \\
\hline & C3 & $1108 \mathrm{ab}$ & $777 \mathrm{bc}$ & $897 b-d$ & $805 b-d$ & $56 \mathrm{~h}-\mathrm{j}$ & $53 e-g$ & $53 g-i$ & 51de \\
\hline & $\mathrm{C} 4$ & $1128 \mathrm{a}$ & $791 a-c$ & $976 a-d$ & $905 \mathrm{ab}$ & $55 \mathrm{j}-\mathrm{L}$ & $53 \mathrm{fg}$ & $52 \mathrm{i}$ & $50 f$ \\
\hline$b$ & & $21 *$ & $-25 n s$ & 10ns & $11 \mathrm{~ns}$ & $-1 * *$ & $-1 *$ & $-1 * *$ & $-1 * *$ \\
\hline $\mathrm{r}$ & & $0.81 *$ & $0.53 \mathrm{~ns}$ & $0.11 \mathrm{~ns}$ & $0.15 \mathrm{~ns}$ & $0.95^{* *}$ & $0.89 *$ & $0.98^{* *}$ & $0.92 * *$ \\
\hline \multirow[t]{5}{*}{$\mathrm{C}$} & $\mathrm{CO}$ & $935 e$ & $860 a-c$ & $905 a-d$ & $831 b-d$ & $60 \mathrm{ab}$ & $55 b$ & $56 a b$ & $53 \mathrm{ab}$ \\
\hline & $\mathrm{C} 1$ & 946de & $822 a-c$ & $917 a-d$ & $942 \mathrm{a}$ & $59 \mathrm{~cd}$ & $55 \mathrm{bc}$ & $55 \mathrm{~cd}$ & $52 a-d$ \\
\hline & $\mathrm{C} 2$ & $1042 a-d$ & $797 a-c$ & $1030 a-b$ & $825 b-d$ & $57 f-h$ & $54 c-f$ & $54 \mathrm{e}-\mathrm{g}$ & $52 a-b$ \\
\hline & C3 & $1033 a-e$ & $819 a-c$ & $948 \mathrm{a}-\mathrm{d}$ & $872 a-d$ & $56 \mathrm{~h}-\mathrm{j}$ & $53 d-g$ & $53 \mathrm{f}-\mathrm{h}$ & $52 a-d$ \\
\hline & $\mathrm{C} 4$ & 1100ab & $869 \mathrm{ab}$ & $914 a-d$ & 770d & 551 & $53 e-g$ & $52 \mathrm{i}$ & $52 b-e$ \\
\hline$b$ & & $42 *$ & $2 \mathrm{~ns}$ & 5ns & $-19 n s$ & $-1 * *$ & $-1 * *$ & $-1 * *$ & $-0.2 n s$ \\
\hline $\mathrm{r}$ & & $0.90 *$ & $0.01 \mathrm{~ns}$ & $0.02 \mathrm{~ns}$ & $0.27 \mathrm{~ns}$ & $1.00^{* *}$ & $0.96^{* *}$ & $0.97^{* *}$ & $0.75 \mathrm{~ns}$ \\
\hline \multirow[t]{5}{*}{$\mathrm{D}$} & $\mathrm{CO}$ & 950de & $825 a-c$ & $837 d$ & $793 \mathrm{~cd}$ & $60 \mathrm{ab}$ & $56 a$ & $57 \mathrm{ab}$ & $53 a$ \\
\hline & $\mathrm{C} 1$ & $980 c-e$ & $902 a$ & $919 a-d$ & $843 a-d$ & $59 c-e$ & $54 b-d$ & $55 c-e$ & $53 \mathrm{ab}$ \\
\hline & $\mathrm{C} 2$ & $1017 \mathrm{~b}-\mathrm{e}$ & $825 a-c$ & $921 a-d$ & $870 a-d$ & $57 \mathrm{f}-\mathrm{i}$ & $54 \mathrm{~b}-\mathrm{e}$ & $53 \mathrm{f}-\mathrm{h}$ & $53 a-c$ \\
\hline & C3 & $1083 \mathrm{ab}$ & $777 b c$ & $925 a-d$ & $819 b-d$ & 56i-k & $54 c-f$ & $53 g-i$ & $53 a-c$ \\
\hline & $\mathrm{C} 4$ & 1119a & $837 a-c$ & $959 a-d$ & $897 a-c$ & 551 & $54 c-f$ & 52hi & $52 c-e$ \\
\hline $\mathrm{b}$ & & $44^{* *}$ & $-10 \mathrm{~ns}$ & 25ns & 19ns & $-1 * *$ & $-1 * *$ & $-1 *$ & -0.3 * \\
\hline $\mathrm{r}$ & & $0.98^{* *}$ & $0.13 \mathrm{~ns}$ & $0.77^{*}$ & $0.51 \mathrm{~ns}$ & $0.99^{* *}$ & $0.72 * *$ & $0.91 *$ & $0.86 *$ \\
\hline \multirow[t]{5}{*}{$\mathrm{E}$} & $\mathrm{CO}$ & $973 c-e$ & $883 \mathrm{ab}$ & $937 a-d$ & $897 a-c$ & $61 a$ & $55 b$ & $57 a$ & $53 \mathrm{ab}$ \\
\hline & $\mathrm{C} 1$ & $1038 \mathrm{a}-\mathrm{d}$ & $820 a-c$ & $1043 a$ & $901 a-c$ & $59 c-e$ & $54 \mathrm{~b}-\mathrm{e}$ & $56 a b$ & $52 b-e$ \\
\hline & $\mathrm{C} 2$ & $1068 \mathrm{a}-\mathrm{c}$ & $794 a-c$ & $848 \mathrm{~cd}$ & $898 a-c$ & $57 \mathrm{f}-\mathrm{h}$ & $53 d-g$ & $55 c-e$ & $52 \mathrm{~b}-\mathrm{e}$ \\
\hline & C3 & $1028 \mathrm{a}-\mathrm{e}$ & $779 b c$ & $938 a-d$ & $821 b-d$ & 56h-j & $53 \mathrm{fg}$ & $54 \mathrm{e}-\mathrm{g}$ & $52 c-e$ \\
\hline & $\mathrm{C} 4$ & $1122 a$ & $862 a-c$ & $988 \mathrm{a}-\mathrm{c}$ & $850 a-d$ & $55 \mathrm{kl}$ & $53 \mathrm{e}-\mathrm{g}$ & $53 g-i$ & 51ef \\
\hline$b$ & & $29 \mathrm{~ns}$ & $-8 n s$ & $-0.2 \mathrm{~ns}$ & $-17 \mathrm{~ns}$ & $-1 * *$ & $-1 *$ & $-1 * *$ & -0.4 * \\
\hline $\mathrm{r}$ & & $0.69 \mathrm{~ns}$ & $0.09 \mathrm{~ns}$ & $0.00 \mathrm{~ns}$ & $0.58 \mathrm{~ns}$ & $0.97^{* *}$ & $0.83 *$ & $0.98^{* *}$ & $0.90 *$ \\
\hline \multirow{3}{*}{ Check var. } & KND & 1155 & 877 & 1073 & 798 & 50 & 42 & 46 & 42 \\
\hline & KGW & 1127 & 744 & 868 & 822 & 51 & 46 & 49 & 45 \\
\hline & P339 & 1273 & 1150 & 1210 & 1229 & 64 & 57 & 62 & 56 \\
\hline
\end{tabular}

ns, ${ }^{*}$ and ${ }^{* *}$ not significant and significant at 0.05 and 0.01 probability levels, respectively; ${ }^{1}$ means in a column followed by the same letter are not significantly different at 0.05 probability levels; $b$-response to selection; $\mathrm{r}$ - correlation coefficient; DAP_-days after planting; E1—Khon Kaen, dry season; E2—Khon Kaen, rainy season; E3-Uthai Thani, dry season; E4-Uthai Thani, rainy season.

Table A3. Means for plant height and ear height of (A-E) five populations and (CO-C4) five cycles evaluated in four environments.

\begin{tabular}{|c|c|c|c|c|c|c|c|c|c|}
\hline \multirow[t]{2}{*}{ Population } & \multirow[t]{2}{*}{ Cycle } & \multicolumn{4}{|c|}{$\begin{array}{l}\text { Plant Height } \\
\text { (cm) }\end{array}$} & \multicolumn{4}{|c|}{$\begin{array}{c}\text { Ear Height } \\
(\mathrm{cm})\end{array}$} \\
\hline & & E1 & E2 & E3 & $\mathrm{E} 4$ & E1 & E2 & E3 & E4 \\
\hline \multirow[t]{5}{*}{$\mathrm{A}$} & $\mathrm{CO}$ & $198.3 c-h^{1}$ & $162.0 \mathrm{a}-\mathrm{e}$ & $190.7 \mathrm{~b}-\mathrm{f}$ & $195.3 a-f$ & $101.3 \mathrm{e}-\mathrm{h}$ & $85.3 a-d$ & $101.3 b-\mathrm{e}$ & $104.0 \mathrm{a}-\mathrm{c}$ \\
\hline & $\mathrm{C} 1$ & $187.7 \mathrm{i}$ & $169.0 \mathrm{a}-\mathrm{e}$ & 183.7ef & $190.7 c-i$ & 99.3f-h & $80.0 \mathrm{~b}-\mathrm{h}$ & $101.3 b-e$ & $102.0 \mathrm{a}-\mathrm{e}$ \\
\hline & $\mathrm{C} 2$ & $198.7 c-h$ & $170.0 \mathrm{a}-\mathrm{e}$ & $189.3 b-f$ & $184.3 \mathrm{f}-\mathrm{j}$ & $104.0 \mathrm{~b}-\mathrm{h}$ & $78.3 c-j$ & $103.7 \mathrm{a}-\mathrm{e}$ & $89.3 \mathrm{~h}-\mathrm{i}$ \\
\hline & $\mathrm{C} 3$ & $204.0 \mathrm{a}-\mathrm{f}$ & $159.7 \mathrm{c}-\mathrm{e}$ & $190.0 b-f$ & $183.7 f-j$ & $102.3 c-h$ & $74.0 \mathrm{f}-\mathrm{j}$ & $100.0 \mathrm{~b}-\mathrm{e}$ & $91.0 \mathrm{f}-\mathrm{h}$ \\
\hline & $\mathrm{C} 4$ & $207.7 a-c$ & $163.7 \mathrm{a}-\mathrm{e}$ & 196.3a-f & $184.7 \mathrm{e}-\mathrm{j}$ & $103.7 b-h$ & $74.3 f-j$ & $102.0 \mathrm{~b}-\mathrm{e}$ & $96.0 \mathrm{~b}-\mathrm{g}$ \\
\hline $\mathrm{b}$ & & $3.5 \mathrm{~ns}$ & $-6.0 \mathrm{~ns}$ & $1.8 \mathrm{~ns}$ & $-2.8^{*}$ & $0.8 \mathrm{~ns}$ & $-2.8^{*}$ & $0.0 \mathrm{~ns}$ & $-2.7 \mathrm{~ns}$ \\
\hline $\mathrm{r}$ & & $0.54 \mathrm{~ns}$ & $0.04 \mathrm{~ns}$ & $0.38 \mathrm{~ns}$ & $0.77^{*}$ & $0.41 \mathrm{~ns}$ & $0.91 *$ & $0.00 \mathrm{~ns}$ & $0.43 \mathrm{~ns}$ \\
\hline \multirow[t]{5}{*}{ B } & $\mathrm{CO}$ & $203.0 a-g$ & $172.0 \mathrm{a}-\mathrm{c}$ & $197.7 \mathrm{a}-\mathrm{e}$ & $196.0 \mathrm{a}-\mathrm{f}$ & $98.0 \mathrm{~g}-\mathrm{i}$ & $87.0 \mathrm{a}-\mathrm{c}$ & $102.7 \mathrm{a}-\mathrm{e}$ & $100.3 a-f$ \\
\hline & $\mathrm{C} 1$ & $196.0 \mathrm{~d}-\mathrm{i}$ & $169.3 a-e$ & 191.0b-f & 191.3b-h & $101.7 \mathrm{~d}-\mathrm{h}$ & $82.3 a-f$ & $99.0 c-e$ & $97.3 b-g$ \\
\hline & $\mathrm{C} 2$ & $196.3 d-i$ & $169.3 a-e$ & $182.0 f$ & $176.7 \mathrm{j}$ & $91.7 \mathrm{i}$ & $69.3 \mathrm{jk}$ & 96.3de & $78.7 \mathrm{jk}$ \\
\hline & $\mathrm{C} 3$ & 189.0hi & $158.0 \mathrm{c}-\mathrm{e}$ & $189.3 b-f$ & $181.0 \mathrm{~h}-\mathrm{j}$ & $90.7 \mathrm{i}$ & $64.0 \mathrm{k}$ & $92.3 \mathrm{e}$ & $75.0 \mathrm{k}$ \\
\hline & $\mathrm{C} 4$ & $202.0 \mathrm{a}-\mathrm{g}$ & $172.3 a-c$ & 195.3a-f & $197.7 \mathrm{a}-\mathrm{d}$ & $103.3 b-h$ & $79.3 c-i$ & $100.3 b-e$ & $101.0 \mathrm{a}-\mathrm{e}$ \\
\hline $\mathrm{b}$ & & $-0.9 \mathrm{~ns}$ & $-1.1 \mathrm{~ns}$ & $-0.6 \mathrm{~ns}$ & $-0.7 \mathrm{~ns}$ & $-0.03 \mathrm{~ns}$ & $-3.4 \mathrm{~ns}$ & -1.1ns & $-2.1 \mathrm{~ns}$ \\
\hline $\mathrm{r}$ & & $0.06 \mathrm{~ns}$ & $0.08 \mathrm{~ns}$ & $0.03 \mathrm{~ns}$ & $0.01 \mathrm{~ns}$ & $0.00 \mathrm{~ns}$ & $0.32 \mathrm{~ns}$ & $0.20 \mathrm{~ns}$ & $0.07 \mathrm{~ns}$ \\
\hline
\end{tabular}


Table A3. Cont.

\begin{tabular}{|c|c|c|c|c|c|c|c|c|c|}
\hline \multirow[t]{2}{*}{ Population } & \multirow[t]{2}{*}{ Cycle } & \multicolumn{4}{|c|}{$\begin{array}{l}\text { Plant Height } \\
\text { (cm) }\end{array}$} & \multicolumn{4}{|c|}{$\begin{array}{c}\text { Ear Height } \\
\text { (cm) }\end{array}$} \\
\hline & & E1 & E2 & E3 & E4 & E1 & E2 & E3 & E4 \\
\hline \multirow[t]{5}{*}{$C$} & $\mathrm{CO}$ & $204.7 \mathrm{a}-\mathrm{e}$ & $172.0 \mathrm{a}-\mathrm{c}$ & $207.7 a$ & $205.0 \mathrm{a}$ & $104.0 \mathrm{~b}-\mathrm{h}$ & $81.7 \mathrm{a}-\mathrm{g}$ & $109.3 a-c$ & 104.7ab \\
\hline & $\mathrm{C} 1$ & 205.3a-d & $171.0 \mathrm{a}-\mathrm{d}$ & 203.7ab & $201.0 \mathrm{a}-\mathrm{c}$ & $110.0 \mathrm{ab}$ & $87.0 \mathrm{a}-\mathrm{c}$ & 111.3ab & $103.7 \mathrm{a}-\mathrm{d}$ \\
\hline & $\mathrm{C} 2$ & $206.7 a-c$ & $154.3 \mathrm{e}$ & $185.0 \mathrm{~d}-\mathrm{f}$ & $174.3 \mathrm{j}$ & $107.7 \mathrm{~b}-\mathrm{e}$ & $70.3 \mathrm{i}-\mathrm{k}$ & $100.7 \mathrm{~b}-\mathrm{e}$ & 78.7jk \\
\hline & $\mathrm{C} 3$ & $207.3 a-c$ & $160.0 \mathrm{~b}-\mathrm{e}$ & $198.7 \mathrm{a}-\mathrm{d}$ & $184.3 \mathrm{f}-\mathrm{j}$ & $105.3 \mathrm{~b}-\mathrm{g}$ & $72.0 \mathrm{~h}-\mathrm{k}$ & 103.3a-e & $80.3 \mathrm{i}-\mathrm{k}$ \\
\hline & $\mathrm{C} 4$ & $205.7 \mathrm{a}-\mathrm{d}$ & $158.7 \mathrm{c}-\mathrm{e}$ & $200.0 a-c$ & $185.3 \mathrm{~d}-\mathrm{j}$ & $105.7 \mathrm{~b}-\mathrm{f}$ & $75.7 \mathrm{e}-\mathrm{j}$ & $114.0 \mathrm{a}$ & $92.7 \mathrm{e}-\mathrm{h}$ \\
\hline$b$ & & $0.4 \mathrm{~ns}$ & $-3.8 \mathrm{~ns}$ & $-2.0 \mathrm{~ns}$ & $-5.6 n s$ & $-0.1 \mathrm{~ns}$ & $-2.7 \mathrm{~ns}$ & $0.1 \mathrm{~ns}$ & $-4.7 \mathrm{~ns}$ \\
\hline $\mathrm{r}$ & & $0.35 \mathrm{~ns}$ & $0.57 \mathrm{~ns}$ & $0.14 \mathrm{~ns}$ & $0.49 \mathrm{~ns}$ & $0.01 \mathrm{~ns}$ & $0.38 \mathrm{~ns}$ & $0.00 \mathrm{~ns}$ & $0.37 \mathrm{~ns}$ \\
\hline \multirow[t]{5}{*}{$\mathrm{D}$} & $\mathrm{C} 0$ & $194.0 \mathrm{~g}-\mathrm{i}$ & $159.3 c-e$ & $198.7 \mathrm{a}-\mathrm{d}$ & $178.3 \mathrm{ij}$ & $107.3 b-e$ & $84.7 \mathrm{a}-\mathrm{e}$ & $114.3 a$ & $98.0 \mathrm{~b}-\mathrm{g}$ \\
\hline & $\mathrm{C} 1$ & $196.7 \mathrm{~d}-\mathrm{i}$ & $175.7 \mathrm{ab}$ & 207.3a & $200.7 a-c$ & 97.7hi & $84.0 \mathrm{a}-\mathrm{e}$ & $111.7 \mathrm{ab}$ & $101.0 \mathrm{a}-\mathrm{e}$ \\
\hline & $\mathrm{C} 2$ & $194.3 \mathrm{f}-\mathrm{i}$ & $177.7 \mathrm{a}$ & 196.3a-f & $175.7 \mathrm{j}$ & $105.3 \mathrm{~b}-\mathrm{g}$ & $76.7 \mathrm{~d}-\mathrm{j}$ & $106.7 \mathrm{a}-\mathrm{d}$ & $85.7 \mathrm{~h}-\mathrm{j}$ \\
\hline & $\mathrm{C} 3$ & $199.0 \mathrm{c}-\mathrm{g}$ & $154.7 \mathrm{e}$ & $190.3 b-f$ & $181.3 \mathrm{~g}-\mathrm{j}$ & $98.0 \mathrm{~g}-\mathrm{i}$ & $72.7 \mathrm{~g}-\mathrm{k}$ & $104.0 \mathrm{a}-\mathrm{e}$ & $94.7 \mathrm{c}-\mathrm{h}$ \\
\hline & $\mathrm{C} 4$ & $195.3 \mathrm{e}-\mathrm{i}$ & 156.0de & $197.3 a-e$ & 193.3a-h & 97.3hi & $79.7 \mathrm{c}-\mathrm{i}$ & $107.3 a-d$ & $97.0 \mathrm{~b}-\mathrm{g}$ \\
\hline $\mathrm{b}$ & & $0.5 \mathrm{~ns}$ & $-2.8 \mathrm{~ns}$ & $-2.0 \mathrm{~ns}$ & $1.1 \mathrm{~ns}$ & $-2.0 \mathrm{~ns}$ & $-2.1 \mathrm{~ns}$ & $-2.2 \mathrm{~ns}$ & $-0.8 \mathrm{~ns}$ \\
\hline $\mathrm{r}$ & & $0.15 \mathrm{~ns}$ & $0.16 \mathrm{~ns}$ & $0.26 \mathrm{~ns}$ & $0.02 \mathrm{~ns}$ & $0.42 \mathrm{~ns}$ & $0.45 \mathrm{~ns}$ & $0.69 \mathrm{~ns}$ & $0.05 \mathrm{~ns}$ \\
\hline \multirow[t]{5}{*}{$\mathrm{E}$} & $\mathrm{CO}$ & $202.7 \mathrm{a}-\mathrm{g}$ & 175.7ab & $207.0 \mathrm{a}$ & 203.7ab & $107.0 \mathrm{~b}-\mathrm{e}$ & $91.0 \mathrm{a}$ & $107.7 \mathrm{a}-\mathrm{d}$ & $108.3 a$ \\
\hline & $\mathrm{C} 1$ & $211.7 \mathrm{a}$ & $172.7 \mathrm{a}-\mathrm{c}$ & $206.3 a$ & 197.3a-e & $116.0 \mathrm{a}$ & $87.0 \mathrm{a}-\mathrm{c}$ & $110.7 \mathrm{a}-\mathrm{c}$ & $108.0 \mathrm{a}$ \\
\hline & $\mathrm{C} 2$ & $210.3 \mathrm{ab}$ & $171.7 \mathrm{a}-\mathrm{d}$ & $186.3 \mathrm{c}-\mathrm{f}$ & $176.0 \mathrm{j}$ & $109.3 a-c$ & $76.0 \mathrm{~d}-\mathrm{j}$ & $105.0 \mathrm{a}-\mathrm{d}$ & $86.3 \mathrm{~h}-\mathrm{j}$ \\
\hline & $\mathrm{C} 3$ & $207.3 a-c$ & $164.3 a-e$ & $202.3 \mathrm{ab}$ & $194.0 \mathrm{a}-\mathrm{g}$ & $107.3 \mathrm{~b}-\mathrm{e}$ & $79.0 \mathrm{c}-\mathrm{i}$ & $109.0 \mathrm{a}-\mathrm{c}$ & $94.3 \mathrm{~d}-\mathrm{h}$ \\
\hline & $\mathrm{C} 4$ & $201.0 \mathrm{~b}-\mathrm{g}$ & $175.7 \mathrm{ab}$ & $199.7 \mathrm{a}-\mathrm{c}$ & $198.0 \mathrm{a}-\mathrm{d}$ & $109.0 \mathrm{a}-\mathrm{d}$ & 89.3ab & $104.7 \mathrm{a}-\mathrm{d}$ & $103.3 a-d$ \\
\hline b & & $-1.0 \mathrm{~ns}$ & $-0.8 \mathrm{~ns}$ & $-1.9 \mathrm{~ns}$ & $-1.5 \mathrm{~ns}$ & $-0.5 \mathrm{~ns}$ & $-1.1 \mathrm{~ns}$ & $-0.8 \mathrm{~ns}$ & $-2.4 \mathrm{~ns}$ \\
\hline$r$ & & $0.07 \mathrm{~ns}$ & $0.08 \mathrm{~ns}$ & $0.12 \mathrm{~ns}$ & $0.05 \mathrm{~ns}$ & $0.04 \mathrm{~ns}$ & $0.07 \mathrm{~ns}$ & $0.22 \mathrm{~ns}$ & $0.15 \mathrm{~ns}$ \\
\hline \multirow{3}{*}{ Check var. } & KND & 196 & 178.7 & 204.7 & 203.7 & 105 & 85 & 102 & 98 \\
\hline & KGW & 215.3 & 175.7 & 214.7 & 198.3 & 109 & 82 & 99.3 & 90 \\
\hline & P339 & 207 & 173.3 & 198.3 & 174 & 112 & 87 & 116 & 96.7 \\
\hline
\end{tabular}

ns and * not significant and significant at 0.05 probability levels; ${ }^{1}$ means in a column followed by the same letter are not significantly different at 0.05 probability levels; $\mathrm{b}$ - response to selection; $r$-correlation coefficient; DAP-days after planting; E1—Khon Kaen, dry season; E2—Khon Kaen, rainy season; E3—Uthai Thani, dry season; E4-Uthai Thani, rainy season.

Table A4. Means for total anthocyanin yield (TAY) in husk and cob of (A-E) five populations and (C0-C4) five cycles evaluated in four environments.

\begin{tabular}{|c|c|c|c|c|c|c|c|c|c|}
\hline \multirow[t]{2}{*}{ Population } & \multirow[t]{2}{*}{ Cycle } & \multicolumn{4}{|c|}{$\begin{array}{c}\text { TAY in Husk } \\
(\mathrm{kg} \mathrm{CGE/DW} \mathrm{ha-1)}\end{array}$} & \multicolumn{4}{|c|}{$\begin{array}{c}\text { TAY in Cob } \\
(\mathrm{kg} \mathrm{CGE/DW} \mathrm{ha-1)}\end{array}$} \\
\hline & & E1 & E2 & E3 & E4 & E1 & E2 & E3 & E4 \\
\hline \multirow[t]{5}{*}{$\mathrm{A}$} & $\mathrm{CO}$ & $1.0 \mathrm{j}^{1}$ & 0.81 & $1.2 \mathrm{kl}$ & $1.1 \mathrm{j}$ & $1.5 \mathrm{~lm}$ & $0.5 \mathrm{~m}$ & $1.1 \mathrm{j}-1$ & $0.5 \mathrm{~m}$ \\
\hline & $\mathrm{C} 1$ & $2.9 \mathrm{i}$ & $2.1 \mathrm{jk}$ & $3.0 \mathrm{ij}$ & $2.4 \mathrm{i}$ & $2.1 \mathrm{j}-1$ & 1.51 & $1.8 \mathrm{~h}-1$ & 1.81 \\
\hline & $\mathrm{C} 2$ & $7.4 \mathrm{f}$ & $4.9 \mathrm{ef}$ & $5.8 \mathrm{~g}$ & $4.1 \mathrm{fg}$ & $4.7 \mathrm{~g}$ & $2.1 \mathrm{i}-\mathrm{k}$ & $3.9 \mathrm{fg}$ & $2.3 \mathrm{i}-1$ \\
\hline & $\mathrm{C} 3$ & $17.1 \mathrm{~d}$ & $12.9 \mathrm{~b}$ & $14.3 \mathrm{~cd}$ & 10.9de & $6.5 \mathrm{f}$ & $3.5 \mathrm{de}$ & $6.1 \mathrm{e}^{\circ}$ & $3.3 \mathrm{e}-\mathrm{g}$ \\
\hline & $\mathrm{C} 4$ & $25.0 \mathrm{a}$ & $16.0 \mathrm{a}$ & $15.6 \mathrm{bc}$ & $13.2 \mathrm{c}$ & $12.7 \mathrm{bc}$ & $4.2 b c$ & $11.5 \mathrm{~b}$ & $4.2 \mathrm{~cd}$ \\
\hline $\mathrm{b}$ & & $6.2^{* *}$ & $4.1^{* *}$ & $4.0 * *$ & $3.3^{* *}$ & $2.7^{*}$ & $1.0^{* *}$ & $2.5^{*}$ & $0.9^{* *}$ \\
\hline $\mathrm{r}$ & & $0.94 * *$ & $0.93 * *$ & $0.93^{* *}$ & $0.92 * *$ & $0.89 *$ & $0.99 * *$ & 0.90 * & $0.98^{* *}$ \\
\hline \multirow[t]{5}{*}{ B } & $\mathrm{CO}$ & $0.6 j$ & $1.1 \mathrm{kl}$ & 1.01 & $0.9 j$ & $1.31 \mathrm{~m}$ & $0.6 \mathrm{~m}$ & $1.1 \mathrm{j}-1$ & $0.4 \mathrm{~m}$ \\
\hline & $\mathrm{C} 1$ & $4.0 \mathrm{~g}-\mathrm{i}$ & $2.2 \mathrm{i}-\mathrm{k}$ & $2.9 \mathrm{ij}$ & 2.7hi & $1.9 \mathrm{j}-1$ & 1.51 & $1.4 \mathrm{i}-\mathrm{l}$ & $2.0 \mathrm{kl}$ \\
\hline & $\mathrm{C} 2$ & $8.0 \mathrm{f}$ & $4.9 \mathrm{ef}$ & $3.9 h-j$ & $4.1 \mathrm{fg}$ & 3.0hi & $2.3 \mathrm{~h}-\mathrm{j}$ & $2.9 \mathrm{gh}$ & 2.7hi \\
\hline & $\mathrm{C} 3$ & $19.0 \mathrm{c}$ & $10.9 \mathrm{c}$ & $13.8 \mathrm{~d}$ & $10.7 \mathrm{e}$ & $7.1 \mathrm{f}$ & $2.9 \mathrm{fg}$ & $5.6 \mathrm{e}$ & $3.3 \mathrm{e}-\mathrm{g}$ \\
\hline & $\mathrm{C} 4$ & $24.7 \mathrm{a}$ & $15.9 \mathrm{a}$ & $17.1 \mathrm{a}$ & $15.5 b$ & $12.0 \mathrm{c}$ & $4.6 \mathrm{~b}$ & $9.6 \mathrm{~cd}$ & $5.4 \mathrm{~b}^{\circ}$ \\
\hline $\mathrm{b}$ & & $6.3^{* *}$ & $3.8^{* *}$ & $4.3^{* *}$ & $3.7^{* *}$ & $2.7^{*}$ & $0.9^{* *}$ & $2.1 *$ & $1.1^{* *}$ \\
\hline $\mathrm{r}$ & & $0.96^{* *}$ & $0.94 * *$ & $0.89^{* *}$ & $0.92^{* *}$ & $0.88^{*}$ & $0.97^{* *}$ & 0.89 * & $0.96^{* *}$ \\
\hline \multirow[t]{5}{*}{ C } & $\mathrm{CO}$ & $1.0 \mathrm{j}$ & $1.0 \mathrm{kl}$ & 0.51 & $0.8 \mathrm{j}$ & $1.5 \mathrm{k}-\mathrm{m}$ & $0.8 \mathrm{~m}$ & $1.3 \mathrm{j}-1$ & $0.7 \mathrm{~m}$ \\
\hline & $\mathrm{C} 1$ & $5.0 \mathrm{~g}$ & $3.4 \mathrm{~g}-\mathrm{i}$ & $3.5 \mathrm{~h}-\mathrm{j}$ & 3.6gh & $2.4 \mathrm{ij}$ & $1.9 \mathrm{j}-1$ & $2.3 \mathrm{~h}-\mathrm{j}$ & $2.0 \mathrm{kl}$ \\
\hline & $\mathrm{C} 2$ & $7.0 \mathrm{f}$ & $4.5 \mathrm{fg}$ & $4.7 \mathrm{gh}$ & $3.5 \mathrm{gh}$ & $4.4 \mathrm{~g}$ & $2.5 \mathrm{~g}-\mathrm{i}$ & $4.2 \mathrm{f}$ & $2.4 \mathrm{~h}-\mathrm{k}$ \\
\hline & $\mathrm{C} 3$ & $16.2 \mathrm{~d}$ & $9.5 \mathrm{~d}$ & $12.1 \mathrm{e}$ & $11.9 \mathrm{~d}$ & $10.9 \mathrm{~d}$ & $3.1 \mathrm{ef}$ & $9.6 \mathrm{~cd}$ & $2.9 \mathrm{gh}$ \\
\hline & $\mathrm{C} 4$ & $24.2 \mathrm{ab}$ & $15.6 a$ & $15.9 \mathrm{ab}$ & $13.8 \mathrm{c}$ & $13.3 b$ & $3.9 \mathrm{~cd}$ & $10.7 \mathrm{bc}$ & 3.8de \\
\hline $\mathrm{b}$ & & $5.8^{* *}$ & $3.5^{* *}$ & $3.9 * *$ & $3.4^{*}$ & 3.2 * & $0.7^{* *}$ & $2.6^{* *}$ & $0.7^{* *}$ \\
\hline $\mathrm{r}$ & & $0.94 * *$ & $0.92 * *$ & $0.94^{* *}$ & 0.89 * & $0.92 *$ & $0.99 * *$ & $0.93 * *$ & $0.96^{* *}$ \\
\hline \multirow[t]{5}{*}{$\mathrm{D}$} & $\mathrm{CO}$ & $0.7 j$ & $1.5 \mathrm{kl}$ & 0.91 & $1.2 \mathrm{j}$ & $1.0 \mathrm{~m}$ & $0.8 \mathrm{~m}$ & 0.81 & $0.8 \mathrm{~m}$ \\
\hline & $\mathrm{C} 1$ & $4.9 \mathrm{gh}$ & $3.0 \mathrm{~h}-\mathrm{j}$ & $2.5 \mathrm{jk}$ & $3.1 \mathrm{~g}-\mathrm{i}$ & $1.41 \mathrm{~m}$ & $1.7 \mathrm{kl}$ & $1.1 \mathrm{j}-1$ & $1.9 \mathrm{kl}$ \\
\hline & $\mathrm{C} 2$ & $7.8 \mathrm{f}$ & $3.8 \mathrm{f}-\mathrm{h}$ & 4.2hi & $3.3 \mathrm{~g}-\mathrm{i}$ & $5.1 \mathrm{~g}$ & $2.2 \mathrm{i}-\mathrm{k}$ & $3.0 \mathrm{f}-\mathrm{h}$ & $3.2 \mathrm{fg}$ \\
\hline & $\mathrm{C} 3$ & $18.6 c$ & $12.2 \mathrm{~b}$ & $10.1 \mathrm{f}$ & $11.9 \mathrm{~d}$ & $12.8 \mathrm{bc}$ & $2.8 \mathrm{f}-\mathrm{h}$ & $10.9 b$ & $3.3 \mathrm{e}^{\circ}-\mathrm{g}$ \\
\hline & $\mathrm{C} 4$ & $24.3 \mathrm{a}$ & $15.3 \mathrm{a}$ & $15.6 \mathrm{bc}$ & $15.5 b$ & $16.0 \mathrm{a}$ & $4.6 \mathrm{~b}$ & $13.6 \mathrm{a}$ & $6.0 a^{\circ}$ \\
\hline $\mathrm{b}$ & & $6.1^{* *}$ & $3.7^{*}$ & $3.7^{* *}$ & $3.7^{*}$ & $4.4^{* *}$ & $0.8^{* *}$ & $3.5 *$ & $1.2 * *$ \\
\hline $\mathrm{r}$ & & $0.96^{* *}$ & $0.89^{*}$ & $0.92 * *$ & 0.88 * & $0.92 * *$ & $0.93^{* *}$ & 0.88 * & 0.92 ** \\
\hline
\end{tabular}


Table A4. Cont.

\begin{tabular}{|c|c|c|c|c|c|c|c|c|c|}
\hline \multirow[t]{2}{*}{ Population } & \multirow[t]{2}{*}{ Cycle } & \multicolumn{4}{|c|}{$\begin{array}{c}\text { TAY in Husk } \\
(\mathrm{kg} \mathrm{CGE/DW} \mathrm{ha-1)}\end{array}$} & \multicolumn{4}{|c|}{$\begin{array}{c}\text { TAY in Cob } \\
(\mathrm{kg} \mathrm{CGE/DW} \mathrm{ha-1)}\end{array}$} \\
\hline & & E1 & E2 & E3 & E4 & E1 & E2 & E3 & E4 \\
\hline \multirow[t]{5}{*}{ E } & $\mathrm{CO}$ & $1.1 \mathrm{j}$ & $1.2 \mathrm{kl}$ & 0.81 & $1.0 \mathrm{j}$ & $1.0 \mathrm{~m}$ & $0.8 \mathrm{~m}$ & $1.0 \mathrm{kl}$ & $0.9 \mathrm{~m}$ \\
\hline & $\mathrm{C} 1$ & 3.7hi & $3.1 \mathrm{~h}-\mathrm{j}$ & 3.0ij & $3.8 \mathrm{~g}$ & $2.3 \mathrm{i}-\mathrm{k}$ & $1.9 \mathrm{j}-1$ & $2.2 \mathrm{~h}-\mathrm{k}$ & $2.2 \mathrm{j}-1$ \\
\hline & $\mathrm{C} 2$ & $9.5 \mathrm{e}$ & $6.1 \mathrm{e}$ & $6.0 \mathrm{~g}$ & $5.0 \mathrm{f}$ & $3.5 \mathrm{~h}$ & $2.2 \mathrm{i}-\mathrm{k}$ & $2.6 \mathrm{hi}$ & $2.5 \mathrm{~h}-\mathrm{j}$ \\
\hline & $\mathrm{C} 3$ & $18.5 c$ & $12.1 \mathrm{bc}$ & $15.8 \mathrm{ab}$ & $13.8 \mathrm{c}$ & $9.9 \mathrm{e}$ & $3.2 \mathrm{ef}$ & $8.7 \mathrm{~d}$ & 3.6ef \\
\hline & $\mathrm{C} 4$ & $22.9 \mathrm{~b}$ & $16.5 \mathrm{a}$ & $16.9 \mathrm{ab}$ & $18.2 \mathrm{a}$ & $12.1 \mathrm{c}$ & $5.5 a$ & $10.5 \mathrm{bc}$ & $4.7 \mathrm{c}$ \\
\hline $\mathrm{b}$ & & $5.9^{* *}$ & $4.0^{* *}$ & $4.5^{* *}$ & $4.6^{* *}$ & $3.0 *$ & $1.1^{*}$ & $2.6^{*}$ & $0.9^{* *}$ \\
\hline $\mathrm{r}$ & & $0.97^{* *}$ & $0.96^{* *}$ & 0.92 ** & $0.93^{* *}$ & $0.91 *$ & 0.91 * & $0.88^{*}$ & $0.98^{* *}$ \\
\hline \multirow{3}{*}{ Check var. } & KND & 3.0 & 0.9 & 1.6 & 1.1 & 6.2 & 3.6 & 6.2 & 3.5 \\
\hline & KGW & 2.6 & 0.7 & 1.5 & 0.6 & 3.4 & 0.6 & 2.5 & 1.4 \\
\hline & P339 & 0.2 & 0.0 & 0.1 & 0.0 & 0.0 & 0.1 & 0.0 & 0.0 \\
\hline
\end{tabular}

* and ${ }^{* *}$ significant at 0.05 and 0.01 probability levels; ${ }^{1}$ means in a column followed by the same letter are not significantly different at 0.05 probability levels; $b$ - response to selection; $r$-correlation coefficient; DAP—days after planting; E1-Khon Kaen, dry season; E2-Khon Kaen, rainy season; E3-Uthai Thani, dry season; E4-Uthai Thani, rainy season.

Table A5. Means for total anthocyanin content (TAC), total phenolic content (TPC) of (A-E) five populations and $(\mathrm{C} 0-\mathrm{C} 4)$ five cycles in husk evaluated in four environments.

\begin{tabular}{|c|c|c|c|c|c|c|c|c|c|}
\hline \multirow[t]{2}{*}{ Population } & \multirow[t]{2}{*}{ Cycle } & \multicolumn{4}{|c|}{$\begin{array}{c}\text { TAC } \\
\text { (mg CGE/g } 100 \mathrm{DW})\end{array}$} & \multicolumn{4}{|c|}{$\begin{array}{c}\text { TPC } \\
\text { (mg GAE/100 g DW) }\end{array}$} \\
\hline & & E1 & E2 & E3 & E4 & E1 & E2 & E3 & E4 \\
\hline \multirow[t]{5}{*}{ A } & $\mathrm{CO}$ & $102.7 n^{1}$ & $93.8 n$ & 163.60 & 134.3no & $188.3 n$ & $147.2 n$ & $197.2 q$ & 183.1rs \\
\hline & $\mathrm{C} 1$ & $275.5 \mathrm{~m}$ & 288.51 & $342.8 \mathrm{mn}$ & $326.9 \mathrm{~m}$ & 362.21 & $562.7 \mathrm{jk}$ & 381.50 & $631.0 \mathrm{kl}$ \\
\hline & $\mathrm{C} 2$ & $730.6 \mathrm{i}$ & $685.1 \mathrm{~h}$ & $609.0 \mathrm{i}$ & $549.8 \mathrm{i}$ & $975.1 \mathrm{~h}$ & $949.2 \mathrm{~g}$ & $822.6 j$ & $839.9 \mathrm{i}$ \\
\hline & C3 & $1672.5 f$ & $1657.4 d$ & $1586.7 \mathrm{e}$ & $1489.2 f$ & 1927.2ef & $1890.1 d$ & 1779.7gh & 1651.2gh \\
\hline & $\mathrm{C} 4$ & $2251.8 \mathrm{a}$ & $2029.5 \mathrm{ab}$ & $1953.6 a$ & $1704.1 d$ & $2685.4 a$ & $2253.4 \mathrm{c}$ & $2472.6 a$ & $1937.7 d$ \\
\hline $\mathrm{b}$ & & $569.5^{* *}$ & $524.0 * *$ & $482.4^{* *}$ & $430.2 * *$ & $655.9^{* *}$ & $554.0 * *$ & $594.9^{* *}$ & $452.9^{* *}$ \\
\hline $\mathrm{r}$ & & $0.95 * *$ & $0.94 * *$ & $0.93^{* *}$ & $0.92^{* *}$ & $0.95^{* *}$ & $0.97^{* *}$ & $0.94^{* *}$ & $0.97^{* *}$ \\
\hline \multirow[t]{5}{*}{ B } & $\mathrm{CO}$ & $56.4 \mathrm{o}$ & $137.6 \mathrm{mn}$ & $117.6 \mathrm{p}$ & 126.1no & 129.90 & $308.1 \mathrm{~m}$ & $177.2 q$ & $225.1 \mathrm{qr}$ \\
\hline & $\mathrm{C} 1$ & 357.31 & 289.91 & $348.6 \mathrm{~m}$ & $291.8 \mathrm{~m}$ & $564.1 \mathrm{j}$ & 478.71 & $477.4 n$ & 365.20 \\
\hline & $\mathrm{C} 2$ & 744.6hi & $614.8 \mathrm{i}$ & $511.8 \mathrm{k}$ & $534.6 \mathrm{ij}$ & 988.1h & $523.2 \mathrm{j}-1$ & 632.91 & $446.5 n$ \\
\hline & $\mathrm{C} 3$ & $1708.5 \mathrm{e}$ & $1547.8 \mathrm{e}$ & $1531.9 f$ & $1397.6 \mathrm{~g}$ & $1949.8 \mathrm{e}$ & $1684.6 \mathrm{e}$ & $1887.6 \mathrm{f}$ & $1601.8 \mathrm{~h}$ \\
\hline & $\mathrm{C} 4$ & $2244.3 a$ & $2001.9 b c$ & $1924.7 b$ & $1895.0 \mathrm{c}$ & $2510.7 \mathrm{~b}$ & $2204.7 c$ & $2177.3 d$ & $2100.1 c$ \\
\hline $\mathrm{b}$ & & $572.7 * *$ & $498.7^{* *}$ & $479.8^{* *}$ & $464.7 * *$ & $614.7^{* *}$ & $499.9 *$ & 541.0 * & $498.7 *$ \\
\hline $\mathrm{r}$ & & $0.96^{* *}$ & $0.93 * *$ & $0.92 * *$ & $0.93^{* *}$ & $0.98^{* *}$ & $0.86^{*}$ & $0.91 *$ & $0.87^{*}$ \\
\hline \multirow[t]{5}{*}{$C$} & $\mathrm{C} 0$ & $118.6 n$ & $127.1 \mathrm{mn}$ & $64.1 \mathrm{q}$ & 99.1o & $297.6 \mathrm{~m}$ & $250.4 \mathrm{~m}$ & $155.9 q$ & $146.2 \mathrm{~s}$ \\
\hline & $\mathrm{C} 1$ & $523.9 \mathrm{j}$ & $425.0 \mathrm{k}$ & 395.81 & 421.61 & $654.1 \mathrm{i}$ & $784.0 \mathrm{~h}$ & $537.2 \mathrm{~m}$ & $727.1 \mathrm{j}$ \\
\hline & $\mathrm{C} 2$ & $762.8 \mathrm{~h}$ & $532.9 \mathrm{j}$ & $575.6 \mathrm{j}$ & $462.9 \mathrm{kl}$ & 998.4gh & $676.9 \mathrm{i}$ & $746.2 \mathrm{k}$ & $579.71 \mathrm{~m}$ \\
\hline & $\mathrm{C} 3$ & $1699.1 \mathrm{e}$ & $1397.5 \mathrm{f}$ & $1450.9 \mathrm{~g}$ & $1543.8 \mathrm{e}$ & $2039.4 d$ & $1553.3 f$ & 1741.7h & 1706.1f \\
\hline & $\mathrm{C} 4$ & $2156.7 \mathrm{~b}$ & $1993.2 b c$ & $1879.6 \mathrm{c}$ & $1858.7 \mathrm{c}$ & $2426.0 \mathrm{c}$ & $2413.8 \mathrm{a}$ & $2292.3 c$ & $2237.7 b$ \\
\hline $\mathrm{b}$ & & $525.1^{* *}$ & $470.5^{* *}$ & $468.6^{* *}$ & $464.1 *$ & $564.2^{* *}$ & $509.6 *$ & $547.7^{* *}$ & $516.2 *$ \\
\hline $\mathrm{r}$ & & $0.96^{* *}$ & $0.92 * *$ & $0.95^{* *}$ & $0.90 *$ & $0.96^{* *}$ & $0.89^{*}$ & $0.95^{* *}$ & $0.89^{*}$ \\
\hline \multirow[t]{5}{*}{$\mathrm{D}$} & $\mathrm{CO}$ & $71.3 \mathrm{o}$ & $185.8 \mathrm{~m}$ & $151.5 \mathrm{o}$ & $170.5 n$ & 158.0no & $316.1 \mathrm{~m}$ & $267.7 p$ & $298.4 p$ \\
\hline & $\mathrm{C} 1$ & $452.1 \mathrm{k}$ & $377.2 \mathrm{k}$ & $322.1 \mathrm{n}$ & 426.01 & $694.1 \mathrm{i}$ & $492.5 \mathrm{kl}$ & 389.40 & $640.7 \mathrm{k}$ \\
\hline & $\mathrm{C} 2$ & 753.1hi & $509.1 \mathrm{j}$ & $613.6 \mathrm{i}$ & $461.7 \mathrm{kl}$ & $994.3 \mathrm{~h}$ & $579.2 j$ & $834.1 \mathrm{j}$ & $539.7 \mathrm{~m}$ \\
\hline & $\mathrm{C} 3$ & $1716.6 \mathrm{e}$ & $1504.9 \mathrm{e}$ & $1572.3 e$ & $1559.7 \mathrm{e}$ & $2046.3 d$ & $1655.1 \mathrm{e}$ & $1809.0 \mathrm{~g}$ & $1661.3 \mathrm{fg}$ \\
\hline & $\mathrm{C} 4$ & $2031.4 d$ & 1957.1c & $1841.0 \mathrm{~d}$ & $1949.4 b$ & $2418.7 \mathrm{c}$ & $2337.0 \mathrm{ab}$ & $2116.1 \mathrm{e}$ & $2193.4 b$ \\
\hline $\mathrm{b}$ & & $518.5^{* *}$ & 467.0 * & $462.9^{* *}$ & $469.2^{*}$ & $587.7^{* *}$ & $520.4 *$ & $511.6^{* *}$ & $481.1^{*}$ \\
\hline $\mathrm{r}$ & & $0.96^{* *}$ & $0.90 *$ & $0.93^{* *}$ & $0.89^{*}$ & $0.97^{* *}$ & $0.88^{*}$ & $0.93^{* *}$ & 0.87 * \\
\hline \multirow[t]{5}{*}{$E$} & $\mathrm{CO}$ & $104.6 n$ & $159.7 \mathrm{mn}$ & $99.1 \mathrm{p}$ & 120.4 no & 396.21 & $291.2 \mathrm{~m}$ & $169.7 q$ & $254.6 \mathrm{pq}$ \\
\hline & $\mathrm{C} 1$ & 351.51 & $428.6 \mathrm{k}$ & $360.5 \mathrm{~m}$ & 485.7jk & $467.3 \mathrm{k}$ & $668.7 \mathrm{i}$ & $478.8 n$ & $745.8 \mathrm{j}$ \\
\hline & $\mathrm{C} 2$ & $850.5 \mathrm{~g}$ & $798.9 \mathrm{~g}$ & $675.7 \mathrm{~h}$ & $683.4 \mathrm{~h}$ & $1043.8 \mathrm{~g}$ & $953.5 \mathrm{~g}$ & $1003.7 \mathrm{i}$ & $889.9 \mathrm{i}$ \\
\hline & $\mathrm{C} 3$ & $1660.3 \mathrm{f}$ & $1535.9 \mathrm{e}$ & $1523.5 f$ & $1680.4 \mathrm{~d}$ & 1899.3f & $1656.3 \mathrm{e}$ & $1760.1 \mathrm{~h}$ & $1882.0 \mathrm{e}$ \\
\hline & $\mathrm{C} 4$ & $2085.2 c$ & $2077.4 \mathrm{a}$ & $1942.8 \mathrm{ab}$ & $2249.3 a$ & $2415.3 c$ & $2263.9 b c$ & $2399.6 b$ & $2407.6 a$ \\
\hline $\mathrm{b}$ & & $527.0^{* *}$ & $494.3^{* *}$ & $485.0 * *$ & $545.3^{* *}$ & $547.0^{* *}$ & $493.3 * *$ & $574.1^{* *}$ & $544.2 * *$ \\
\hline $\mathrm{r}$ & & $0.97^{* *}$ & $0.97^{* *}$ & $0.96^{* *}$ & $0.94^{* *}$ & $0.95^{* *}$ & $0.97^{* *}$ & $0.98^{* *}$ & $0.95^{* *}$ \\
\hline \multirow{3}{*}{ Check var. } & KND & 270.3 & 132.7 & 229.6 & 138.5 & 534.2 & 185.1 & 439.2 & 185.1 \\
\hline & KGW & 238.7 & 128.9 & 234.0 & 109.6 & 446.2 & 172.3 & 462.4 & 173.7 \\
\hline & P339 & 11.0 & 1.2 & 10.8 & 1.2 & 44.7 & 22.5 & 44.4 & 28.1 \\
\hline
\end{tabular}

* and ** significant at 0.05 and 0.01 probability levels; ${ }^{1}$ means in a column followed by the same letter are not significantly different at 0.05 probability levels; $\mathrm{b}$-response to selection; $\mathrm{r}$-correlation coefficient; E1-Khon Kaen, dry season; E2-Khon Kaen, rainy season; E3-Uthai Thani, dry season; E4-Uthai Thani, rainy season. 
Table A6. Means for antioxidant activity determined by the DPPH and the TEAC methods of (A-E) five populations and $(\mathrm{C} 0-\mathrm{C} 4)$ five cycles in husk evaluated in four environments.

\begin{tabular}{|c|c|c|c|c|c|c|c|c|c|}
\hline \multirow[t]{2}{*}{ Population } & \multirow[t]{2}{*}{ Cycle } & \multicolumn{4}{|c|}{$\begin{array}{c}\text { DPPH } \\
(\mathrm{mmol} \text { TE/100 g DW) }\end{array}$} & \multicolumn{4}{|c|}{$\begin{array}{c}\text { TEAC } \\
(\mathrm{mmol} \text { TE/100 } \mathrm{g} \mathrm{DW})\end{array}$} \\
\hline & & E1 & E2 & E3 & E4 & E1 & E2 & E3 & E4 \\
\hline \multirow[t]{5}{*}{$\mathrm{A}$} & $\mathrm{CO}$ & $27.3 \mathrm{~s}^{1}$ & $34.1 \mathrm{p}$ & $33.81 \mathrm{~m}$ & $55.7 \mathrm{mn}$ & $169.0 \mathrm{p}$ & $117.8 \mathrm{p}$ & 294.90 & $102.1 \mathrm{~m}$ \\
\hline & $\mathrm{C} 1$ & $61.4 p$ & 110.01 & $46.5 \mathrm{j}$ & $161.4 \mathrm{~h}$ & 526.61 & 168.9no & 449.01 & $193.2 \mathrm{k}$ \\
\hline & $\mathrm{C} 2$ & 96.21 & $169.4 \mathrm{~g}$ & $99.2 \mathrm{f}$ & $153.7 \mathrm{i}$ & $743.2 \mathrm{j}$ & $353.6 \mathrm{k}$ & $789.3 \mathrm{~h}$ & $332.6 \mathrm{i}$ \\
\hline & $\mathrm{C} 3$ & $250.9 \mathrm{e}$ & $383.1 \mathrm{c}$ & $243.5 c$ & $351.0 \mathrm{~g}$ & $1651.1 \mathrm{e}$ & $972.5 \mathrm{i}$ & $1468.6 \mathrm{~g}$ & $974.8 \mathrm{~g}$ \\
\hline & $\mathrm{C} 4$ & 298.0a & $423.1 b$ & $265.2 b$ & $392.4 d$ & $2218.4 a$ & $1789.1 d$ & $1980.6 b$ & $1584.4 \mathrm{~d}$ \\
\hline $\mathrm{b}$ & & $73.1^{* *}$ & $105.1^{* *}$ & $66.0 *$ & $86.3 *$ & $522.3^{* *}$ & $414.6^{*}$ & $439.1^{* *}$ & 374.6 * \\
\hline $\mathrm{r}$ & & $0.92 * *$ & $0.94^{* *}$ & $0.91 *$ & $0.91 *$ & $0.95^{* *}$ & $0.86^{*}$ & $0.95^{* *}$ & $0.88^{*}$ \\
\hline \multirow[t]{5}{*}{ B } & $\mathrm{CO}$ & $22.1 \mathrm{t}$ & $51.8 \mathrm{o}$ & $37.4 \mathrm{kl}$ & 49.6no & $136.1 \mathrm{p}$ & $106.9 p$ & 269.0op & $155.7 \mathrm{kl}$ \\
\hline & $\mathrm{C} 1$ & 67.50 & $153.4 \mathrm{~h}$ & $42.6 \mathrm{jk}$ & $130.9 \mathrm{k}$ & $489.4 \mathrm{~m}$ & $223.7 \mathrm{~m}$ & $338.5 n$ & $160.4 \mathrm{kl}$ \\
\hline & $\mathrm{C} 2$ & $105.1 \mathrm{k}$ & $130.3 \mathrm{k}$ & $84.3 \mathrm{~h}$ & $145.6 \mathrm{j}$ & $885.5 \mathrm{~h}$ & $319.8 \mathrm{kl}$ & $748.4 \mathrm{i}$ & $269.3 j$ \\
\hline & $\mathrm{C} 3$ & $228.3 \mathrm{~h}$ & $327.6 \mathrm{f}$ & $224.7 \mathrm{~d}$ & $357.0 \mathrm{fg}$ & $1573.4 \mathrm{f}$ & 1044.9h & $1461.5 \mathrm{~g}$ & $1013.0 \mathrm{fg}$ \\
\hline & $\mathrm{C} 4$ & $294.1 \mathrm{ab}$ & $363.7 \mathrm{~d}$ & $239.3 c$ & $403.0 c$ & $2081.4 b$ & $1732.5 \mathrm{e}$ & $1777.7 \mathrm{~cd}$ & $1713.9 c$ \\
\hline $\mathrm{b}$ & & $70.5^{* *}$ & $79.8 *$ & $58.6 *$ & $93.3^{*}$ & $497.5^{* *}$ & $407.2 *$ & $414.0^{* *}$ & $396.9 *$ \\
\hline $\mathrm{r}$ & & $0.96^{* *}$ & $0.89 *$ & 0.88 * & 0.92 * & $0.98^{* *}$ & $0.87^{*}$ & $0.94^{* *}$ & $0.83 *$ \\
\hline \multirow[t]{5}{*}{$\mathrm{C}$} & $\mathrm{CO}$ & $33.7 \mathrm{r}$ & $46.3 \mathrm{o}$ & $18.2 n$ & 45.10 & $265.9 \mathrm{o}$ & 151.1op & $134.2 q$ & $138.01 \mathrm{~m}$ \\
\hline & $\mathrm{C} 1$ & $74.6 n$ & 149.8hi & $49.8 \mathrm{ij}$ & 122.01 & $612.3 \mathrm{k}$ & $228.5 \mathrm{~m}$ & 446.61 & $248.5 j$ \\
\hline & $\mathrm{C} 2$ & $117.7 \mathrm{i}$ & $143.8 \mathrm{ij}$ & $88.0 \mathrm{gh}$ & $145.0 \mathrm{j}$ & $834.1 \mathrm{i}$ & $361.7 \mathrm{k}$ & $601.3 \mathrm{j}$ & $278.4 j$ \\
\hline & $\mathrm{C} 3$ & $229.8 \mathrm{~h}$ & $329.1 \mathrm{f}$ & $213.5 \mathrm{e}$ & $352.3 \mathrm{~g}$ & $1640.6 \mathrm{e}$ & $954.9 \mathrm{i}$ & $1619.6 \mathrm{ef}$ & $1010.1 \mathrm{fg}$ \\
\hline & $\mathrm{C} 4$ & $285.8 c$ & $453.7 \mathrm{a}$ & $263.1 b$ & $403.2 \mathrm{c}$ & $1967.2 \mathrm{c}$ & $1890.1 c$ & $1807.2 \mathrm{c}$ & $1753.9 \mathrm{c}$ \\
\hline $\mathrm{b}$ & & $65.9^{* *}$ & $99.4^{* *}$ & $65.6^{* *}$ & $94.7^{* *}$ & $443.1^{* *}$ & $420.4 *$ & $451.9^{* *}$ & 399.3 * \\
\hline $\mathrm{r}$ & & $0.97^{* *}$ & $0.92 * *$ & $0.94^{* *}$ & $0.93^{* *}$ & $0.96^{* *}$ & $0.83 *$ & $0.92 *$ & $0.84^{*}$ \\
\hline \multirow[t]{5}{*}{$\mathrm{D}$} & $\mathrm{CO}$ & $25.6 \mathrm{st}$ & $48.5 \mathrm{o}$ & $30.91 \mathrm{~m}$ & $56.9 \mathrm{~m}$ & $160.7 p$ & $115.9 p$ & $240.2 p$ & $151.6 \mathrm{kl}$ \\
\hline & $\mathrm{C} 1$ & $81.2 \mathrm{~m}$ & $100.4 \mathrm{~m}$ & $46.9 \mathrm{ij}$ & $153.2 \mathrm{i}$ & $506.11 \mathrm{~m}$ & $202.8 \mathrm{mn}$ & $376.6 \mathrm{~m}$ & $266.6 \mathrm{j}$ \\
\hline & $\mathrm{C} 2$ & $110.1 \mathrm{j}$ & $143.2 \mathrm{ij}$ & $92.7 \mathrm{fg}$ & 120.41 & 816.0i & 288.81 & $728.4 \mathrm{i}$ & $289.8 \mathrm{ij}$ \\
\hline & $\mathrm{C} 3$ & $235.4 \mathrm{~g}$ & $350.0 \mathrm{e}$ & 219.0de & $382.5 \mathrm{e}$ & $1720.9 \mathrm{~d}$ & $1141.5 \mathrm{~g}$ & 1641.1e & 1047.3f \\
\hline & $\mathrm{C} 4$ & $289.6 \mathrm{bc}$ & $427.2 b$ & $237.8 \mathrm{c}$ & $423.3 b$ & 1997.7c & $2127.2 \mathrm{a}$ & $1758.7 \mathrm{~d}$ & $1946.3 b$ \\
\hline$b$ & & $68.2^{* *}$ & $100.7^{* *}$ & $58.6 *$ & $96.2 *$ & $488.9^{* *}$ & 496.1 * & 430.2 * & 437.0 * \\
\hline $\mathrm{r}$ & & $0.96^{* *}$ & $0.93 * *$ & 0.91 * & 0.85 * & $0.96^{* *}$ & $0.83 *$ & $0.92 *$ & $0.82 *$ \\
\hline \multirow[t]{5}{*}{$\mathrm{E}$} & $\mathrm{CO}$ & $38.6 q$ & $62.9 n$ & $29.2 \mathrm{~m}$ & $61.8 \mathrm{~m}$ & $350.2 n$ & 130.2op & $79.0 \mathrm{r}$ & $129.7 \mathrm{~lm}$ \\
\hline & $\mathrm{C} 1$ & $62.3 p$ & $135.5 \mathrm{jk}$ & $53.9 \mathrm{i}$ & 122.91 & $581.8 \mathrm{k}$ & $202.3 \mathrm{mn}$ & $486.6 \mathrm{k}$ & 295.6ij \\
\hline & $\mathrm{C} 2$ & $120.9 \mathrm{i}$ & $171.1 \mathrm{~g}$ & $99.2 \mathrm{f}$ & $131.3 \mathrm{k}$ & $980.8 \mathrm{~g}$ & $422.3 \mathrm{j}$ & $807.4 \mathrm{~h}$ & $382.2 \mathrm{~h}$ \\
\hline & $\mathrm{C} 3$ & $240.8 \mathrm{f}$ & 367.6d & $216.2 \mathrm{e}$ & $360.4 f$ & $1673.9 \mathrm{e}$ & 1370.1f & $1592.9 f$ & 1321.1e \\
\hline & $\mathrm{C} 4$ & $278.9 \mathrm{~d}$ & $451.4 \mathrm{a}$ & $274.1 \mathrm{a}$ & $444.9 \mathrm{a}$ & $2218.2 a$ & $2060.6 b$ & $2037.7 \mathrm{a}$ & $2044.4 a$ \\
\hline $\mathrm{b}$ & & $65.9 * *$ & $100.9^{* *}$ & $65.2^{* *}$ & 100.4 * & $482.8^{* *}$ & $502.9^{*}$ & $502.4^{* *}$ & 485.5 * \\
\hline $\mathrm{r}$ & & $0.95^{* *}$ & $0.94^{* *}$ & $0.95^{* *}$ & $0.90^{*}$ & $0.97^{* *}$ & 0.89 * & $0.98^{* *}$ & $0.88^{*}$ \\
\hline \multirow{3}{*}{ Check var. } & KND & 60.5 & 44.8 & 46.8 & 48.3 & 353.9 & 120.0 & 323.8 & 118.8 \\
\hline & KGW & 49.3 & 46.8 & 46.2 & 43.2 & 298.6 & 118.0 & 302.0 & 104.3 \\
\hline & P339 & 12.8 & 15.6 & 12.8 & 17.9 & 33.5 & 47.7 & 36.2 & 46.2 \\
\hline
\end{tabular}

* and ** significant at 0.05 and 0.01 probability levels; ${ }^{1}$ means in a column followed by the same letter are not significantly different at 0.05 probability levels; $b$-response to selection; $r$-correlation coefficient; E1-Khon Kaen, dry season; E2-Khon Kaen, rainy season; E3-Uthai Thani, dry season; E4-Uthai Thani, rainy season.

Table A7. Means for total anthocyanin content (TAC), total phenolic content (TPC) of (A-E) five populations and $(\mathrm{C} 0-\mathrm{C} 4)$ five cycles in cob evaluated in four environments.

\begin{tabular}{|c|c|c|c|c|c|c|c|c|c|}
\hline \multirow[t]{2}{*}{ Population } & \multirow[t]{2}{*}{ Cycle } & \multicolumn{4}{|c|}{$\begin{array}{c}\text { TAC } \\
(\mathrm{mg} \mathrm{CGE} / \mathrm{g} 100 \mathrm{DW})\end{array}$} & \multicolumn{4}{|c|}{$\begin{array}{c}\text { TPC } \\
(\mathrm{mg} \mathrm{GAE} / 100 \mathrm{~g} \text { DW) }\end{array}$} \\
\hline & & E1 & E2 & E3 & E4 & E1 & E2 & E3 & E4 \\
\hline \multirow[t]{5}{*}{$\mathrm{A}$} & $\mathrm{CO}$ & $143.8 \mathrm{op}^{1}$ & 59.21 & $130.9 \mathrm{~m}-\mathrm{o}$ & 52.60 & $322.7 \mathrm{mn}$ & $184.7 \mathrm{p}$ & $307.9 \mathrm{mn}$ & $208.7 n$ \\
\hline & $\mathrm{C} 1$ & $197.4 \mathrm{mn}$ & $184.8 \mathrm{j}$ & $187.0 \mathrm{kl}$ & $217.4 \mathrm{~m}$ & $351.01 \mathrm{~m}$ & 579.41 & 286.3no & $523.9 \mathrm{k}$ \\
\hline & $\mathrm{C} 2$ & $432.9 \mathrm{i}$ & $276.5 \mathrm{~h}$ & $431.5 \mathrm{~g}$ & $279.5 \mathrm{k}$ & 696.1hi & $785.5 \mathrm{~h}$ & $752.4 \mathrm{~h}$ & $623.5 \mathrm{ij}$ \\
\hline & $\mathrm{C} 3$ & $577.8 \mathrm{~g}$ & $416.4 \mathrm{e}$ & $635.2 \mathrm{f}$ & 387.5hi & $1188.8 \mathrm{f}$ & $858.9 \mathrm{~g}$ & $1184.2 \mathrm{~g}$ & $777.9 \mathrm{gh}$ \\
\hline & $\mathrm{C} 4$ & $1137.5 \mathrm{c}$ & 487.1c & $1167.4 \mathrm{~b}$ & $515.1 d$ & $1504.9 \mathrm{e}$ & $1603.1 \mathrm{a}$ & $1492.3 \mathrm{~d}$ & $1776.7 \mathrm{a}$ \\
\hline $\mathrm{b}$ & & $236.8^{*}$ & 108.7 * & $252.1^{* *}$ & $109.5^{* *}$ & $320.2 * *$ & $311.6^{*}$ & $326.7^{* *}$ & 339.0 ** \\
\hline $\mathrm{r}$ & & $0.88^{*}$ & $0.99 *$ & $0.91^{* *}$ & $0.98^{* *}$ & $0.94^{* *}$ & $0.90 *$ & $0.94 * *$ & $0.82 * *$ \\
\hline \multirow[t]{5}{*}{ B } & $\mathrm{CO}$ & 130.6op & 62.11 & $122.5 n-p$ & $57.1 \mathrm{o}$ & 260.8 op & 272.20 & 248.1op & $268.2 \mathrm{~m}$ \\
\hline & $\mathrm{C} 1$ & $169.3 \mathrm{no}$ & $176.1 \mathrm{j}$ & $156.91 \mathrm{~m}$ & $220.1 \mathrm{~m}$ & 384.31 & $627.4 \mathrm{k}$ & $355.31 \mathrm{~m}$ & $651.2 \mathrm{i}$ \\
\hline & $\mathrm{C} 2$ & $278.0 \mathrm{k}$ & $308.4 \mathrm{~g}$ & $345.4 \mathrm{~h}$ & $316.6 \mathrm{j}$ & $568.6 \mathrm{j}$ & $533.9 \mathrm{~m}$ & $550.2 j$ & $721.8 \mathrm{~h}$ \\
\hline & $\mathrm{C} 3$ & $643.2 \mathrm{f}$ & $370.0 \mathrm{f}$ & $629.0 \mathrm{f}$ & $418.0 \mathrm{fg}$ & $1234.1 \mathrm{f}$ & $660.1 \mathrm{jk}$ & $1193.8 \mathrm{~g}$ & $860.2 f$ \\
\hline & $\mathrm{C} 4$ & $1065.4 d$ & $576.1 \mathrm{~b}$ & $987.9 \mathrm{~d}$ & $595.0 \mathrm{~b}$ & 1508.4de & $1168.5 \mathrm{~d}$ & $1337.2 \mathrm{e}$ & $1045.1 d$ \\
\hline $\mathrm{b}$ & & 234.4 * & $122.2^{* *}$ & $220.3^{* *}$ & $127.4^{* *}$ & $334.5^{* *}$ & $182.5^{*}$ & $301.7^{* *}$ & $176.3^{* *}$ \\
\hline $\mathrm{r}$ & & $0.88 *$ & $0.97^{* *}$ & $0.92^{* *}$ & $0.99^{* *}$ & $0.93^{* *}$ & $0.78^{*}$ & $0.93^{* *}$ & $0.93^{* *}$ \\
\hline
\end{tabular}


Table A7. Cont.

\begin{tabular}{|c|c|c|c|c|c|c|c|c|c|}
\hline \multirow[t]{2}{*}{ Population } & \multirow[t]{2}{*}{ Cycle } & \multicolumn{4}{|c|}{$\begin{array}{c}\text { TAC } \\
(\mathrm{mg} \mathrm{CGE} / \mathrm{g} 100 \mathrm{DW})\end{array}$} & \multicolumn{4}{|c|}{$\begin{array}{c}\text { TPC } \\
(\mathrm{mg} \mathrm{GAE} / 100 \mathrm{~g} \mathrm{DW})\end{array}$} \\
\hline & & E1 & E2 & E3 & E4 & E1 & E2 & E3 & E4 \\
\hline \multirow[t]{5}{*}{$\mathrm{C}$} & $\mathrm{C} 0$ & 162.6no & $86.1 \mathrm{k}$ & $142.8 \mathrm{mn}$ & $84.3 n$ & 274.5no & $391.2 n$ & 208.2pq & 388.91 \\
\hline & $\mathrm{C} 1$ & 256.7kl & $228.6 \mathrm{i}$ & $247.6 j$ & $207.4 \mathrm{~m}$ & $575.9 j$ & $673.1 j$ & $580.3 \mathrm{j}$ & $557.1 \mathrm{k}$ \\
\hline & $\mathrm{C} 2$ & $420.4 \mathrm{i}$ & $308.2 \mathrm{~g}$ & $405.3 \mathrm{~g}$ & $292.1 \mathrm{k}$ & 720.3hi & $848.5 \mathrm{~g}$ & $684.4 \mathrm{i}$ & $656.3 \mathrm{i}$ \\
\hline & $\mathrm{C} 3$ & $1058.1 d$ & $376.3 \mathrm{f}$ & $1014.6 \mathrm{~d}$ & $327.6 \mathrm{j}$ & $1518.7 \mathrm{de}$ & 743.6hi & $1493.0 \mathrm{~d}$ & 754.2gh \\
\hline & $\mathrm{C} 4$ & $1208.3 b$ & $444.5 \mathrm{~d}$ & $1170.2 b$ & $485.6 \mathrm{e}$ & $1718.7 \mathrm{~b}$ & $985.8 \mathrm{e}$ & $1651.5 b$ & $1418.2 b$ \\
\hline $\mathrm{b}$ & & $289.3 *$ & $86.4^{* *}$ & $282.2 *$ & $92.3^{* *}$ & $383.1^{* *}$ & 126.0 * & $380.0^{* *}$ & 225.6 * \\
\hline $\mathrm{r}$ & & $0.91 *$ & $0.97^{* *}$ & $0.92 *$ & $0.96^{* *}$ & $0.94^{* *}$ & $0.80 *$ & $0.94 * *$ & $0.95 *$ \\
\hline \multirow[t]{5}{*}{$\mathrm{D}$} & $\mathrm{C} 0$ & $104.6 p$ & $93.7 \mathrm{k}$ & $96.4 p$ & $96.2 n$ & 211.7pq & $511.0 \mathrm{~m}$ & $196.1 q$ & $513.5 \mathrm{k}$ \\
\hline & $\mathrm{C} 1$ & 140.1op & $191.9 \mathrm{j}$ & $119.5 n-p$ & $225.41 \mathrm{~m}$ & $459.9 \mathrm{k}$ & $544.51 \mathrm{~m}$ & $424.8 \mathrm{k}$ & $569.6 \mathrm{jk}$ \\
\hline & $\mathrm{C} 2$ & $495.6 \mathrm{~h}$ & $262.6 \mathrm{~h}$ & 326.2hi & $369.2 \mathrm{i}$ & $742.1 \mathrm{~h}$ & $641.6 \mathrm{jk}$ & $395.5 \mathrm{kl}$ & 763.2gh \\
\hline & $\mathrm{C} 3$ & $1180.7 \mathrm{~b}$ & $362.3 \mathrm{f}$ & $1181.8 b$ & 405.4gh & $1629.3 \mathrm{c}$ & $738.5 \mathrm{i}$ & $1556.0 \mathrm{c}$ & $787.9 \mathrm{~g}$ \\
\hline & $\mathrm{C} 4$ & $1432.8 \mathrm{a}$ & $552.7 \mathrm{~b}$ & $1418.2 \mathrm{a}$ & 669.0a & $1949.5 a$ & $1549.0 \mathrm{~b}$ & $1953.4 \mathrm{a}$ & $1463.1 \mathrm{~b}$ \\
\hline $\mathrm{b}$ & & $369.7^{* *}$ & $108.8^{* *}$ & 370.6 * & $132.6^{* *}$ & $464.5^{* *}$ & 227.0ns & $464.6^{*}$ & 211.8 * \\
\hline $\mathrm{r}$ & & $0.93 * *$ & $0.96^{* *}$ & $0.88^{*}$ & $0.95 * *$ & $0.95^{* *}$ & $0.70 \mathrm{~ns}$ & $0.89 *$ & $0.78^{*}$ \\
\hline \multirow[t]{5}{*}{$\mathrm{E}$} & $\mathrm{C} 0$ & $104.6 p$ & $96.9 \mathrm{k}$ & 105.6op & $97.1 \mathrm{n}$ & $179.9 q$ & $401.5 n$ & $228.9 p q$ & 381.71 \\
\hline & $\mathrm{C} 1$ & $222.91 \mathrm{~m}$ & $229.4 \mathrm{i}$ & $207.6 \mathrm{k}$ & 238.91 & 398.41 & $624.5 \mathrm{k}$ & $329.4 \mathrm{mn}$ & $658.9 \mathrm{i}$ \\
\hline & $\mathrm{C} 2$ & $328.1 \mathrm{j}$ & $283.4 \mathrm{~h}$ & $301.3 \mathrm{i}$ & $276.0 \mathrm{k}$ & $661.1 \mathrm{i}$ & $921.8 \mathrm{f}$ & $547.9 \mathrm{j}$ & $550.3 \mathrm{k}$ \\
\hline & $\mathrm{C} 3$ & $963.9 \mathrm{e}$ & $412.3 \mathrm{e}$ & $930.8 \mathrm{e}$ & $434.8 \mathrm{f}$ & $1085.4 \mathrm{~g}$ & $865.9 \mathrm{~g}$ & $1282.8 \mathrm{f}$ & $946.5 \mathrm{e}$ \\
\hline & $\mathrm{C} 4$ & $1080.1 d$ & $636.4 a$ & $1059.8 \mathrm{c}$ & 549.1c & 1567.0d & $1483.5 \mathrm{c}$ & $1344.2 \mathrm{e}$ & $1308.5 \mathrm{c}$ \\
\hline b & & $269.2 *$ & $126.2^{* *}$ & $263.2 *$ & $110.0^{* *}$ & $346.1^{* *}$ & $240.5^{*}$ & 318.4 * & 214.1 * \\
\hline $\mathrm{r}$ & & $0.90 *$ & $0.95^{* *}$ & $0.89 *$ & $0.98 * *$ & $0.97^{* *}$ & $0.88^{*}$ & $0.90 *$ & $0.86^{*}$ \\
\hline \multirow{3}{*}{ Check var. } & KND & 542.5 & 416.9 & 580.7 & 437.5 & 1053.5 & 874.4 & 1081.4 & 941.3 \\
\hline & KGW & 307.3 & 81.0 & 284.9 & 161.6 & 563.4 & 269.6 & 467.2 & 462.9 \\
\hline & P339 & 3.1 & 6.5 & 1.9 & 2.8 & 83.5 & 85.3 & 76.2 & 106.8 \\
\hline
\end{tabular}

$\mathrm{ns},{ }^{*}$ and ${ }^{* *}$ not significant and significant at 0.05 and 0.01 probability levels, respectively; ${ }^{1}$ means in a column followed by the same letter are not significantly different at 0.05 probability levels; $b$-response to selection; $\mathrm{r}$-correlation coefficient; E1-Khon Kaen, dry season; E2—Khon Kaen, rainy season; E3-Uthai Thani, dry season; E4-Uthai Thani, rainy season.

Table A8. Means for antioxidant activity determined by the DPPH and the TEAC methods of (A-E) five populations and $(\mathrm{C} 0-\mathrm{C} 4)$ five cycles in cob evaluated in four environments.

\begin{tabular}{|c|c|c|c|c|c|c|c|c|c|}
\hline \multirow{3}{*}{ Population } & \multirow{3}{*}{ Cycle } & \multicolumn{4}{|c|}{ DPPH } & \multicolumn{4}{|c|}{ TEAC } \\
\hline & & \multicolumn{4}{|c|}{ (mmol TE/100 g DW) } & \multicolumn{4}{|c|}{ (mmol TE/100 g DW) } \\
\hline & & E1 & E2 & E3 & E4 & E1 & E2 & E3 & E4 \\
\hline \multirow[t]{5}{*}{ A } & $\mathrm{CO}$ & $38.2 n^{1}$ & $34.3 q$ & $37.91 \mathrm{~m}$ & $35.8 \mathrm{q}$ & $176.8 \mathrm{o}$ & $122.1 \mathrm{n}$ & $170.0 \mathrm{o}$ & 97.1o \\
\hline & $\mathrm{C} 1$ & $47.8 \mathrm{~m}$ & 50.7 no & $44.3 \mathrm{kl}$ & $68.0 \mathrm{~m}$ & 404.71 & $344.7 \mathrm{i}-\mathrm{k}$ & $372.3 \mathrm{~m}$ & $309.4 \mathrm{jk}$ \\
\hline & $\mathrm{C} 2$ & $97.3 \mathrm{i}$ & $90.6 \mathrm{k}$ & $92.2 \mathrm{i}$ & $86.6 \mathrm{k}$ & $772.2 \mathrm{gh}$ & 489.8gh & $699.6 \mathrm{~h}$ & $373.1 \mathrm{i}$ \\
\hline & $\mathrm{C} 3$ & $173.6 \mathrm{~g}$ & $144.6 \mathrm{f}$ & $166.8 \mathrm{de}$ & $143.9 \mathrm{~g}$ & $1218.7 \mathrm{f}$ & $795.8 \mathrm{e}$ & $1263.5 f$ & $760.1 \mathrm{f}$ \\
\hline & $\mathrm{C} 4$ & $205.2 d$ & $178.4 \mathrm{~b}$ & $197.5 c$ & $183.4 \mathrm{~b}$ & $1718.7 \mathrm{c}$ & $944.4 \mathrm{c}$ & $1613.0 \mathrm{c}$ & $1004.9 \mathrm{~b}$ \\
\hline $\mathrm{b}$ & & $46.0 * *$ & $38.2 * *$ & $44.2^{* *}$ & $37.1 * *$ & $389.8^{* *}$ & $209.6^{* *}$ & $377.7^{* *}$ & $266.6^{* *}$ \\
\hline $\mathrm{r}$ & & $0.95^{* *}$ & $0.98^{* *}$ & $0.94^{* *}$ & $0.97 * *$ & $0.98^{* *}$ & $0.99 * *$ & $0.98^{* *}$ & $0.96^{* *}$ \\
\hline \multirow[t]{5}{*}{ B } & $\mathrm{CO}$ & $30.0 \mathrm{o}$ & $41.9 p$ & $27.8 \mathrm{mn}$ & $35.7 q$ & $232.6 n$ & $154.5 \mathrm{mn}$ & $212.4 \mathrm{o}$ & 157.1n \\
\hline & $\mathrm{C} 1$ & $51.21 \mathrm{~m}$ & 52.1no & 42.41 & $67.7 \mathrm{~m}$ & 416.61 & $281.8 \mathrm{kl}$ & $391.8 \mathrm{~m}$ & $340.8 \mathrm{ij}$ \\
\hline & $\mathrm{C} 2$ & $84.2 \mathrm{j}$ & $99.0 \mathrm{j}$ & $107.9 \mathrm{~g}$ & $117.0 \mathrm{i}$ & $644.6 \mathrm{i}$ & $378.9 \mathrm{i}$ & $556.1 \mathrm{jk}$ & $431.2 \mathrm{~h}$ \\
\hline & $\mathrm{C} 3$ & $182.5 \mathrm{f}$ & $125.3 \mathrm{~h}$ & $150.8 \mathrm{f}$ & $170.7 \mathrm{~cd}$ & $1229.3 \mathrm{f}$ & $597.7 f$ & $1186.8 \mathrm{~g}$ & $892.9 \mathrm{~cd}$ \\
\hline & $\mathrm{C} 4$ & $208.3 \mathrm{~cd}$ & $207.0 \mathrm{a}$ & $191.5 c$ & $206.4 a$ & $1766.8 \mathrm{~b}$ & $1022.6 b$ & $1543.0 \mathrm{~d}$ & $921.5 c$ \\
\hline $\mathrm{b}$ & & $48.8^{* *}$ & $40.4^{* *}$ & $43.6^{* *}$ & $44.5^{* *}$ & $388.1^{* *}$ & $205.2 *$ & $345.6^{* *}$ & $208.1^{* *}$ \\
\hline $\mathrm{r}$ & & $0.94^{* *}$ & $0.92 * *$ & $0.98^{* *}$ & $0.99 * *$ & $0.94^{* *}$ & $0.91^{*}$ & $0.94^{* *}$ & $0.93 * *$ \\
\hline \multirow[t]{5}{*}{$\mathrm{C}$} & $\mathrm{CO}$ & $36.5 n$ & 48.1op & $24.1 n$ & $44.9 p$ & $285.0 \mathrm{~m}$ & $196.9 \mathrm{~m}$ & 199.50 & $185.9 \mathrm{mn}$ \\
\hline & $\mathrm{C} 1$ & $59.3 \mathrm{k}$ & $65.7 \mathrm{~m}$ & $54.6 \mathrm{k}$ & $57.0 \mathrm{n}$ & $534.7 \mathrm{j}$ & $374.2 \mathrm{ij}$ & $531.3 \mathrm{k}$ & 339.0ij \\
\hline & $\mathrm{C} 2$ & $98.2 \mathrm{i}$ & $132.7 \mathrm{~g}$ & 94.1hi & $97.2 \mathrm{j}$ & $755.0 \mathrm{~h}$ & $573.1 \mathrm{f}$ & $726.7 \mathrm{~h}$ & $493.1 \mathrm{~g}$ \\
\hline & $\mathrm{C} 3$ & $193.1 \mathrm{e}$ & 149.1ef & $169.3 d$ & $149.3 \mathrm{~g}$ & $1319.6 \mathrm{e}$ & $747.2 \mathrm{e}$ & $1280.2 \mathrm{f}$ & $744.4 \mathrm{f}$ \\
\hline & $\mathrm{C} 4$ & $224.7 \mathrm{~b}$ & $156.8 \mathrm{~d}$ & $211.4 \mathrm{~b}$ & $165.6 \mathrm{~d}-\mathrm{f}$ & $1793.9 \mathrm{~b}$ & $884.4 \mathrm{~cd}$ & $1704.4 \mathrm{~b}$ & $927.2 \mathrm{c}$ \\
\hline $\mathrm{b}$ & & $51.0 *$ & $30.0 *$ & $48.9^{* *}$ & $33.4^{* *}$ & $380.3^{* *}$ & $174.8^{* *}$ & $375.9 * *$ & $188.8^{* *}$ \\
\hline $\mathrm{r}$ & & $0.95 *$ & $0.90 *$ & $0.98^{*}$ & $0.96^{* *}$ & $0.96^{* *}$ & $1.00^{* *}$ & $0.98^{* *}$ & $0.99 * *$ \\
\hline \multirow[t]{5}{*}{$\mathrm{D}$} & $\mathrm{CO}$ & $25.6 o p$ & $57.1 \mathrm{n}$ & $23.0 n$ & 53.4 no & $218.5 \mathrm{no}$ & $280.4 \mathrm{kl}$ & $178.8 \mathrm{o}$ & $275.9 \mathrm{kl}$ \\
\hline & $\mathrm{C} 1$ & $57.4 \mathrm{kl}$ & 52.6no & $46.8 \mathrm{kl}$ & $67.3 \mathrm{~m}$ & $487.0 \mathrm{k}$ & $307.1 \mathrm{j}-1$ & 486.21 & $231.81 \mathrm{~m}$ \\
\hline & $\mathrm{C} 2$ & $102.0 \mathrm{i}$ & 76.71 & $75.4 \mathrm{j}$ & $135.9 \mathrm{~h}$ & $808.4 \mathrm{~g}$ & $464.6 \mathrm{~h}$ & $612.7 \mathrm{i}$ & $473.2 \mathrm{gh}$ \\
\hline & $\mathrm{C} 3$ & $191.1 \mathrm{e}$ & 154.6de & $158.0 \mathrm{ef}$ & $160.8 \mathrm{f}$ & $1493.7 \mathrm{~d}$ & $782.5 \mathrm{e}$ & $1255.8 \mathrm{f}$ & $835.8 \mathrm{e}$ \\
\hline & $\mathrm{C} 4$ & $239.3 a$ & $168.4 \mathrm{c}$ & $229.4 a$ & $168.0 c-e$ & $1968.7 \mathrm{a}$ & $1035.3 b$ & $1945.8 \mathrm{a}$ & $1176.8 \mathrm{a}$ \\
\hline$b$ & & $56.1^{* *}$ & 32.5 * & $52.4^{* *}$ & $32.3 *$ & $450.7^{* *}$ & $198.5^{* *}$ & $430.4^{* *}$ & $240.6^{*}$ \\
\hline $\mathrm{r}$ & & $0.97^{* *}$ & $0.86^{*}$ & $0.94^{* *}$ & 0.91 * & $0.97^{* *}$ & $0.93^{* *}$ & $0.93 * *$ & 0.90 * \\
\hline
\end{tabular}


Table A8. Cont.

\begin{tabular}{|c|c|c|c|c|c|c|c|c|c|}
\hline \multirow{3}{*}{ Population } & \multirow{3}{*}{ Cycle } & \multicolumn{4}{|c|}{ DPPH } & \multicolumn{4}{|c|}{ TEAC } \\
\hline & & \multicolumn{4}{|c|}{ (mmol TE/100 g DW) } & \multicolumn{4}{|c|}{ (mmol TE/100 g DW) } \\
\hline & & E1 & E2 & E3 & E4 & E1 & E2 & E3 & E4 \\
\hline \multirow[t]{5}{*}{$\mathrm{E}$} & $\mathrm{CO}$ & $23.4 p$ & 51.1no & $24.6 n$ & $47.7 \mathrm{op}$ & 208.5 no & $201.4 \mathrm{~m}$ & 207.30 & $189.7 \mathrm{mn}$ \\
\hline & $\mathrm{C} 1$ & $50.2 \mathrm{~m}$ & $69.5 \mathrm{~m}$ & $46.2 \mathrm{kl}$ & 76.81 & $440.1 \mathrm{kl}$ & 270.91 & $324.7 n$ & $279.9 \mathrm{k}$ \\
\hline & $\mathrm{C} 2$ & $99.2 \mathrm{i}$ & $115.7 \mathrm{i}$ & 104.3gh & $104.0 \mathrm{j}$ & $755.5 \mathrm{~h}$ & $551.7 \mathrm{fg}$ & $590.1 \mathrm{ij}$ & $433.1 \mathrm{~h}$ \\
\hline & $\mathrm{C} 3$ & $164.1 \mathrm{~h}$ & $160.3 \mathrm{~d}$ & $174.0 \mathrm{~d}$ & 162.1ef & $1322.3 \mathrm{e}$ & $869.2 \mathrm{~d}$ & $1288.2 f$ & 865.3de \\
\hline & $\mathrm{C} 4$ & $212.0 \mathrm{c}$ & $179.8 \mathrm{~b}$ & $200.6 b c$ & $174.2 \mathrm{c}$ & $1687.2 \mathrm{c}$ & $1234.9 a$ & $1484.5 \mathrm{e}$ & $1183.4 a$ \\
\hline $\mathrm{b}$ & & $49.1^{* *}$ & $34.8^{* *}$ & $48.0^{* *}$ & $33.8^{* *}$ & $384.0 * *$ & $266.5^{* *}$ & $351.8^{* *}$ & $257.3^{* *}$ \\
\hline $\mathrm{r}$ & & $0.98^{* *}$ & $0.98^{* *}$ & $0.97^{* *}$ & $0.97 * *$ & $0.98^{* *}$ & $0.96^{* *}$ & $0.93^{* *}$ & $0.93^{* *}$ \\
\hline \multirow[t]{3}{*}{$\begin{array}{c}\text { Check } \\
\text { var. }\end{array}$} & KND & 139.4 & 116.1 & 137.5 & 130.7 & 1055.9 & 848.6 & 1066.4 & 953.3 \\
\hline & KGW & 98.5 & 70.5 & 88.2 & 90.2 & 791.4 & 374.3 & 627.1 & 465.3 \\
\hline & P339 & 14.3 & 14.2 & 14.3 & 9.2 & 104.2 & 92.4 & 108.0 & 91.7 \\
\hline
\end{tabular}

* and ** significant at 0.05 and 0.01 probability levels; ${ }^{1}$ means in a column followed by the same letter are not significantly different at 0.05 probability levels; $b$-response to selection; $r$-correlation coefficient; E1—Khon Kaen, dry season; E2-Khon Kaen, rainy season; E3-Uthai Thani, dry season; E4-Uthai Thani, rainy season.

\section{References}

1. Burt, A.J.; Caston, L.; Leeson, S.; Shelp, B.J.; Lee, E.A. Development and utilization of high carotenoid maize germplasm: Proof of concept. Crop Sci. 2013, 53, 554-563. [CrossRef]

2. Abdel-Aal, E.M.; Young, J.C.; Rabalski, I. Anthocyanin composition in black, blue, pink, purple, and red cereal grains. J. Agric. Food Chem. 2006, 54, 4696-4704. [CrossRef] [PubMed]

3. Khampas, S.; Lertrat, K.; Lomthaisong, K.; Suriharn, B. Variability in phytochemicals and antioxidant activity in corn at immaturity and physiological maturity stages. Int. Food Res. J. 2013, 20, 3149-3157.

4. Herrera-Sotero, M.Y.; Cruz-Hernández, C.D.; Trujillo-Carretero, C.; Rodríguez-Dorantes, M.; García-Galindo, H.S.; Chávez-Servia, J.L.; Oliart-Ros, R.M.; Guzmán-Gerónimo, R.I. Antioxidant and antiproliferative activity of blue corn and tortilla from native maize. Chem. Cent. J. 2017, 11, 1-8. [CrossRef]

5. Khamphasan, P.; Lomthaisong, K.; Harakotr, B.; Ketthaisong, D.; Scott, M.P.; Lertrat, K.; Suriharn, B. Genotypic variation in anthocyanins, phenolic compounds, and antioxidant activity in cob and husk of purple field corn. Agronomy 2018, 8, 271. [CrossRef]

6. Ghasemzadeh, A.; Karbalaii, M.T.; Jaafar, H.Z.E.; Rahmat, A. Phytochemical constituents, antioxidant activity, and antiproliferative properties of black, red, and brown rice bran. Chem. Cent. J. 2018, 12, 17-29. [CrossRef]

7. Isabelle, M.; Lee, B.L.; Lim, M.T.; Koh, W.P.; Huang, D.; Ong, C.N. Antioxidant activity and profiles of common fruits in Singapore. Food Chem. 2010, 123, 77-84. [CrossRef]

8. Nabae, K.; Hayashi, S.M.; Ichihara, T.; Hagiwara, A.; Tamano, S. A 90-day oral toxicity study of purple corn color, a natural food colorant, in F344 rats. Food Chem. Toxicol. 2008, 46, 774-780. [CrossRef]

9. Lao, F.; Sigurdson, G.T.; Giusti, M.M. Health benefits of purple corn (Zea mays L.) phenolic compounds. Compr. Rev. Food Sci. F 2017, 16, 234-246. [CrossRef]

10. Anderson, E.G. Pericarp studies in maize: II. The allelomor- phism of a series of factors for pericarp color. Genetics 1924, 9, 442-453.

11. Coe, E.H.; Neuffer, M.G.; Hoisingto, D.A. The genetics of corn. In Corn and Corn Improvement; Sprague, G.F., Dudlley, J., Eds.; ASA: Madison, WI, USA, 1988; pp. 81-258.

12. Goettel, W.; Messing, J. Divergence of gene regulation through chromosomal rearrangements. BMC Genom. 2010, 11, 678. [CrossRef] [PubMed]

13. Robbins, M.L.; Wang, P.; Sekhon, R.S.; Chopra, S. Gene structure induced epigenetic modifications of pericarp color1 alleles of maize result in tissue-specific mosaicism. PLoS ONE. 2009, 4, 1-12. [CrossRef]

14. Chopra, S.; Athma, P.; Li, X.G.; Peterson, T. A maize Myb homolog is encoded by a multicopy gene complex. Mol. Gen. Genet. 1998, 260, 372-380. [CrossRef]

15. Zhang, F.; Peterson, T. Comparisons of maize pericarp color1 alleles reveal paralogous gene recombination and an organ-specific enhancer region. Plant Cell 2005, 17, 903-914. [CrossRef] [PubMed]

16. Landi, P.; Cane, M.A.; Frascaroli, E. Responses to divergent selection for cob color in maize. Euphytica 2008, 164, 645-658. [CrossRef] 
17. Samanta, A.K.; Senani, S.; Kolte, A.P.; Sridhar, M.; Sampath, K.T.; Jayapal, N.; Devi, A. Production and in vitro evaluation of xylooligosaccharides generated from corn cobs. Food Bioprod Process 2012, 90, 466-474. [CrossRef]

18. Wachirapakorn, C.; Pilachai, K.; Wanapat, M.; Pakdee, P.; Cherdthong, A. Effect of ground corn cobs as a fiber source in total mixed ration on feed intake, milk yield and milk composition in tropical lactating crossbred Holstein cows. Anim. Nutr. 2016, 2, 334-338. [CrossRef]

19. Chen, M.; Xia, L.; Xue, P. Enzymatic hydrolysis of corn cob and ethanol production from cellulosic hydrolysate. Int. Biodeterior Biodegrad 2007, 59, 85-89. [CrossRef]

20. Ji, Z.; Lin, H.; Chen, Y.F.; Dong, Y.B.; Imran, M. Corn cob modified by lauric acid and ethanediol for emulsified oil adsorption. J. Cent. South Univ. T 2015, 22, 2096-2105. [CrossRef]

21. Hosoda, K.; Eruden, B.; Matsuyama, H.; Shioya, S. Effect of anthocyanin-rich corn silage on digestibility, milk production and plasma enzyme activities in lactating dairy cows. Anim. Sci. J. 2012, 83, 453-459. [CrossRef]

22. Khonkhaeng, B.; Cherdthong, A. Pleurotus ostreatus and Volvariella volvacea can enhance the quality of purple field corn stover and modulate ruminal fermentation and feed utilization in tropical beef cattle. Animals 2019, 9, 1084. [CrossRef] [PubMed]

23. Li, C.Y.; Kim, H.W.; Won, S.R.; Min, H.K.; Park, K.J.; Park, J.Y.; Ahn, M.S.; Rhee, H.I. Corn husk as a potential source of anthocyanins. J. Cent. South Univ. T 2008, 56, 11413-11416. [CrossRef] [PubMed]

24. Yang, Z.; Zhai, W. Identification and antioxidant activity of anthocyanins extracted from the seed and cob of purple corn (Zea mays L.). Innov. Food Sci. Emerg. Technol. 2010, 11, 169-176. [CrossRef]

25. Simla, S.; Boontang, S.; Harakotr, B. Anthocyanin content, total phenolic content, and antiradical capacity in different ear components of purple waxy corn at two maturation stages. AJCS 2016, 10, 675-682. [CrossRef]

26. Fehr, W.R. Principles of Cultivar Development: Theory and Technique; Macmillan: New York, NY, USA, 1987.

27. De Leon, N.; Coors, J.G. Twenty-four cycle of mass selection for prolification in the Golden Glow maize population. Crop Sci. 2002, 42, 325-333. [CrossRef]

28. De Galarreta, J.I.R.; Álvarez, A. Short communication: Divergent mass selection for different flowering times in a Spanish synthetic maize population. Span, J. Agric. Res. 2008, 6, 56-60. [CrossRef]

29. Hallauer, A.R.; Carena, M.J.; Miranda-Filho, J.B. Quantitative Genetics in Maize Breeding; Springer: New York, NY, USA, 2010.

30. Kesornkeaw, P.; Lertrat, K.; Suriharn, B. Response to four cycles of mass selection for prolificacy at low and high population densities in small ear waxy corn. Asian, J. Plant Sci. 2009, 8, 425-432. [CrossRef]

31. Senamontry, K.; Lertrat, K.; Suriharn, B. Response to five cycles of modified mass selection for ear length in waxy corn. Sabrao, J. Breed. Genet. 2013, 45, 332-340.

32. Hussanun, S.; Bhalang, S.; Lertrat, K. Yield and early maturity response to four cycles of modified mass selection in purple waxy corn. Turk. J. Field Crops 2014, 19, 84-89. [CrossRef]

33. Dudley, J.W.; Lambert, R.J. 100 generations of selection for oil and protein in corn. Plant Breed. Rev. 2004, 24, 79-110. [CrossRef]

34. Scott, M.P.; Darrigues, A.; Stahly, T.S.; Lamkey, K. Recurrent selection to alter grain methionine concentration and improve nutritional value of maize. Crop Sci. 2008, 48, 1705-1713. [CrossRef]

35. Preciado-Ortiz, R.E.; García-Lara, S.; Ortiz-Islas, S.; Ortega-Corona, A.; Serna-Saldivar, S.O. Response of recurrent selection on yield, kernel oil content and fatty acid composition of subtropical maize populations. Field Crops Res. 2013, 142, 27-35. [CrossRef]

36. Dhliwayo, T.; Palacios-Rojas, N.; Crossa, J.; Pixley, K.V. Effects of S1 recurrent selection for provitamin A carotenoid content for three open-pollinated maize cultivars. Crop Sci. 2014, 54, 2449-2460. [CrossRef]

37. Jing, P.; Noriega, V.; Schwartz, S.J.; Giusti, M.M. Effects of growing conditions on purple corncob (Zea mays L.) anthocyanins. J. Agr. Food Chem. 2007, 55, 8625-8629. [CrossRef]

38. Yang, Z.; Fan, G.; Gu, Z.; Han, Y.; Chen, Z. Optimization extraction of anthocyanins from purple corn (Zea mays L.) cob using tristimulus colorimetry. Eur. Food Res. Technol. 2008, 227, 409-415. [CrossRef]

39. Lee, J.; Durst, R.W.; Wrolstad, R.E. Determination of total monomeric anthocyanin pigment content of fruit juices, beverages, natural colorants, and wines by the $\mathrm{pH}$ differential method: Collaborative study. J. AOAC Int. 2005, 88, 1269-1278. [CrossRef]

40. Hu, Q.P.; Xu, J.G. Profiles of carotenoids, anthocyanins, phenolics, and antioxidant activity of selected color waxy corn grains during maturation. J. Agric. Food Chem. 2011, 59, 2026-2033. [CrossRef] 
41. Gomez, K.A.; Gomez, A.A. Statistical Procedure for Agricultural Research; John Wiley \& Sons: New York, NY, USA, 1984.

42. Holland, J.B.; Nyquist, W.E.; Cervartes-Martinez, C.T. Estimating and interpreting heritability for plant breeding: An update. Plant Breed. Rev. 2003, 22, 2-112.

43. Abakemal, D.; Shimelis, H.; Derera, J. Analyses of combining ability and genotype-by-environment interaction of quality protein maize inbred lines adapted to tropical-highlands. Crop Sci. 2016, 56, 3078-3089. [CrossRef]

44. Badu-Apraku, B.; Menkir, A.; Ajala, S.; Akinwale, R.; Oyekunle, M.; Obeng-Antwi, K. Performance of tropical early-maturing maize cultivars in multiple stress environments. Can. J. Plant Sci. 2010, 90, 831-852. [CrossRef]

45. Khampas, S.; Lertrat, K.; Lomthaisong, K.; Simla, S.; Suriharn, B. Effect of location, genotype and their interactions for anthocyanins and antioxidant activities of purple waxy corn cob. Turk, J. Field Crops 2015, 20, 15-23. [CrossRef]

46. Mohamed, G.; Lertrat, K.; Suriharn, B. Phenolic compound, anthocyanin content, and antioxidant activity in some parts of purple waxy corn across maturity stages and locations. Int. Food Res. J. 2017, 24, 490-497.

47. Baron, V.S.; Najda, H.G.; Stevenson, F.C. Influence of population density, row spacing and hybrid on forage corn yield and nutritive value in a cold-season environment. Can. J. Plant Sci. 2006, 86, 1131-1138. [CrossRef]

48. Tollenaar, M.; Daynard, T.B.; Hunter, R.B. Effect of temperature on rate of leaf appearance and flowering date in maize. Crop Sci. 1979, 19, 363-366. [CrossRef]

49. Harakotr, B.; Suriharn, B.; Scott, M.P.; Lertrat, K. Genotypic variability in anthocyanins, total phenolics, and antioxidant activity among diverse waxy corn germplasm. Euphytica 2015, 203, 237-248. [CrossRef]

50. Mahan, A.L.; Murray, S.C.; Rooney, L.W.; Crosby, K.M. Combining ability for total phenols and secondary traits in a diverse set of colored (red, blue, and purple) maize. Crop Sci. 2013, 53, 1248-1255. [CrossRef]

51. Menkir, A.; Liu, W.; White, W.S.; Maziya-Dixon, B.; Rocheford, T. Carotenoid diversity in tropical-adapted yellow maize inbred lines. Food Chem. 2008, 109, 521-529. [CrossRef]

52. Sandoya, G.; Butrón, A.; Santiago, R.; Alvarez, A.; Malvar, R.A. Indirect response to selection for improving resistance to the Mediterranean corn borer (Sesamia nonagrioides Lef) in maize. Euphytica 2010, 176, $231-237$. [CrossRef]

53. Lamkey, C. Selection and Genetic Drift in North American Maize. Ph.D. Thesis, University of Nebraska, Lincoln, Nebraska, 2014.

54. Rodríguez, V.M.; Soengas, P.; Landa, A.; Ordás, A.; Revilla, P. Effects of selection for color intensity on antioxidant capacity in maize (Zea mays L.). Euphytica 2013, 193, 339-345. [CrossRef]

55. Chen, S.M.; Coe, E.H. Control of anthocyanin synthesis by the C locus in maize. Biochem. Genet. 1977, 15, 333-346. [CrossRef]

56. Coe, E.H. Anthocyanin genetics. In The Maize Handbook; Freeling, M., Walbot, V., Eds.; Springer: New York, NY, USA, 1994; pp. 279-281.

57. Styles, E.D.; Ceska, O. Pericarp flavonoids in genetic strains strains of Zea mays. Maydica 1989, 34, $227-237$.

58. Dar, Z.A.; Lone, A.A.; Alaie, B.A.; Ali, G.; Gazal, A.; Gulzar, S.; Yousuf, N. Correlation studies in temperate maize (Zea mays L.) inbred lines. Plant Arch. 2015, 15, 1191-1194.

59. Tiwari, D.T.; Tripathi, S.R.; Tripathi, M.P.; Khatri, N.; Bastola, B.R. Genetic variability and correlation coefficients of major traits in early maturing rice under rainfed lowland environments of Nepal. Adv. Agric. 2019, 1-9. [CrossRef]

60. Sowmy, H.H.; Brunda, S.M.; Shinde, D.G.; Gowda, V.; Kamatar, M.Y. Estimation of correlation coefficients and path for yield traits in grain mold tolerant $\mathrm{f} 3$ progenies of sorghum. Int. J. Sci. Res. 2013, 4, 1420-1424.

61. Govindaraj, M.; Selvi, B.; Rajarathinam, S. Correlation studies for grain yield components and nutritional quality traits in pearl millet (Pennisetum glaucum (L.) R. Br.) Germplasm. World, J. Agric. Sci. 2009, 5, 686-689.

62. Pairochteerakul, P.; Jothityangkoon, D.; Ketthaisong, D.; Simla, S.; Lertrat, K.; Suriharn, B. Seed germination in relation to total sugar and starch in endosperm mutant of sweet corn genotypes. Agronomy 2018, 8, 299. [CrossRef]

63. Bello, O.B.; Abdulmaliq, S.Y.; Ige, S.A.; Mahamood, J.; Oluleye, F.; Azeez, M.A.; Afolabi, M.S. Evaluation of early and late/intermediate maize varieties for grain yield potential and adaptation to a southern guinea savanna agro-ecology of Nigeria. Int. J. Plant Res. 2012, 2, 14-21. [CrossRef] 
64. Grzybowski, M.; Adamczyk, J.; Jończyk, M.; Sobkowiak, A.; Szczepanik, J.; Frankiewicz, K.; Fronk, J.; Sowiński, P. Increased photosensitivity at early growth as a possible mechanism of maize adaptation to cold springs. J. Exp. Bot. 2019, 70, 2887-2904. [CrossRef]

65. Manjeru, P. The Influence of Abiotic Stress on CIMMYT Provitamin a Elite Maize Germplasm. Ph.D. Thesis, University of the Free State, Bloemfontein, South Africa, 2017.

66. Sangoi, L. Understanding plant density effects on maize growth and development: An important issue to maximize grain yield. Cienc. Rural 2000, 31, 159-168. [CrossRef]

67. Onasanya, R.O.; Aiyelari, O.P.; Onasanya, A.; Oikeh, S.; Nwilene, F.E.; Oyelakin, O.O. Growth and yield response of maize (Zea mays L.) to different rates of nitrogen and phosphorus fertilizers in southern Nigeria. World J. Agric. Sci. 2009, 5, 400-407.

68. Immanuel, R.; Thiruppathi, M.; Sudhagar Rao, G.B.; Saravanaperumal, M.; Nambi, J. Soil moisture, crop growth and yield of maize as influenced by Albizia saman agroforestry system. IJRAR 2019, 6, 327-334.

69. Chandler, K.; Lipka, A.E.; Owens, B.F.; Li, H.; Buckler, E.S.; Rocheford, T.; Gore, M.A. Genetic analysis of visually scored orange kernel color in maize. Crop Sci. 2012, 53, 189-200. [CrossRef]

70. Owens, B.F.; Mathew, D.; Diepenbrock, C.H.; Tiede, T.; Wu, D.; Mateos-Hernandez, M.; Gore, M.A.; Rocheford, T. Genome-wide association study and pathway-level analysis of kernel color in maize. G3 2019, 9, 1945-1955. [CrossRef] [PubMed]

71. Khoo, H.E.; Azlan, A.; Tang, S.T.; Lim, S.M. Anthocyanidins and anthocyanins: Colored pigments as food, pharmaceutical ingredients, and the potential health benefits. Food Nutr. Res. 2017, 6, 1-21. [CrossRef] [PubMed]

72. Lin, D.; Xiao, M.; Zhao, J.; Li, Z.; Xing, B.; Li, X.; Kong, M.; Li, L.; Zhang, Q.; Liu, Y.; et al. An overview of plant phenolic compounds and their importance in human nutrition and management of type 2 diabetes. Molecules 2016, 21, 1374. [CrossRef]

73. Siyuan, S.; Tong, L.; Liu, R. Corn phytochemicals and their health benefits. Food Sci. Hum. Wellness 2018, 7, 185-195. [CrossRef]

(C) 2020 by the authors. Licensee MDPI, Basel, Switzerland. This article is an open access article distributed under the terms and conditions of the Creative Commons Attribution (CC BY) license (http://creativecommons.org/licenses/by/4.0/). 